\author{
UNIVERSIDADE FEDERAL DO ESPÍRITO SANTO \\ CENTRO DE EDUCAÇÃO \\ PROGRAMA DE PÓS-GRADUAÇÃO EM EDUCAÇÃO \\ MESTRADO EM EDUCAÇÃO
}

Aline de Menezes Bregonci

ESTUDANTES SURDOS NO PROEJA: O QUE NOS CONTAM AS NARRATIVAS SOBRE OS SEUS PERCURSOS 
Aline de Menezes Bregonci

\title{
ESTUDANTES SURDOS NO PROEJA: O QUE NOS CONTAM AS NARRATIVAS SOBRE OS SEUS PERCURSOS
}

\author{
Dissertação apresentada ao \\ Programa de Pós-Graduação em \\ Educação, do Centro de Educação, \\ da Universidade Federal do Espírito \\ Santo, como requisito parcial para \\ obtenção do título de Mestre em \\ Educação, na área de concentração \\ Diversidade e Práticas Educacionais \\ Inclusivas \\ Orientadora: Prof $^{a}$ Dr $^{\mathrm{a}}$ Edna Castro \\ de Oliveira
}


Ficha Catalográfica

Dados Internacionais de Catalogação-na-publicação (CIP) (Biblioteca Central da Universidade Federal do Espírito Santo, ES, Brasil)

Bregonci, Aline de Menezes, 1980-
B833e $\quad$ Estudantes surdos no PROEJA : o que nos contam as
narrativas sobre os seus percursos / Aline de Menezes Bregonci.
-2012.

$178 \mathrm{f}$.

Orientadora: Edna Castro de Oliveira.

Dissertação (Mestrado em Educação) - Universidade Federal do Espírito Santo, Centro de Educação.

1. Surdos - Educação. 2. Educação do adolescente. 3. Educação de adultos. 4. Ensino profissional. 5. Narrativa (Retórica). I. Oliveira, Edna Castro de, 1950-. II. Universidade Federal do Espírito Santo. Centro de Educação. III. Título. 


\section{Aline de Menezes Bregonci}

\section{ESTUDANTES SURDOS NO PROEJA: O QUE NOS CONTAM AS NARRATIVAS SOBRE OS SEUS PERCURSOS}

Dissertação apresentada ao Programa de Pós-Graduação em Educação, do Centro de Educação, da Universidade Federal do Espírito Santo, como requisito parcial para obtenção do título de Mestre em Educação, na área de concentração Diversidade e Práticas Educacionais Inclusivas

Aprovada em

Comissão Examinadora

Prof $^{\mathrm{a}} \mathrm{Dr}^{\mathrm{a}}$ Edna Castro de Oliveira

Universidade Federal do Espírito Santo Orientadora

Prof $^{\mathrm{a}} \mathrm{Dr}^{\mathrm{a}}$ Ivone Martins de Oliveira

Universidade Federal do Espírito Santo

Prof $^{\underline{a}}$ Dr $^{\underline{a}}$ Maria Aparecida Santos Corrêa Barreto

Universidade Federal do Espírito Santo

Prof ${ }^{\mathrm{a}}$ Dr ${ }^{\mathrm{a}}$ Adriana da Silva Thoma

Universidade Federal do Rio Grande do Sul 
A mim e a todos que me auxiliaram durante este percurso 


\section{Agradecimentos}

Quero começar agradecendo a minha querida orientadora Prof ${ }^{\mathrm{a}}$. Dr ${ }^{\mathrm{a}}$ Edna Castro de Oliveira, pelas orientações, conversas e pela parceria. Muito obrigada pela sua confiança em mim!

As professoras Ivone Martins de Oliveira e Maria Aparecida Santos Corrêa Barreto, que carinhosamente aceitaram participar da minha banca, muito obrigada por terem participado desde a qualificação até a defesa.

A professora Adriana da Silva Thoma, que se deslocou do Rio Grande do Sul até aqui para participar da minha banca. Muito obrigada, não só por vir, mas também por ser umas das inspirações teóricas deste trabalho.

Aos meus queridos amigos: Lucyenne Vieira-Machado, Leonardo Vieira-Machado, Keli Simões Xavier, Keila Cardoso Teixeira, Jeferson Moreira Santana e Jaqueline Anhert, trocando com vocês tudo fica mais fácil.

Aos companheiros do mestrado: Helton Canhamaque, Kênia Tinelli, Custódio Jovêncio e Edna Scopel . Obrigada pela parceria!

Aos amigos do grupo de estudo: Tatiana Santana, Dalva Mendes e Eliéser Zen, que tanto contribuíram para muitas discussões teóricas que utilizo ao longo deste trabalho.

Aos companheiros de trabalho das EMEF's - João Paulo II, Martim Lutero e Sebastião Rodrigues Sobrinho.

A todos os participantes da pesquisa que gentilmente me contaram seus percursos. Muito obrigada! 
Aos meus familiares, que nos bastidores me deram a sustentação necessária para chegar ao fim de mais esta etapa da vida acadêmica.

E a todos os surdos e ouvintes que tem se movimentado para construir uma educação pública, gratuita e de qualidade para os estudantes surdos, sejam eles crianças, jovens ou adultos. A nossa luta é a motivação que propulsionou a existência dessa pesquisa! 
"O amanhã é uma possibilidade que precisamos de trabalhar e por que, sobretudo, temos de lutar para construir". (Paulo Freire - Pedagogia da Indignação) 


\section{Resumo}

A presente dissertação: "Estudantes Surdos no Proeja: o que nos contam as narrativas sobre os seus percursos?", problematiza os caminhos trilhados pelos estudantes surdos jovens e adultos no Instituto Federal de Educação, Ciência e Tecnologia do Espírito Santo - Ifes, dentro do Programa Nacional de Integração da Educação Profissional com a Educação Básica na Modalidade de Educação Jovens e Adultos- Proeja, procurando através das narrativas, remontar esses percursos e a partir deles, procurar responder algumas questões. O interesse por este tema surgiu devido aos últimos movimentos nos quais a comunidade surda se engajou, a fim de tentar estabelecer uma política em nível nacional que garanta 0 acesso e a permanência dos surdos na escola. Esta dissertação tem como objetivo geral evidenciar os espaços de formação que os surdos tem ocupado e como tem sido esse processo de formação para o mundo do trabalho. Como objetivos específicos, destacamos: a) a realização de um resgate histórico da Educação de Surdos; b) a discussão de questões legais, relacionadas ao direito educacional do surdos; c) a identificação de espaços nos quais ocorrem o diálogo entre a Educação de Jovens e Adultos, a Educação de Surdos e a Educação Profissional e Tecnológica; d) apontar algumas possibilidades de alternativas para o desenvolvimento dos surdos e a sua inserção no mundo do trabalho. Como inspirações teóricas utilizamos Bakhtin, Benjamin, Ricouer, Freire e Marx, estes são nossas referências principais. Na metodologia de trabalho, lançamos mão da Narrativa, como forma de alcançar os participantes do processo de inclusão dos surdos no lfes. Primeiramente, remontamos o passado da Educação de Surdos, como forma de levantar dados sobre o que nos dizem as fontes bibliográficas, sobre esse processo. Em seguida, damos ênfase a uma discussão legal, que procura, dentro da legislação, subsídios que garantam aos surdos uma formação para o mundo do trabalho. Por último, construímos os percursos dos estudantes surdos dentro do lfes, destacando o movimento que surgiu dentro do instituto por conta da inclusão desses alunos, problematizando as práticas e refletindo sobre os fatos que se deram ao longo desta caminhada. Foram muitos os acontecimentos, verdadeiras movimentações, que 
merecem nossa reflexão, pois a experiência ali vivenciada, tem muito a contribuir para pensarmos sobre como, no futuro, garantir a outros estudantes surdos, condições de acesso e permanência, não só no lfes, mas nas escolas como um todo. E também, destacamos uma outra alternativa de trabalho com surdos, no que tange a EJA e a formação para o mundo trabalho que é a EJA da Garoto, um espaço onde foi possível dialogar com outros surdos que almejam a formação profissional, conhecer quais são seus projetos de vida e perspectivas profissionais.

Palavras-Chaves: Educação de Surdos, EJA, EPT e Narrativas 


\section{Abstract}

The present study, "Deaf Students in Proeja :what do the narratives tell us about their journeys?", discusses the paths taken by young or adult deaf students at IFES, the Federal Institute of Education, Science and Technology of the State of Espírito Santo, which occurred within the Proeja, the National Program for the Integration of Vocational with Basic Education in the Modality of Youth and Adult Education. This paper aimed to trace these journeys through the narratives and from them look for answering some questions. The interest in this subject came up due to recent movements in which the deaf community has been engaged in order to establish a national policy that ensures access and permanence of the deaf students in the school. This study also aims to highlight the educational places where the deaf have been occupying and how this training process has been for the labor market. As the specific aims of this paper we highlighted the following topic: a) the realization of a historical review of the Deaf Education; b) the discussion of legal issues related to the right of deaf education; $c$ ) the identification of the places in which occurred the dialogue among the Youth and Adult Education, the Education of the Deaf and the Technological and Professional Education; d) to point out some possible alternatives for the development of the deaf and their integration into the labor market. We used the narratives as the methodology of this study in order to involve the participants in the process of including the deaf people at IFES. First, we traced the history of the Deaf Education as a way to collect data concerning what the bibliographic sources tell us about this process. Then, we present a legal discussion that intends to find, within the law, subsidies to ensure that deaf have access to an education that considers the labor market. Finally, we traced the paths of deaf students in the Federal Institute of Espírito Santo, highlighting the movements that emerged within the institute due to the inclusion of these students. We also questioned the practices in this process and we reflected over the events that occurred along this walk. There were many events, happenings, real movements that deserve our reflection because the experience lived there has a lot to contribute, mainly on ways to ensure that other 
deaf students have access not only at IFES but in every school. And also, we point another working alternative with deaf people, concerning to the EJA and the training to the world that is the work of EJA Garoto, a space where we can talk with other deaf people who want professional training, to know what are their life projects and career prospects.

Key Words: Education of deaf students, EJA, EPT and Narratives. 


\section{Lista de Siglas}

AEE - Atendimento Educacional Especializado

CNE - Conselho Nacional de Educação

CONAE - Conferência Nacional de Educação

EJA - Educação de Jovens e Adultos

EPT - Educação Profissional e Tecnológica

FENEIDA - Federação Nacional de Educação e Integração dos Deficientes Auditivos FENEIS - Federação Nacional de Educação e Integração dos Surdos

GES - Grupo de Estudos Surdos

IFES - Instituto Federal de Educação, Ciência e Tecnologia do Espírito Santo

INES - Instituto Nacional de Educação de Surdos

LIBRAS - Língua Brasileira de Sinais

LDBEN - Lei de Diretrizes e Bases da Educação Nacional

LS - Língua de Sinais

MEC - Ministério da Educação

NEE - Necessidades Educacionais Especiais

PNE - Plano Nacional de Educação

PROEJA - Programa Nacional de Integração da Educação Profissional com a Educação Básica na Modalidade de Jovens e Adultos

UFES - Universidade Federal do Espírito Santo

UFG - Universidade Federal de Goiás

UFSC - Universidade Federal de Santa Catarina 


\section{Sumário}

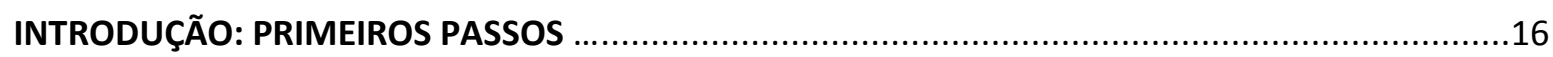

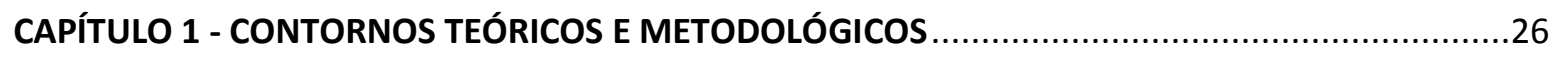

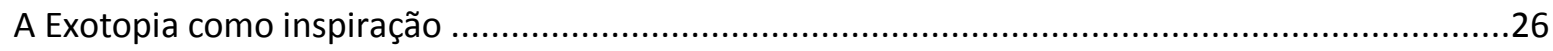

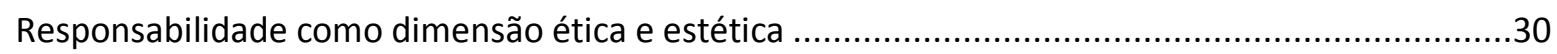

Notas bakhtinianas sobre a dialogia em pesquisa histórico-cultural.............................................34

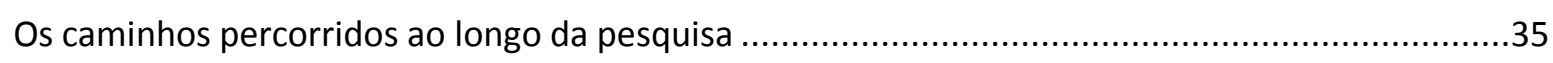

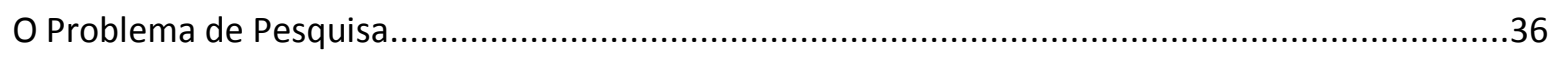

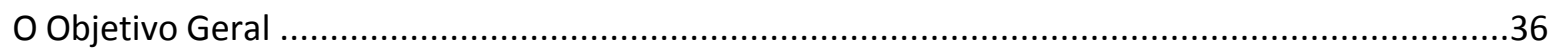

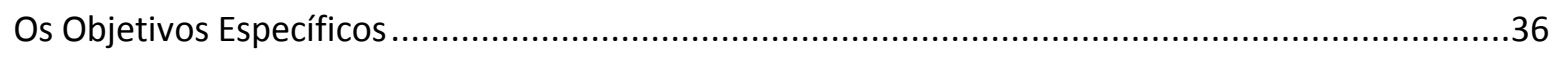

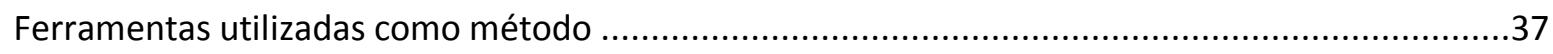

Benjamin, Ricouer e Bakhtin: inspirações para o trabalho de transcrição e tradução das narrativas.

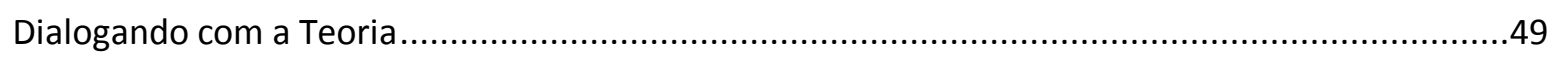

CAPÍTULO 2 - TODO POVO TEM HISTÓRIA: A HISTÓRIA DOS SURDOS COMO PONTO DE PARTIDA

A História da Educação de Surdos: o contexto europeu ...............................................................63

A História da educação de surdos no Brasil .............................................................................72

A História da Educação de Surdos no Espírito Santo ...............................................................79

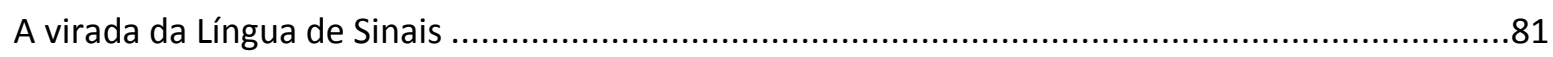

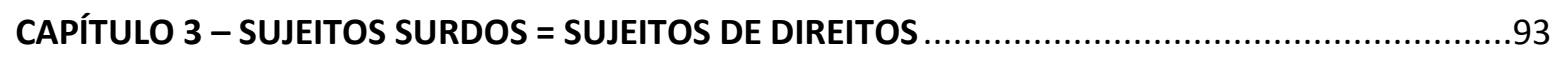

Os compromissos internacionais e o direito à educação ...........................................................94

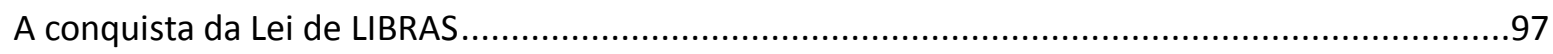

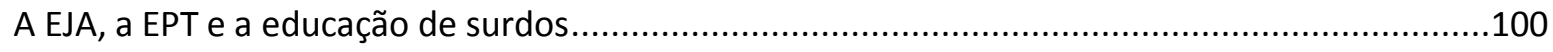

CAPÍTULO 4 - A INCLUSÃO DOS SURDOS NO PROEJA: COMO OS NARRADORES CONTAM ESSA

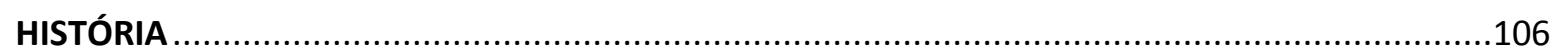

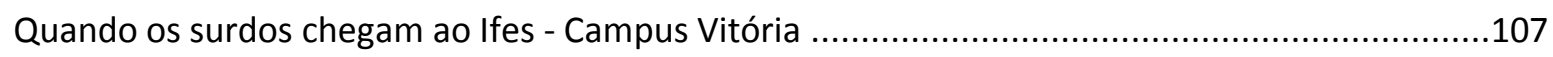

Sinalizando as experiências docentes no Campus Vitória.......................................................117

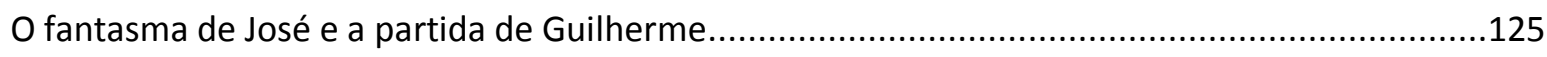

A segunda etapa: a chegada do surdo no Campus Serra .........................................................128

A partida de Rafael e suas marcas deixadas no Ifes - Campus Serra ...........................................145 
CAPÍTULO V - PROJETOS DE VIDA A PARTIR DO RETORNO À ESCOLA - A EJA COMO POSSIBILIDADE 


\section{INTRODUÇÃO: PRIMEIROS PASSOS ...}

Todo pesquisador parte de um ponto. Os eixos Educação de Surdos, Educação de Jovens e Adultos e Educação Profissional, serão os espaços nos quais transitarei na tentativa de tecer alguns argumentos e de onde buscarei trazer à tona implicações diversas acerca do sujeito surdo enquanto ser histórico e social. Contudo, esta caminhada teve como ponto de partida, outros momentos vividos e os sentidos produzidos em mim por essas discussões que especificamente, deixaram-me alerta e curiosa.

Penso que é de suma importância contextualizar o leitor sobre os sentidos que essas áreas que me proponho estudar produzem em minha vida, e de que forma 0 encontro com elas aconteceu. Afinal, sendo professora, são muitos os temas instigantes, presentes no cotidiano das escolas que poderiam me motivar para a pesquisa, contudo, a escolha pela surdez e a Educação de Jovens e Adultos tem uma explicação que transcende minhas relações profissionais com a escola e se entrecruzam em momentos da minha vida, muitos anos antes da minha entrada na universidade e do início da minha carreira no magistério.

Gostaria primeiramente de focar o meu encontro com os surdos, que se dá, ainda na minha infância. Através de amizades tecidas na escola, com colegas de sala que eram surdos, e que ao longo dos anos, foram sendo potencializadas através do fortalecimento dessas amizades e da agregação de outros tantos amigos e alunos surdos, me proporcionaram não só amizades e relações profissionais, mas a imersão no mundo dos surdos, sua cultura e sua língua.

Olíver Sácks, em seu livro Vendo Vozes (1998) apresenta a sua própria saga de imersão nesse mundo dos surdos, e é dele que eu me aproprio desse conceito de imersão e viagem ${ }^{1}$ a um mundo até então desconhecido e que passei a encarar não

1 O escritor americano utiliza o termo viagem empregado de duas formas. A primeira no sentido de viajar para lugares onde a população surda era significativamente numerosa e o uso da língua de sinais era corrente. E a 
como um grupo socialmente discriminado por sua "condição surda", ou o seu "não escutar", mas pela via de uma relação social diferenciada que alcança níveis de interação social intensos, através de seus traços culturais e línguísticos, assim como nós, ouvintes, o fazemos através da nossa língua.

Quando menciono a importância da língua nestas primeiras palavras, penso que é neste espaço que a cultura surda se mostra com mais propriedade, no uso e no exercício da língua de sinais. O mais intrigante disso tudo é pensar que eu estava ali o tempo todo sem saber que existia uma cultura surda e que o fato de estar ali tinha ligação apenas com as relações afetivas que eu havia construído com aqueles sujeitos e que por gostar deles enquanto pessoas, mais precisamente como amigos, é que aprendi a sua língua.

Isso tudo aconteceu no início da década de 1990, quando ainda era uma menina, num momento em que jamais passaria pela minha cabeça que um dia trabalharia com essa língua e enxergaria seus "falantes" como estrangeiros. Era simplesmente um ato de "balançar as mãos" e nos entendíamos mutuamente.

Nessa relação de amizade, constitui meu acesso à comunidade surda, conheci seus sujeitos e compreendi suas lutas. Vi naquelas pessoas o apreço que eles tinham por sua língua e como eles ficavam felizes quando descobriam que eu também falava sua língua. Mais uma vez, aponto a língua de sinais como sendo a marca ícone desta cultura. Falar sobre os surdos sem falar da sua língua é como ouvir a voz de Cassandra amaldiçoada por Apolo² ${ }^{2}$ é como profecia sem credibilidade.

Assim, compreender a dimensão do valor da Língua de Sinais para os surdos seja talvez estender a essa língua a mesma compreensão apaixonada que Olavo Bilac tem pela nossa Língua Portuguesa ${ }^{3}$, quando ele diz:

segunda no sentido de viajar pelo "mundo dos surdos", no sentido cultural.

2 Na mitologia grega, Cassandra era uma profetiza, contudo quando se negou a deitar-se com Apolo, foi amaldiçoada a ter todas as suas previsões vistas sem credibilidade.

3 Poesia extraída do site www.releituras.com/olavobilac, em 03/05/2011, às 12:02h 
Língua portuguesa Última flor do Lácio, inculta e bela, És, a um tempo, esplendor e sepultura:

Ouro nativo, que na ganga impura A bruta mina entre os cascalhos vela...

Amo-te assim, desconhecida e obscura.

Tuba de alto clangor, lira singela, Que tens o trom e o silvo da procela,

E o arrolo da saudade e da ternura!

Amo o teu viço agreste e o teu aroma De virgens selvas e de oceano largo! Amo-te, ó rude e doloroso idioma,

em que da voz materna ouvi: "meu filho!", E em que Camões chorou, no exílio amargo, O gênio sem ventura e o amor sem brilho!

Assim, apaixonados como Bilac, os surdos me contaminaram com esse sentimento, que de forma natural, fez com que me apropriasse de sua língua, sem levar em conta, que um dia, isso fosse me motivar para a pesquisa. Acredito que, essa motivação tem a ver com os meus dois outros encontros mencionados no início, com a educação e mais propriamente com a educação de jovens e adultos.

Dando continuidade a minha trajetória, quando ingressei na universidade, em 1998, mais precisamente, no curso de História, não pensava exatamente em ser professora, até o dado momento em que pisei na sala de aula. Talvez as condições de trabalho, não eram e nem são, até hoje, aquelas idealizadas por alguém. Contudo, a possibilidade de dialogar na dimensão de Freire (1993), com a possibilidade de produção e troca de conhecimentos, fez com que eu me identificasse e realmente produzisse em mim o ser professora. Assim compreendo que tive nesse momento, o meu encontro com a educação. $E$ faço questão de ressaltar que a comunidade onde iniciei meus trabalhos há dez anos atrás, é a mesma onde me encontro atualmente, ou seja, fiz e faço questão de dar continuidade ao diálogo, pois assim como Freire, entendo que é no diálogo que os homens e mulheres narram e constroem as suas histórias.

Sobre esse diálogo, trago ainda as contribuições de Zitkoski(2010), que desenvolve 
este conceito em Freire, colocando o diálogo como o ponto de partida para o pensamento crítico-problematizador.

\begin{abstract}
Nessa perspectiva, o diálogo é a força que impulsiona o pensar críticoproblematizador em relação à condição humana no mundo. Através do diálogo podemos dizer o mundo segundo nosso modo de ver. Além disso, o diálogo implica uma práxis social, que é o compromisso entre a palavra dita e nossa ação humanizadora. Essa possibilidade abre caminhos para repensar a vida em sociedade, discutir sobre nosso ethos cultural, sobre nossa educação, a linguagem que praticamos e a possibilidade de agirmos de outro modo de ser, que transforme o mundo que nos cerca. (p.117)
\end{abstract}

Assim, situo a minha prática diária de sala de aula nesse discurso, tentando fazer um pouco daquilo que acredito, dando ênfase a produção diária de conhecimento feita através dessa prática da dialogicidade.

Nesse percurso, em 2006, tive a oportunidade de cursar uma Especialização em Língua Brasileira de Sinais, na qual entrei em contato, pela primeira vez, com bibliografias que falavam desse sujeito surdo, que se referiam de forma científica e sistemática a um conjunto de práticas específicas para o uso dessa língua. Tudo isso para mim foi uma grande surpresa, isso porque, nunca tinha parado para pensar sobre a Língua de Sinais sob esses aspectos.

A conclusão desta Especialização me proporcionou a entrada na Prefeitura Municipal de Vila Velha através de concurso púbico, em 2007, onde passei a atuar como professora bilíngue. Pela primeira vez unia meus conhecimentos de forma sistematizada para a prática de sala de aula. Neste papel, deveria concentrar em minhas práticas o saber da Historia como disciplina do currículo e transmiti-la através da Língua de Sinais. Foi uma experiência muito radical, pois além de nunca ter feito isso, não tinha passado por nenhuma formação para aprender a fazer. Assim, construí minhas práticas bilíngues no dia a dia da escola, lançando mão dos meus conhecimentos e exercendo tudo isso através da língua de sinais.

Já o meu encontro com a Educação de Jovens e Adultos se dá em um contexto mais recente, em 2008, quando passei em um concurso no município de Cariacica e tive a 
oportunidade de escolher como posto de trabalho essa modalidade, foi desafiador e ainda o é. Contudo, enxergo nessa prática, possibilidades de contribuir para a formação dos meus alunos, através do exercício crítico da História, que é a parte que me compete, e que julgo muito pertinente para esta modalidade, pois anteriormente excluídos, por algum motivo, esses jovens e adultos retornam para as escolas e necessitam perceber através do diálogo com o conhecimento, possibilidades de projetar mudanças e repensar o presente e o futuro. Nessa prática, também procuro desenvolver as questões críticas, através das trocas, na esperança de produzir pequenas mudanças cotidianas no movimento da escola.

O meu encontro com a educação, os surdos e com a Educação de Jovens e Adultos foi a culminância de uma trajetória que tem, em cada especificidade enumerada, um foco inicial diferente, pois foram em momentos distintos da minha vida que me encontrei com essas questões.

Assim, pontuo de forma distinta os lugares que passei a ocupar, a partir do momento que me permiti estabelecer essas pontes entre ser professora, ser professora de EJA e ser bilíngue. $E$ foi esse ato de vivenciar essas experiências, esses atravessamentos, que me fizeram visualizar uma possibilidade de interlocução entre a surdez e a EJA, uma vez que, me relacionando com a comunidade surda, pude perceber o interesse dos surdos em retornar as escolas após a aprovação da Lei de LIBRAS 10.436/02 e o Decreto 5626/05, que permitiu o uso da Língua de Sinais de forma corrente nas escolas, após anos de proibição e de vigência do oralismo. $E$ como esses surdos haviam abandonado a escola anos atrás e encontravam-se na condição que o sistema denomina defasagem idade/série, o lugar ocupado por esses surdos na escola foi o ensino noturno, mais precisamente na EJA.

A partir desse movimento, que passa a ocorrer no final da década de 1990 e se estende até os dias atuais, percebo a preocupação dos surdos em concluir os seus estudos e se capacitarem para o mercado de trabalho. Surdos que anteriormente não tinham perspectiva de ascensão profissional, hoje procuram sua formação nas 
classes de EJA, em cursos profissionalizantes e no ensino superior.

Percebendo esse movimento, que tem caráter nacional, mas que ocorre com características específicas em nosso estado atentei-me à necessidade de pontuar a trajetória histórica dos movimentos surdos que culminaram com essas iniciativas atuais de busca pela qualificação profissional que os surdos tem se empenhado tanto.

Acredito que isso tem uma forte relação com as tendências atuais de inclusão e com a visibilidade que os movimentos surdos alcançaram, principalmente no final do século $X X$ em todo o mundo.

Desta forma, me coloco dentro desse movimento, não só como militante e professora de surdos e proponho uma revisão do percurso histórico que aponte essas tensões e as lutas dos surdos sobre o que eles julgam como direitos e que eu também faço essa leitura, tentando elucidar esse processo, para que dessa pesquisa brotem ferramentas que possam contribuir para a construção de uma educação de jovens e adultos surdos com a mesma dimensão que a EJA busca configurar, enquanto uma educação reparadora, equalizadora e qualificadora.

Sei que essas são as dimensões nas quais a EJA está fundamentada, contudo, percebo que a educação de surdos também pode ser fundamentada nesta perspectiva. Uma vez que, hoje, os movimentos surdos lutam por uma educação bilíngue com qualidade, buscando a afirmação dos seus direitos e sua formação para o mundo do trabalho.

A possibilidade desse diálogo surgiu quando de maneira curiosa indaguei meus alunos do Letras / LIBRAS como tinha sido a passagem deles pelo ensino médio. Eis aqui um grande susto: de uma turma de 30 alunos, 10 cursaram o Ensino Médio naturalmente, sem maiores problemas, 12 cursaram o Ensino Médio de forma conturbada com muitas reprovações, abandono e retorno e 08 deles só concluíram o 
Ensino Médio porque fizeram as provas do antigo Centro de Ensino Supletivo de Vitória (CESV), atual Centro Estadual de Educação de Jovens e Adultos - CEEJA.

Esses números me assustaram, e mais ainda os depoimentos dos alunos, sobre os percursos que enfrentaram para conseguir seus diplomas de Ensino Médio, pois caso contrário, não conseguiriam emprego ou ingressar na universidade. Assim, me senti motivada para a pesquisa. No intuito de refletir sobre o porque dessa situação atual dos jovens e adultos surdos e como a EJA e a Educação Técnico Profissional pode contribuir para que o passado de exclusão e negação de seus direitos e de sua língua, possa ser revisto e para que os mesmos tenham novas oportunidades.

A partir desta motivação, foi necessário pensar quais caminhos poderiam ser percorridos para conseguir problematizar essas questões com êxito. Meu primeiro passo foi pensar no contexto histórico no qual se deu a consolidação da Educação de Surdos enquanto uma área de conhecimento específico e sua trajetória. Afinal segundo Le Goff (2001), a história serve à ação (p.10), deste modo, não poderia ser outro o meu ponto de partida.

Resgatar esse passado, em primeiro lugar, é um exercício para mim, enquanto pesquisadora, uma vez que acreditava saber boa parte da história da educação de surdos. Ledo engano, eu mal sabia a metade dos fatos, assim, revirar estes escombros em busca dos elementos que me explicassem a situação dos alunos surdos jovens e adultos contemporâneos, foi primeiramente um esforço e consequentemente uma lição.

Mas, segundo Le Goff (2001) o historiador não pode ser sedentário, um burocrata da história, deve ser um andarilho fiel a seu dever de exploração e aventura (p.21), deste modo, realizar esta tarefa foi, sobretudo, seguir meus instintos de historiadora.

Assim, deste ponto inicial, foram brotando todos os passos subsequentes. É óbvio que a maioria do que trago como evidências históricas não foram vistas nem por 
mim, nem por aqueles que ouvi, narrando suas histórias ao longo do meu trabalho. Mas, tive o cuidado de ir ao encontro de fontes bibliográficas que puderam sanar minhas dúvidas, e nos fatos mais recentes, ai sim, foi possível enxergar a história pelas mãos e pelas vozes dos narradores e também, pelos movimentos surdos contemporâneos dos quais tenho feito parte e tido o privilégio de participar.

Sobre isto as contribuições de Bakhtin (2010a) e suas teorias que tratam a respeito da estética e da ética foram de fundamental importância para a observação desses fatos e seus processos de construção histórico-social. Afinal, ouvir contar, ler, compreender, tudo isso produz determinadas imagens em meu entendimento, que muitas vezes, não são àquelas enxergadas pelos sujeitos que vi e ouvi. Segundo Amorim (2007), este é um lugar de tensão, pois a imagem que eu posso fazer dos fatos, nem sempre é a imagem que àqueles que o viveram o fazem, por isso, 0 cuidado ao analisar os processos históricos torna-se crucial para que a ética e a estética possam ser observadas no caminhar da pesquisa. Ainda sobre este ponto Amorim ressalta que ao

[...], regular o trabalho da pesquisa e da atividade crítica: meu olhar sobre o outro não coincide nunca com o olhar que ele tem de si mesmo. Enquanto pesquisador, minha tarefa é tentar captar algo do modo como ele se vê, para depois assumir plenamente meu lugar exterior e dali configurar o que vejo do que ele vê. (2007, p.14)

O cuidado no transcorrer da pesquisa, para a preservação dos dados e o entendimento dos mesmos é primordial. Assim, observar os desdobramentos da história com os olhares de hoje é um anacronismo e, portanto, um erro. Assim, a busca de bibliografias que trataram sobre o processo educacional dos surdos de forma ética, foi uma preocupação, para que a militância não interferisse na coleta dos dados e para que a mesma também não pudesse ser deixada de lado. Muito pelo contrário, pois o compromisso com a ética, desde o início, permite-me ser militante ao longo do texto, pois em primeiro lugar, tenho o compromisso com a verdade. 
Sobre este posicionamento Amorim (2007), dialogando com o conceito de Exotopia em Bakhtin, proporciona uma reflexão muito relevante, pois como não estou na vida do outro e ele não está na minha, assim, mesmo para compreender o outro, eu vou até ele, mas retorno ao meu ponto de origem, pois é do meu lugar que constituo meus significados e assim o outro, da mesma forma. É neste movimento que me ponho a pensar. Afinal, se uma pessoa ocupasse o meu lugar e minhas visões, ela veria como eu vejo e eu, assim como ela vê, ai não seria necessário pensar. Assim, a Exotopia, é a possibilidade que eu tenho de resposta frente aos fatos que se põe a minha frente

\footnotetext{
Exotopia significa desdobramento de olhares a partir de um lugar exterior. Esse lugar exterior, permite segundo Bakhtin, que se veja do sujeito algo que ele próprio nunca pode ver; e, por isso, na origem do conceito de exotopia está a ideia de dom, de doação: é dando ao sujeito um outro sentido, uma outra configuração, que o pesquisador, assim como o artista, dá de seu lugar, isto é, dá aquilo que somente de sua exposição, e portanto com seus valores, é possível enxergar. (AMORIM, 2007, p.14)
}

Deste modo, este trabalho é primeiramente um esforço Exotópico, tanto em seus aspectos teóricos como empíricos, pois a preocupação constantemente presente nesta caminhada foi a de construção de pensamentos, reflexões sobre os processos históricos dos surdos e suas questões atuais. Deste modo, o lugar que eu ocupo, e as preocupações que eu deixo vir à tona, trazem a minha assinatura, assim, segundo Amorim (2007), torno-me responsável.

Em seu primeiro esforço, este trabalho traz as questões teóricas e metodológicas que inspiram as análises dos dados desta pesquisa. Na segunda parte, daremos foco aos dados sobre a História da Educação dos Surdos ao longo do tempo, explorando três realidades distintas que são o contexto da Europa, do Brasil e o do estado do Espírito Santo.

Em sua terceira parte, temos algumas análises sobre a legislação que garantem a este sujeito surdo jovem e adulto uma educação de qualidade com vistas a sua inclusão em todas as esferas sociais. Caminhando, em sua quarta parte, temos os 
resultados da pesquisa apresentados através das falas dos atores que participaram dos processos históricos investigados por este trabalho.

$\mathrm{Na}$ quinta parte, temos um diálogo com os surdos que ainda não chegaram ao ensino técnico-profissional e que almejam essa formação. Neste trecho, temos a responsabilidade em sinalizar que muitos surdos ainda encontram-se fora dos espaços de formação e que estes almejam formação profissional. Por fim, trazemos nossas considerações finais com o intuito de refletir sobre as diversas questões que este trabalho traz à tona. 


\section{CAPÍTULO 1 - CONTORNOS TEÓRICOS E METODOLÓGICOS}

Ao iniciarmos este capítulo apresentamos o relatório do desenvolvimento desta pesquisa, isso porque, a partir da discussão teórico-metodológica, torna-se possível a execução deste trabalho. Assim, nesta parte, traremos os principais conceitos abordados por nossos teóricos inspiradores, buscando a partir de uma reflexão inicial, apresentar os caminhos trilhados durante a pesquisa.

Para tanto, faremos uma discussão inicial sobre os conceitos bakhtianianos utilizados como norteadores na explicação acerca da construção teóricometodológica deste trabalho. Posteriormente, traremos ao longo texto, nossa escolha metodológica, baseada nas abordagens de Benjamin e Ricouer sobre a Narrativa como método.

Por último, a partir da enunciação do nosso problema, apresentamos um discussão sobre o passo a passo da pesquisa e algumas reflexões teóricas que nos auxiliam a compreender melhor o caminho trilhado durante a realização deste trabalho.

\section{A Exotopia como inspiração}

Por se tratar de um esforço Exotópico, este trabalho busca uma aproximação com o campo da pesquisa de duas formas: através dos discursos e das relações sociais. Numa tentativa de tentar ver, ou mesmo de ver imagens que os outros não veem de si próprios, e tentar a partir dai construir uma relação dialógica produtiva, onde esta imagem capturada, possa transmitir aspectos que realmente possam acrescentar construções de ideias e possíveis horizontes. E assim, nesta dialogia, produzir Exotopia.

Quando lançamos mão da Exotopia enquanto conceito norteador desta pesquisa, compreendemos que apenas no exercício de aproximação e afastamento, é possível compreender o universo no qual estão mergulhados os sujeitos com os quais são 
estabelecidos os diálogos que resultaram neste trabalho.

Exotopia é um conceito trabalhodo por Bakhtin em duas obras de sua autoria Problemas da Poética em Dostoiévski (2010) e Estética da Criação Verbal (2010). Nestes textos, o autor utiliza este conceito para mostrar como o autor desenvolve o seu personagem de forma independente, apresentando assim a sua visão sobre este, da mesma forma em que, às vezes, o autor se funde ao seu personagem dentro da obra, mas, para Bakhtin, em ambos, toda a produção é um excedente da visão que o autor tem sobre a obra, um exercício de aproximação e afastamento. Sobre este conceito Amorin (2007) nos diz que

\begin{abstract}
Enquanto pesquisador, minha tarefa é tentar captar algo do modo como ele se vê, para depois assumir plenamente meu lugar exterior e dali configurar o que vejo do que ele vê. Exotopia significa desdobramento de olhares a partir de um lugar exterior. Esse lugar exterior permite, segundo Bakhtin, que se veja do sujeito algo que ele próprio nunca pode ver; e, por isso, na origem do conceito de exotopia está a ideia de dom, de doação: é dando ao sujeito um outro sentido, uma outra configuração, que o pesquisador, assim como o artista, dá de seu lugar, isto é, dá aquilo que somente de sua posição, e portanto com seus valores é possível enxergar. (p.14)
\end{abstract}

Assim, por mais que nossa tentativa de tentar ver através do outro seja um esforço que se aproxime de sua visão, ela jamais será a visão do outro, pois somos primeiramente a nossa essência, vemos primeiramente nossas visões. Procurar estar no lugar do outro é apenas uma tentativa e dela geramos visões e consciência.

Esta aproximação possibilita uma atualização sobre o que está a frente, gera reflexões e concepções de ser e estar no mundo que são produzidas a partir desse exercício dialógico que produz exotopia.

Pensar desta forma não faz com que nós nos vejamos no outro como num espelho, ou mesmo que possamos conferir ao outro a nossa existência. Mas, é aproximar-se do que pretendemos ver, e talvez a possibilidade de nos enxergar no outro, poder gerar transformações inesperadas, ou talvez, uma consciência gerada por esta visão. 
Esta visão, por sua vez, gera uma imagem que passa a existir, contudo, ela não torna-se absoluta, pelo contrário, segundo Bakhtin (2010) esta imagem é inconclusa, dela partiremos para outras buscas, pois o fato de termos nos enxergado no outro, não significa que produzimos uma imagem acabada de nos mesmos, assim a Exotopia continua o seu exercício, ora aproximando-se ora afastando-se.

Segundo Bakhtin (2010a) "Não posso me alojar por inteiro no objeto; excedo qualquer objeto como seu sujeito ativo" (p.36). Assim, compreendemos que nossa visão produzida por esta relação é um excedente do outro.

Deste modo, este exercício proposto por Bakhtin é muito interessante para a pesquisa aqui apresentada, pois trazer ao longo deste texto depoimentos de "narradores" sugere uma aproximação a esses sujeitos, uma predisposição a ouvir atentamente suas histórias e consequentemente um envolvimento com as mesmas. Contudo, o alerta que Bakhtin sinaliza em sua obra nos capacita a entender que ao mesmo tempo em que apresentamos as histórias ao longo do texto, por vezes, é possível que eu esteja dentro delas, mas que elas não são um reflexo da minha história, mas um trabalho dialógico que produz visões e consciências para mim e possíveis leitores deste trabalho.

Uma outra importante contribuição de Bakhtin (2010a) para esta reflexão pode ser observada quando o autor relata que

No vivenciamento ativo desses atos são particularmente notórias sua eficácia e irreversibilidade. Neles realizo de modo notório e convincente o privilégio da minha posição fora do outro, e aqui a condensação axiológica dele se torna tangivelmente real. Porque só o outro podemos abraçar, envolver de todos os lados, apalpar todos os seus limites: a frágil finitude, o acabamento do outro, sua existência-aqui-e-agora são apreendidos por mim e parecem enformar-se com um abraço; nesse ato o ser exterior do outro começa uma vida nova, adquire algum sentido novo, nasce em novo plano da existência. (p.38)

Aqui Bakhtin sugere que a visão de quem está de fora pode ser privilegiada em 
relação ao outro. Ele compara a um abraço, um gesto que envolve por completo o outro, dando desta forma um sentido axiológico a esta relação. Lembrando que esta experiência é única, ela serve para calibrar o nosso olhar sobre o que está a nossa frente, mas não como uma repetição, pelo contrário, é uma experiência sempre nova, a exotopia não é algo acabado, mas uma relação que sempre se renova.

É como sair da caverna ${ }^{4}$, é uma vivência única, que por mais que a pessoa que saiu retorne para contar, os demais só conhecerão o que ele viu, se também, por iniciativa, esses também saíssem e vissem com seus próprios olhos o que existe fora do mundo que conhecem.

Bakhtin ainda sugere que

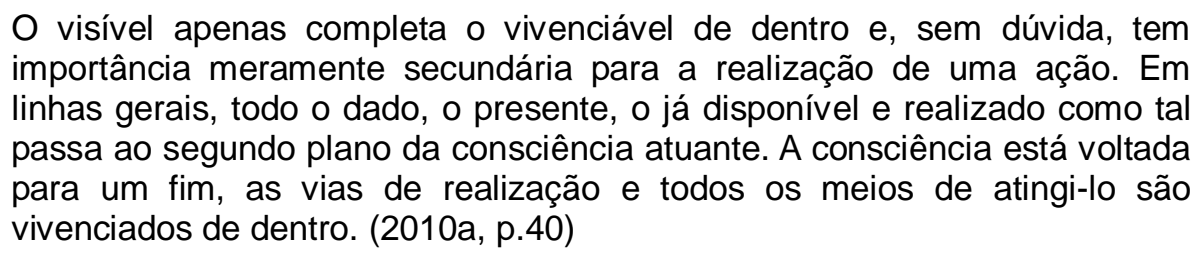

Assim compreendemos que a imagem produzida sugere muitas coisas, porém, a internalização dessas coisas vem mediante a vivência, por isso, apenas ouvir dizer não é o mesmo que experienciar um fato.

Pensando a partir dessas sugestões, podemos compreender que falar de um grupo sem aproximar-se dele é algo inviável. Assim, como apresentado na introdução deste trabalho, apontamos o ponto de partida de um lugar, onde encontramos os diversos grupos apresentados ao longo do texto.

É importante salientar este ponto, pois seria inútil um trabalho com esta visão bakhtiniana sem que houvesse uma relação constituída histórica e socialmente, pois são nessas relações que se dão a dialogia e a exotopia. Sobre isso Bakhtin nos diz que

4 Referência ao Mito grego da Caverna. 
Nesse sentido pode-se dizer que o homem tem uma necessidade estética absoluta do outro, do seu ativismo que vê, lembra-se, reúne e unifica, que é o único capaz de criar para ele uma personalidade externamente acabada; tal personalidade não existe se o outro não a cria; a memória estética é produtiva, cria pela primeira vez o homem exterior em um plano de existência. (2010a, p. 33)

Assim, esta aproximação se dá de forma que possa responder as inquietudes daquele que se aproxima, intencionando com essa atitude, captar o que se procura, afinal, nosso olhar não é neutro, nem desinteressado, pelo contrário, traz consigo as marcas de nossos percursos históricos. Desde as nossas percepções mais singelas, as palavras proferidas, todas trazem consigo a sua intencionalidade. Bakhtin, aponta que esse lugar de onde partimos, a nossa historia é a nossa assinatura. Assim, somos responsáveis pelo que iremos produzir a partir das nossas leituras, visões e dialogias. Contudo, para realizarmos o exercício da pesquisa e da escrita, devemos fazê-los com responsabilidade.

\section{Responsabilidade como dimensão ética e estética}

Amorin (2007) aponta que na pesquisa bakhtiniana é essencial este sentimento de pertencimento e responsabilidade, pois a ética torna-se um pressuposto essencial para que estes preceitos possam existir. Segundo a autora "para assumir o caráter de dimensão ética da criação será preciso fazer intervir a ideia de responsabilidade" (p.15).

Todos esses conceitos são baseados primeiramente no que Amorin denomina como conceitos bakhtianianos de "answerability" ou "responsiveness" presentes em suas teorias sobre o discurso. Nelas o autor aponta as questões referentes as relações éticas e estéticas. Segundo Amorin, Bakhtin aponta que a relação teoria e estética quando transformadas em ato, tornam-se éticas, ou seja, assumir o pensamento é assiná-lo, diz Amorin. Deste modo, são características primordiais para o pensamento ético.

5 Mantive a grafia adotada pela autora 
Assumir esta postura de compromisso com a pesquisa, a teoria e a estética, resulta em um trabalho ético, segundo Bakhtin, torna possível a existência de um pensamento não-indiferente, comprometido e com responsabilidade.

Todas essas pistas teóricas vão deixando um rastro a ser seguido, levando em conta o exercício da exotopia e o registro deste feito de modo ético e com responsabilidade, segundo as próprias palavras sinalizadas por Bakhtin. A adoção dessas posturas diante da pesquisa vai aponta para um caminho comprometido com o ser-verdadeiro, que segundo Amorin (2007), "é o dever do pensar" (p.17).

Amorin ainda ressalta que esses valores ocupam um campo na pesquisa bakhtiana que é comum em todos os momentos

[...] o ético e a questão do valor se dão sempre no lugar do acontecimento, do singular e irrepetível, o que equivale a dizer, no âmbito do concreto e do histórico. Para tornar o pensamento não-indiferente, é preciso responder por ele levando em conta o contexto em que nos encontramos. E o contexto será sempre uma arena onde diferentes valores se afrontam, engendrados nas diferentes posições sociais que ocupamos. O pensamento tornado ato é um pensamento valorado, um pensamento com entonação e que adquire, segundo a expressão de Bakhtin " a luz do valor" (2007, p.19)

Seguindo este caminho proposto por Amorin, compreendemos que ter Bakhtin como uma das inspirações teóricas deste trabalho nos ajuda a compreender a preocupação ética com a pesquisa.

Procurar conhecer o lugar do acontecimento e a história, compreender os sujeitos como seres históricos e conferir-lhes voz, serão características deste trabalho, durante o transcorrer da pesquisa. Assim, esse paradigma que enxerga o sujeito como um ser e não como um objeto de pesquisa nos dá a ideia que esta pessoa tem algo a nos contar. Deste modo, denominar os participantes da pesquisa como sujeitos, e não como objetos, é muito mais interessante, levando em conta a base teórica deste trabalho. 
Assim, Freitas (2007) evidencia que na abordagem bakhtiniana, que leva em conta o percurso histórico dos sujeitos, podemos realizar um exercício que consegue trazer esta discussão para o campo da relação dialógica.

\begin{abstract}
Considerando a pesquisa como uma relação entre sujeitos, portanto numa perspectiva dialógica, Bakhtin assume a interação como essencial no estudo dos fenômenos humanos. Salienta o valor da compreensão construída a partir dos textos signos criados pelo homem, portanto, assinalando o caráter interpretativo dos sentidos construídos. O sujeito é percebido em sua singularidade, mas situado em sua relação com o contexto histórico-social, portanto, na pesquisa, o que acontece não é um encontro de psiqués individuais, mas uma relação de textos com o contexto. (FREITAS, 2007, p.29)
\end{abstract}

Deste modo é possível compreender na visão de Bakhtin, que é na dimensão da dialogia que se dão as relações histórico-culturais que sugerem as pistas sobre os percursos dos sujeitos da pesquisa. Assim, faz-se necessário o conhecimento prévio de suas histórias, como alternativa para uma melhor compreensão de seus contextos sociais. Por isso, um levantamento sobre o passado desses sujeitos é tão importante para o esclarecimento de suas questões atuais.

Freitas (2007) ainda sinaliza que "a pesquisa nas ciências humanas a partir da perspectiva sócio-histórica implica compreendê-la como uma relação entre sujeitos possibilitada pela linguagem"(p. 29). Ou seja, nas relações sociais existentes entre os sujeitos da pesquisa é necessário a compreensão das expressões dos sujeitos, por ser o homem um ser que interage através das diferentes linguagens.

As interações humanas se dão principalmente através do diálogo. Neste sentido, o conceito bakhtiano de dialogia não pode ser ignorado, pois para Bakhtin, são nas relações dialéticas que se dão os movimentos. A dialogia seria uma dialética que explica as situações através do diálogo, as relações históricas e sociais se dão através desses exercícios dialógicos, onde pelo diálogo conseguimos alcançar diferentes formas de visão e compreensão dos que nos rodeia. Segundo Freitas (2007) 
humanos se realiza a partir de interrogações e trocas, portanto pelo diálogo. Diálogo compreendido não apenas como uma relação face a face, mas de forma mais ampla e implicando também uma relação do texto com o contexto. (p.30)

A partir desta reflexão, podemos apontar que o que rege as relações sócio-históricas é a dialética, ou seja, não podemos pensar em um outro ponto de partida de análise que não seja este. Assim, as observações feitas ao longo da pesquisa não podem ser apenas uma "tomada de notas" mas devem estar conectadas aos diálogos tecidos com os sujeitos da pesquisa de forma contextualizada.

A observação na pesquisa sócio-histórica é algo primordial, sendo realizada atrelada ao contexto dos sujeitos. Segundo Freitas ( 2007)

A observação, numa pesquisa de abordagem sócio histórica, se constitui pois em um encontro de muitas vozes: ao se observar um evento, deparase com diferentes discursos verbais, gestuais e expressivos. São discursos que refletem e refratam a realidade da qual fazem parte construindo uma verdadeira tessitura da vida social. (p.33)

Ou seja, abordar situações que envolvam a realidade das sujeitos, seus movimentos e suas lutas, para que assim, os dados discutidos possam realmente representar o percurso histórico-social dos envolvidos na pesquisa.

Outro ponto que não podemos deixar de observar é a posição histórico-cultural do autor, como dito anteriormente. Segundo Freitas, apesar do pesquisador trazer consigo as marcas da sua história, este deve ser comprometido eticamente e ter responsabilidade sobre o que produz.

São importantes estas considerações e a elas acrescento que a contextualização do pesquisador é também relevante. Este é um ser social que marca e é marcado pelo contexto no qual vive. Sua inserção no campo de investigação significa de fato sua penetração numa outra realidade, para dela fazer parte, levando para esta situação tudo aquilo que o constitui como um ser concreto em diálogo com o mundo em que vive. (FREITAS, 2007, p.37)

Assim compreendemos que em resumo, todas as circunstâncias apontadas por 
Bakhtin (2010a), Amorin (2007) e Freitas (2007) podem ser entendidas como um resumo da postura ética e estética do pesquisador frente a sua pesquisa.

\section{Notas bakhtinianas sobre a dialogia em pesquisa histórico-cultural}

Partindo do pressuposto do caráter exotópico desta pesquisa, não podemos deixar de evidenciar a dialogia como sendo um ponto de interseção entre o eu e o outro, pois a dialogia compreende este movimento, através das relações histórico-culturais.

A dialogia é uma atividade de interação, totalmente voltada para um movimento que envolve os sujeitos nela imbricados. Pensar na dialogia como um ponto de partida é compreender que nada no processo da pesquisa permanece isolado, mas o tempo todo relacionado.

Entender a dialogia como uma relação, não significa que ela será o tempo todo harmônica, pelo contrário, afinal são das tensões que nascem outras possibilidades. Talvez seja ai que podemos perceber a marca da alteridade como também sendo um componente desta relação.

Geraldi (2007) aponta a dialogia e a alteridade como sendo o alicerce do pensamento bakhtiniano.

\footnotetext{
Sem dúvida alguma, o pensamento bakhtiniano alicerça-se em dois pilares: a alteridade, pressupondo-se o Outro como existente e reconhecido pelo "eu" como Outro que não-eu e a dialogia, pela qual se qualifica a relação essencial entre o eu e o Outro. Evidentemente, assumir a relação dialógica como essencial na constituição dos seres humanos são significa imaginá-la sempre harmoniosa, consensual e desprovida de conflitos. Estes são os princípios gerais de toda a arquitetura do pensamento de Bakhtin e não serão aqui retomados, mas assumidos como axiomas. (p.42)
}

Tomando como reflexão a citação de Geraldi (2007) fica claro que as possíveis divergências e convergências existentes dentro de uma relação entre o "eu" e o "outro" torna-se algo completamente aceitável e que é nessa relação que a dialogia 
se dá.

Sendo assim, compreendemos que para uma pesquisa exotópica, que preza pela responsabilidade, ou seja, produzir um texto não-indiferente, comprometido com a ética e a estética em Bakhtin, também devemos considerar que a dialogia e a alteridade são princípios incontornáveis dos quais não devemos nos afastar, para assim, produzir um trabalho que realmente respeite a trajetória histórica e cultural dos sujeitos aqui evidenciados.

\section{Os caminhos percorridos ao longo da pesquisa}

Tomando como base os preceitos bakhtinianos que evidenciamos ao longo da primeira parte deste capítulo, aprofundaremos agora as questões referentes a quais os caminhos foram trilhados durante a pesquisa para que este trabalho fosse executado.

Primeiramente, escolhemos como ponto de partida contar a História da Educação dos Surdos. Essa escolha se deu devido a nossa opção teórico-metodológica em ter Bakhtin como inspiração, pois acabamos de problematizar o princípio bakhtiniano de dialogia, que compreende as relações histórico-culturais de forma dinâmica, e o tempo onde isso ocorre, é o tempo histórico.

Como ponta pé inicial, trazer a metodologia de trabalho executada nesta pesquisa permite esclarecimentos sobre como os dados aqui apresentados foram sendo coletados, isso desde a pesquisa bibliográfica inicialmente executada, com o intuito de responder ao primeiro passo de levantamento dos dados históricos e legais referentes à Educação de Surdos até o trabalho de escuta das narrativas dos sujeitos identificados, como referência das possíveis articulações da trajetória da Educação de Surdos, da Educação de Jovens e Adultos e da Educação Profissional Tecnológica existentes no espaço da Grande Vitória. 


\section{O Problema de Pesquisa}

Caminhando neste sentido, objetivamente, este estudo trabalhou no sentido de responder a pergunta: Quais os caminhos trilhados pelos alunos surdos no retorno à escola, especificamente, no Instituto Federal de Educação, Ciência e Tecnologia do Espírito Santo - Ifes, numa tentativa de trazer à tona, esse percurso, e quais os movimentos ocorreram dentro dessa escola?

Este problema de pesquisa nasce dentro dos movimentos surdos atuais em prol da educação. Assim, além de traçar este percurso histórico, também temos como intenção evidenciar essas lutas como um compromisso deste trabalho, a fim de preservar a memória dessas lutas com responsabilidade social e política.

\section{O Objetivo Geral}

Traçado o problema, foi necessário trazer à tona a trajetória do retorno dos surdos a escola através da Educação de Jovens e Adultos , quais os espaços de formação eles foram ocupando dentro dessa modalidade e quais os caminhos de formação para o mundo do trabalho eles tem trilhado. Fazemos deste ponto nosso objetivo principal.

\section{Os Objetivos Específicos}

Especificamente, realizamos ao longo da pesquisa um resgate histórico da Educação de Surdos e seus atravessamentos, vivenciados ao longo da história. Outro ponto que procuramos responder foi os aspectos relacionados as questões legais, na dimensão do direito à educação, além das legislações específicas pertinentes à Educação de Surdos, a EJA e a EPT

A partir dessa discussão, foi possível identificar alguns espaços nos quais o diálogo entre Educação de Surdos, EJA e a EPT ocorreram e ainda ocorrem em nosso estado. Deste modo, fazendo o trabalho de escuta dos narradores, foi possível 
identificar, nas falas dos profissionais envolvidos neste contexto e dos estudantes surdos jovens e adultos, alguns apontamentos de alternativas para 0 desenvolvimento deste trabalho nessa zona de contato entre essas três áreas de conhecimento específicos da educação.

\section{Ferramentas utilizadas como método}

Para realizar este trabalho, como dito anteriormente, lançamos mão de uma pesquisa bibliográfica e da escuta das Narrativas dos sujeitos envolvidos na Educação de Surdos, atrelada à EJA e a EPT. Nossa escolha metodológica emerge da necessidade de responder as questões postas como o problema e os objetivos desta pesquisa, isso porque compreendemos os sujeitos na perspectiva sóciohistórica e suas relações, assim nos propomos a escutar sobre o que eles tinham a nos a dizer, conhecer suas experiências e registrar suas narrativas

Para Benjamin (1994), o que diferencia a narração de uma história simplesmente contada, é a experiência. O narrador tem uma ligação forte com a história que ele narra, não só por ter "ouvido" contar, mas também porque esta é a sua história. Benjamin, aponta ainda que o narrador dá conselhos e sempre narra suas histórias com o intuito de transmitir sua experiência e aprendizado para àqueles de tomam conhecimento daquilo que é contado. A moral muitas vezes compõe o pano de fundo de suas histórias, com o intuito de transmitir sabedoria adquirida pela experiência dos mais antigos.

O ato do aconselhamento dá asas ao que é contado pois, este passa a ser transmitido como fonte de sabedoria, dando continuidade à narração. A tradição da narração está na oralidade ${ }^{6}$, o que deixa claro a diferença entre o ato de narrar, de transmitir experiências do ato de escrever. O narrador faz do ato de narrar um

6 Gostaria de tratar a oralidade como o ato de transmissão, pois os narradores que proponho "escutar", são surdos, o que propõe a transposição do sentido da fala, para uma língua sinalizada, do ouvir, para o ver. Assim, as narrativas dos surdos, são narrativas visuais, que contam sobre suas experiências de vida, suas histórias. 
momento único, no qual ele busca incorporar história e experiência, ele recupera a história pela memória, relacionando o ocorrido à sua própria experiência e assim, trazendo à tona aspectos específicos vivenciados por ele, ou contados à ele.

A narrativa, está ligada a história sobremaneira, pois é do seu exercício que hoje temos acesso a tantos dados perdidos na história resgatados através do conhecimento dos mais antigos.

A narrativa, que durante tanto tempo floresceu num meio de artesão - no campo, no mar e na cidade -, é ela própria, num certo sentido, uma forma artesanal de comunicação. Ela não está interessada em transmitir o "puro em si" da coisa narrada como uma informação ou um relatório. Ela mergulha a coisa na vida do narrador para em seguida retirá-la dele. Assim se imprime a narrativa e a marca do narrador, como a mão do oleiro na argila do vaso. (BENJAMIN, 1994, p.205)

E são esses conhecimentos, transmitidos por esses narradores que nos dão a chance de conhecer, muitas vezes, o que Hobsbawm (1998) denomina de a história de baixo para cima, numa referência às histórias dos movimentos populares, que hoje é possível registrar através do gravador as falas de senhoras e senhores que pertenceram a esses movimentos, fazendo uma relação com o que está impresso na memória das pessoas que pertenceram a esses movimentos e a história documentada, tentando evitar a criação de mitos, mas buscando alguma consistência nas falas dessas pessoas, buscando um outro enfoque, diferente daqueles destacados pelos que estão em cima.

Contudo, ao ler o texto de Hobsbawm, percebemos que este autor trata este método, que resgata na oralidade dados acerca da história, com muita suspeita, não que ele negue a autenticidade das memórias revividas por àqueles que contam sobre o que viveram, mas por medo da criação de mitos, afastando a história dos dados possíveis de se provar através de documentos.

É fato que para se narrar, é preciso ter uma vinculação com a história a ser contatada, pois só assim a atualização da narração feita pelo narrador através da 
memória, pode ter ligação ao fato narrado por ele. Benjamin (1994) destaca que o narrador descreve as circunstâncias em que foram informados os fatos que vão contar a seguir (p.205)

A memória é a mais épica de todas as faculdades (p.210). Ao trazer essa afirmação, Benjamin resgata o ato épico das narrativas gregas, que tanto contaram ao mundo acerca das crenças, modos de vida, guerras e política na Grécia Antiga. Essas narrativas ${ }^{7}$, como a llíada e a Odisséia de Homero, são tão ricas em descrição, trazem consigo de forma tão descritiva e peculiar a Grécia Homérica (séculos XII VIII a.C.) , que não só batizaram o período narrado por elas com o nome de Homero, seu autor, como são consideradas verdadeiras fontes documentais históricas do período em conjunto com os achados arqueológicos.

Por último, Benjamin afirma: Quem escuta uma história está em companhia do narrador; mesmo quem a lê partilha dessa companhia (p. 213). Ao destacar a figura do leitor, Benjamin deixa evidente que, a transmissão da narrativa e o registro em sua forma escrita não anulam a consistência da mesma, uma vez que a sua descrição, os detalhes e a memória atualizada pelo narrador, serão parte do texto escrito, e de uma outra forma, serão transmitidas a todos que por ventura a lerem. Um bom exemplo, são as obras de Homero que no passado foram transmitidas oralmente, hoje, encontram-se registradas no papel e cumprem seu compromisso de transmitir conhecimento e sabedoria a outras gerações.

Outro ponto suscitado por D'Angelo (2006) presente no pensamento de Benjamin é a questão da experiência. Segundo D'Angelo

O passado deixa de ser algo morto, sem vida, quando o historiador conecta o passado e presente e reabilita os acontecimentos soterrados pela história oficial. Para isso, é preciso construir uma nova memória e reconstituir a história dos vencidos. Assim, a memória ultrapassa o plano de vivência individual e torna possível a realização de uma verdadeira experiência capaz de retirar o indivíduo de seu isolamento. (p.34)

7 ZILBERMAN, 2011. 
Assim, a autora nos dá pistas de como devemos raciocinar acerca das experiências dos narradores e de como estas foram fundamentais para compreender os dados apresentados ao longo da pesquisa. Outro ponto importante é que não basta apenas escutar as narrativas mas que é necessário identificar as marcas dos sujeitos que estamos escutando, pois estes trazem consigo os detalhes do espaço-tempo de sua história e suas relações sociais.

D'Angelo (2006) ainda aponta que o tempo é um lugar onde podemos identificar várias pistas sobre as questões que ocorrem em nosso cotidiano, ou seja, podemos compreender o caráter dialético dos movimentos sócio-históricos ao longo do percurso. Segundo a autora

\begin{abstract}
Nesta perspectiva, o trabalho com a memória representa uma forma de resistência cultural e política. Em seu esforço de recuperação do passado oprimido, a memória deve se confrontar com acontecimentos traumáticos, e do ponto de vista da cultura e da educação nada mais traumático do que a barbárie que sustenta seus monumentos. Sobre eles o materialista histórico não pode refletir sem horror, pois se é, em parte, a apropriação privada do excedente da riqueza produzida coletivamente que possibilita a existência dos intelectuais, escritores, poetas e artistas, certamente todos os tesouros culturais "devem a sua existência não somente aos esforços dos grandes gênios que os criaram como à corvéia anônima dos seus contemporâneos. (D'ANGELO, 2006, p.36)
\end{abstract}

Assim, nesta perspectiva benjaminiana sobre o tempo e os acontecimentos, percebemos que ao discutir à educação, seja em qual modalidade for, nesta perspectiva, podemos encontrar importantes contribuições para a pesquisa em educação. D'Angelo destaca ainda que "a filosofia de Benjamin vem inspirando estudos e pesquisas que arrancam a educação de seus nichos institucionais e a colocam no mundo" (p.36).

Esta visão da autora, inspirada em Benjamnin, nos mostra o quão é importante sair do lugar de conforto, que é o lugar geográfico e buscar em um lugar dialético, pistas que possam nos levar a história vivida pelas pessoas e não apenas a inscrita nos documentos oficiais. Ou seja, perceber nas experiências expostas pelas narrativas 
dos sujeitos, fragmentos que possibilitem, a reconstrução das história sob diferentes perspectivas.

Pensar na narrativa como ferramenta de trabalho nos possibilita um contato com os sujeitos que viveram o espaço/tempo que nos propomos pesquisar. A riqueza deste encontro, presenciada no brilho dos olhos dos narradores ao contar suas experiências vividas, nos transmite aspectos sobre a história que o registro no papel não consegue evidenciar de forma tão clara, cheia de vida e história. D'Angelo (2006) considera este fluxo como sendo um campo de infinitas possibilidades. A autora afirma que "na dialética dos entrecruzamentos passado/presente, percebemos nossa finitude e os limites de nossa existência temporal, ao mesmo tempo em que nos damos conta das infinitas possibilidades que a vida nos apresenta “(p.41).

Assim, compreendemos que segundo D'Angelo a tarefa do materialista histórico crítico é revelar as lutas sociais que se dão nesses fragmentos da história trazidos pelos narradores. Deste modo, calibrar o olhar em direção aos movimentos sociais e a trajetória dos nossos sujeitos torna-se um trabalho fundamental.

\section{Benjamin, Ricouer e Bakhtin: inspirações para o trabalho de transcrição e tradução das narrativas.}

Nos propomos a utilizar esses três autores devido as questões que foram encontradas ao longo da pesquisa. Assim, lançamos mão de Benjamin como sendo o aporte teórico principal para a realização e análise das narrativas.

Ricouer, é utilizado como inspiração para compreender dois processos. Primeiro, dentro das narrativas, ele nos auxilia sobre as questões temporais e de geração, isso porque muitos dos narradores são sucessores de outros e também porque a morte aparece como um fator a ser considerado neste trabalho, e por isso, os vivos fizeram referência aos mortos e sobre isso Ricouer nos traz grande contribuição com 
a sua teoria de sequência geracional. E, em segundo lugar, porque ele também contribui teoricamente para a realização das traduções dos narradores surdos. $E$ Bakhtin, que já vem sendo utilizado desde os primeiros momentos deste texto, pois, este autor também nos favorece com importantes contribuições sobre os percursos históricos e sociais.

Assim, iniciamos com uma abordagem de Ricouer (1997) sobre a questão do tempo, pois por se tratar de uma pesquisa que busca trazer à tona, fatos já ocorridos, precisamos ter de forma clara, em quais perspectivas temporais este trabalho foi esculpido.

\begin{abstract}
À reinscrição do tempo vivido no tempo cósmico realizada pela história, responde, da parte da ficção, uma solução oposta das mesmas aporias da fenomenologia do tempo, a saber, as variações imaginativas que a ficção opera sobre os temas maiores dessa fenomenologia. Assim, a relação entre história e a ficção, quanto a suas respectivas potências de refiguração, permanecerá marcada com o signo da oposição. Todavia, a fenomenologia do tempo permanecerá como a comum medida sem a qual a relação entre ficção e história permaneceria absolutamente indecidível. (RICOEUR, 1997, p.174)
\end{abstract}

A preocupação exposta por Ricouer, talvez seja esclarecida pelo tão desenvolvido papel do narrador exposto anteriormente por Benjamin e posto sob suspeita por Hobsbawm. O fato é que, como a narrativa emerge do ato da fala, é imprescindível que as fronteiras de tempo e espaço, delimitadas por ela, estejam muito bem dispostas, para que o recorte atualizado pela memória obtenha crédito e não receba as suspeitas apontadas por Hobsbawm (1997).

Ricouer, aponta o tempo como a medida comum entre a ficção e a história, assim, compreendemos que ele aponta o tempo como o recorte onde se dá a narração e assim, a distinção entre a história e a ficção. Ele distingue o tempo em: tempo mortal $^{8}$, tempo histórico ${ }^{9}$ e tempo cósmico ${ }^{10}$. Nessa concepção, o tempo do calendário é atravessado por mitos e ritos, presentes na história. Assim, Ricouer

\footnotetext{
8 Tempo entre vida e morte

9 Recorte histórico, feito através de apontamentos na trajetória humana.

10 cronologia
} 
compreende que o tempo do calendário é um terceiro-tempo, presente entre o tempo psíquico e o tempo cósmico. Assim, ele problematiza os calendários apontando como diferentes calendários ${ }^{11}$ possuem um fato fundador, um eixo de referência, para antes e depois e por fim, unidades temporais.

Um outro ponto abordado por Ricouer (1997) é a sequência das gerações, onde os vivos ocupam o lugar dos mortos, dando sequência aos fatos, a transmissão da história, dando sentido ao terceiro-tempo, o tempo do calendário. Ele aponta que o uso do recurso de geração na filosofia da história é antigo (p.187).

\begin{abstract}
O enriquecimento que o conceito de geração traz ao de história efetiva é, portanto, mais considerável do que se poderia suspeitar. Com efeito a substituição das gerações subjaz., de uma ou de outra maneira, à continuidade histórica, com o ritmo da tradição e da inovação. Hume e Comte gostavam de imaginar o que seria uma sociedade em que uma geração ou substituísse outra de uma só vez, ao invés de fazê-lo pela contínua compensação da morte pela vida, ou não fosse nunca substituída, porque eterna. Essa dupla experiência de pensamento sempre serviu de guia, implícita ou explicitamente, para apreciar a importância do fenômeno da sequência de gerações. (RICOUER, p.188)
\end{abstract}

Assim, compreendemos que Ricouer aponta para a existência de uma tradição, que é pontuada pela existência da sequência geracional, na qual os narradores mais velhos, vão perpetuando seu conhecimento através da transmissão aos mais jovens, que um dia ocuparão os lugares dos mais velhos, dando sequência a tradição. Vale lembrar que a substituição, a sequência geracional, não é algo mecânico, onde simplesmente um é facilmente substituído por outro com a mesma medida. Não é assim que Ricouer analisa essa sequência. Ele traz à tona uma problematização feita por Dilthey, que aponta para a relação entre geração e tempo, na qual há uma relação entre o tempo exterior do calendário e o tempo interior da vida psíquica. Dilthey aponta que pessoas da mesma geração, expostas as mesmas influências, desenvolvem uma bagagem comum, isso seria possível entre pessoas contemporâneas. Na sequência geracional a relação é desencadeada através do cruzamento entre transmissão da bagagem e a abertura de novas possibilidades.

11 Tempo crônico 
(p.189)

Ricouer aponta duas conclusões possíveis sobre essa análise sobre o tempo e sobre a sequência das gerações. Sobre o tempo, ele aponta sobre como a morte está ligada à história, uma vez que ele relaciona o tempo mortal e o tempo público, separando os que se foram dos contemporâneos. E o pano de fundo destes tempos históricos é a sequência de gerações, nas quais os mortos dão lugar ao vivos, que se sucedem em gerações e mais gerações, absorvendo e transmitindo, o que seus antecessores deixaram e o que eles deixarão para os seus sucessores. A figura do ancestral, destacada como ícone e a figura dos sucessores como esperança.

É importante destacar a escolha desta concepção de Ricouer para este trabalho, uma vez que dois dos estudantes surdos que fizeram parte dessa história que nos propomos a contar e refletir, não se encontram mais entre nós. Um foi vitimado por uma bala perdida e o outro em um acidente automobilístico. Sendo assim, compreendemos que a morte acontece, mas ela não apaga a história.

Seguindo as ideias de Ricouer, compreendemos as questões expostas por ele acerca do tempo, não apenas como recorte, mas como: tempo fenômeno ${ }^{12}$ e tempo cosmológico $^{13}$. O tempo narrado é como uma ponte lançada sobre a brecha que a especulação não cessa de abrir entre o tempo fenomenológico e o tempo cosmológico. (p.421). Então, se a narrativa se dá dentro das brechas, precisamos estar atentos ao que o narrador faz questão de contar, levando em consideração o tempo cosmológico e relacionando estes ao fenômeno exposto pelo narrador.

O frágil rebento oriundo da união da história e da ficção é a atribuição a um indivíduo ou a uma comunidade de uma identidade específica que podemos chamar de identidade narrativa. O termo "identidade" é aqui tomado no sentido de uma categoria da prática. Dizer a identidade de um indivíduo ou de uma comunidade é responder à questão: Quem fez tal ação? Quem é o seu agente, o seu autor? (RICOUER, 1997, p. 424)

12 O tempo como fenômeno, trazendo o passado como memória, o presente como o que vejo e o futuro como possibilidade.

13 O tempo do cosmos. 
Observando quem é o narrador, de onde ele fala, a qual comunidade ele pertence, tudo isso, nos auxilia na coleta dos dados, no registro do que ouvimos contar. A narrativa nos responde a todas as questões que Ricouer aponta como dúvidas, e que ele mesmo responde utilizando-se de uma fala de Hanna Arendt, para quem a narrativa é contar a história de uma vida (p.424). Dentro do discurso do narrador, pudemos reconhecer quem ele é, de onde ele fala, e ele se auto-intitula pertencente a uma grupo, quando ele se nomeia, quando ele descreve.

\footnotetext{
A história narrada diz o quem da ação. A identidade do quem é apenas, portanto, uma identidade narrativa. Sem o auxílio da narração, o problema da identidade pessoal está, com efeito, fadado a uma antinomia sem solução. (p.424)

A noção de identidade narrativa mostra ainda a sua fecundidade no fato de que ela se aplica tanto à comunidade quanto ao indivíduos. Podemos falar da ipseidade de uma comunidade, como acabamos de falar da de um sujeito individual: indivíduo e comunidade constituem-se em sua identidade ao receberem tais narrativas, que tornam para um e para outro sua história efetiva. (p.425)
}

Deste modo, Ricouer nos aponta que a narrativa está estreitamente ligada a identidade do narrador, pois indivíduo e comunidade estão entrelaçados por um conjunto de tradições, dos quais o narrador está intimamente conectado.

Partindo das discussões apresentadas, utilizando a figura do narrador apresentada por Benjamin (1994) aliadas as discussões de Ricouer (1997) acerca do tempo, da sequência de gerações e de identidade, utilizamos a metodologia da narrativa como forma de alcançar os relatos da comunidade surda, sobre o retorno dos jovens e adultos surdos para a escola e de que forma isso se deu e se dá na atualidade, priorizando visibilizar quais são as principais questões apontadas por esse grupo. Além dos surdos, foram ouvidos profissionais da educação que conviveram com os surdos nos espaços/tempos pesquisados, tais como professores, pedagogos e intérpretes de língua de sinais.

A narrativa é um método baseado na tradição oral, cabe lembrar que os surdos 
apresentaram suas histórias de forma diferenciada, através de suas mãos, no seu universo visual-gestual, no espaço, onde são cravados os registros de suas memórias. E com olhos atentos as observações de suas "falas", foram feitos os registros desses narradores, através de filmagens, que posteriormente foram traduzidas. Já os narradores ouvintes, tiveram seus relatos gravados e posteriormente transcritos

Para trabalhar estes dois exercícios: tradução e transcrição, lançamos mão das inspirações teóricas de Benjamin (2012) em seu texto "A tarefa do Tradutor", Ricouer (2011) em "Sobre a Tradução" e Bakhtin (2006) em "Marxismo e Filosofia da Linguagem".

Os três autores trazem contribuições importantes para esta etapa da pesquisa, uma vez que ambos partem da dimensão da linguagem social e historicamente construídas para a exteriorização das experiências dos sujeitos da pesquisa, seja através de sua língua materna oral ou gestual.

Ricouer (2011) aponta sobre a importância do trabalho do tradutor e as recompensas que ele encontra no ato da tradução, isso devido ao estatuto incontornável da dialogicidade presente no ato de traduzir. $\mathrm{O}$ autor ainda contribui destacando que para realizar este trabalho é necessário uma compreensão cultural sobre o que está sendo dito, para assim, realizar a tradução. Entendemos aqui que para traduzir as narrativas dos sujeitos surdos não foi necessário apenas saber a língua em que os depoimentos foram gravadas, mas também estar a par da situação social dos indivíduos.

Assim, ao ver cada depoimento e compreender cada fala, de posse do computador foi possível registrar as histórias de cada surdo. Devemos também destacar que no caso dos depoimentos dos ouvintes, mesmo estes sendo em Língua Portuguesa, compreendemos que para realizar suas transcrições, também foi necessário conhecer o contexto sócio-histórico desses sujeitos. 
Todos os depoimentos foram gravados com câmera filmadora, no caso dos surdos, foi necessária a captação da imagem e no caso dos ouvintes, a captação do som.

Um outro ponto importante que devemos destacar neste processo está atrelado a escolha dos sujeitos participantes da pesquisa. Para tal escolhemos profissionais que se envolveram no processo de inclusão de três alunos surdos no Instituto Federal do Espírito Santo - Ifes, no Campi de Vitória e Serra. Os sujeitos ouvidos foram: três intérpretes, uma pedagoga, um coordenador de curso, três professores e um ex-aluno surdo ${ }^{14}$.

\section{Sujeitos da Pesquisa - Ifes}

\begin{tabular}{|l|l|}
\hline Professores & 3 \\
\hline Coordenador & 1 \\
\hline Pedagoga & 1 \\
\hline Intérpretes & 3 \\
\hline Ex-aluno & 1 \\
\hline Total & 9 \\
\hline
\end{tabular}

Fonte: própria

Além do Ifes, também desenvolvemos a conclusão de nossa pesquisa em um espaço denominado "EJA da Garoto ${ }^{15}$ ", no qual existem duas salas de ensino regular semestral na modalidade EJA. Cada turma tem 10 alunos surdos, sendo uma das séries finais do ensino fundamental e outra de ensino médio. Neste espaço, as aulas são ministradas por professores ouvintes e são simultaneamente traduzidas por intérpretes de LIBRAS.

Ali gravamos o depoimento de Augusto, responsável pela coordenação dos

14 Apesar de pesquisarmos a inclusão de 03 alunos surdos, só foi possível conversar com 01, pois os outros 02 faleceram ao longo da pesquisa.

15 Educação de Jovens e Adultos da Garoto -Proposta idealizada pela fábrica de chocolates Garoto que tem como parceiros: na parte pedagógica o SESI - Serviço Social da Indústria; na parte de tradução e interpretação a Caesar Libras e na estrutura física a Faculdade Estácio de Sá. 
intérpretes de LIBRAS e os depoimentos de 10 alunos surdos: quatro mulheres e seis homens, com faixa etária entre 22 anos até 45 anos. Na ocasião, foi feita também, uma roda de conversa com cada turma separadamente, com o tema: "Educação Profissional”, com o objetivo de conhecer quais são os planos dos alunos após o término desta fase de sua vida estudantil.

\section{Sujeitos da Pesquisa - EJA da Garoto}

\begin{tabular}{|l|l|}
\hline Alunos Homens & 6 \\
\hline Alunas Mulheres & 4 \\
\hline Intérprete & 1 \\
\hline Total & 11 \\
\hline
\end{tabular}

Fonte: própria

É importante ressaltar que cada narrador recebeu um pseudônimo, para preservar sua identidade verdadeira, afinal, como esta pesquisa possui um compromisso ético e estético, não poderíamos ter outra postura

Para registrar as narrativas, marcamos encontros com nossos narradores. Assim, esses encontros se deram em espaços combinados, sendo, dois residenciais, a sede de um grupo de estudos e em duas instituições de ensino.

Os espaços residenciais foi onde tivemos a oportunidade de gravar os depoimentos do intérprete Pablo, ex-funcionário do Ifes e do coordenador dos intérpretes da EJA da Garoto, o intérprete Augusto. Já na sede do Grupo de Estudos Surdos na Universidade Federal do Espírito Santo - GES/UFES, foram gravados os depoimentos da intérprete Cecília, ex-funcionária do Ifes, da pedagoga Anita, do professor e coordenador de curso Gabriel e também de José, ex-aluno do Ifes. Além dos professores Jorge e Lília.

Nos espaços de ensino, visitamos uma escola da rede municipal de Vila Velha, onde hoje trabalha a intérprete Simone, que foi a pioneira no trabalho de interpretação de 
Libras/Português no Ifes. E o outro espaço que fomos ao encontro dos nossos narradores foi na EJA da Garoto, onde foi possível conhecer as histórias de Maria, Laura, Mario, Isabel, Paulo, Alfredo, Valter, Celso, Antônio e Ana.

Além desses depoimentos, temos também as histórias de duas alunas do curso de Letras/LIBRAS da UFES que serviram como motivação inicial desta pesquisa, afinal, foi depois do conhecimento desses relatos que surgiu o interesse pela temática deste trabalho.

Os encontros com os narradores foram repletos de acontecimentos variados, pois, em alguns casos, além das histórias que envolviam os surdos, a EJA e a EPT, muitos deles falaram sobre outros acontecimentos que os atravessaram durante seus processos dentro daquele tempo/espaço que eles estavam relembrando no momento da filmagem.

No que se refere ao método de transcrição das narrativas, não foi utilizado programa de transcrição, mas sim o ver e o escutar cuidadoso de cada história.

O tempo de transcrição de cada narrativa variou entre duas horas e cinco horas. Foram coletadas cerca de 4 horas: 22 minutos: 16 segundos de depoimentos.

\section{Dialogando com a Teoria}

Algumas reflexões teóricas podem nos auxiliar para compreendermos as questões que surgiram ao longo deste trabalho. Penso que primeiramente devemos situar qual é o nosso ponto de partida, uma vez que estamos tratando de um grupo que reside em um "país sem fronteiras", pois no mesmo território geográfico, residem ouvintes, surdos, negros, brancos, índios, quilombolas, dentre tantos outros grupos, delimitados por fronteiras invisíveis aos olhos, porém, existentes pelas práticas de exclusão, determinismo e padrões sociais. Assim, as relações de forças seguem presentes em nossas relações sociais, causando reações de afirmações por parte 
de grupos distintos e políticas de ações afirmativas ao se declararem pertencentes a determinadas facções ou praticantes de determinadas religiões ou ideologias. Silva (2000) nos aponta que

\begin{abstract}
$\mathrm{Na}$ disputa pela identidade está envolvida uma disputa mais ampla por outros recursos simbólicos e materiais da sociedade. A afirmação da identidade e a enunciação da diferença traduzem o desejo dos diferentes grupos sociais, assimetricamente situados, de garantir o acesso privilegiado aos bens sociais. A identidade e a diferença estão, pois, em estreita conexão com relações de poder. O poder de definir a identidade e de marcar a diferença não pode ser separado das relações mais amplas de poder. A identidade e a diferença não são nunca inocentes. (p. 81)
\end{abstract}

Assim, acredito que o nosso ponto de partida são exatamente as relações de força entre identidade e na diferença, uma vez que segundo Silva, estas nunca são inocentes, e é sobre elas que gostaríamos de falar.

Quando um grupo se reconhece como pertencente a determinado território / cultura, compreendemos que este grupo fixou sua identidade em um parâmetro próprio deste determinado grupo. Assim, a identidade não nasce impressa nos genes, ela é desenvolvida no desenrolar das relações sociais. O indivíduo se forma a partir das relações com outras pessoas. Em Hall (2006) o sujeito sociológico possui o "eu" interior que é formado e modificado num diálogo contínuo com os mundos culturais exteriores. Assim, a Identidade costura o sujeito a estrutura(p.12).

Assim, compreendemos que a identidade é o que nos territorializa, faz com que nos enxerguemos como pertencentes a um lugar, mesmo que esse não seja um lugar território, mas um lugar onde nos encontramos com nossos pares, aqueles com os quais nos identificamos. Talvez por isso os surdos tem se movimentado tanto ao longo da história, por um lugar comum, onde seus pares pudessem estar presentes, fortalecendo, deste modo, suas relações linguísticas e culturais.

Deste modo, também não podemos deixar de ressaltar a presença de múltiplas identidades em um mesmo lugar, e essas podem ,ao mesmo tempo, ser instrumento de aproximação, mas também de distanciamento, uma vez que pela lógica ocidental, 
o que foge ao padrão é sinônimo de marginalizado. Abdala (2004) nos aponta que noções como centro e periferia continuam a ser ainda imprescindíveis ao pensamento crítico (p.13). O que nos leva a crer que por mais que se tenha afirmado o poder da identidade e o direito dos sujeitos em exercê-la, ainda mantém-se uma lógica de pensamento hegemônico. Contudo, Abdala nos diz, que esses grupos buscam exercer suas diferenças, eles se opõem contra essa lógica, e projetam suas expectativas no âmbito da nação, afinal, apesar de pertencerem a um grupo territorializado em determinada prática cultural, língua, ou credo, esse grupo primeiramente está situado geograficamente em um território-nação.

Então, de que forma esses grupos identitários distintos poderão exercer suas diferenças em conformidade de direitos que lhe garantam a igualdade social?

O célebre teórico Boaventura de Sousa Santos, em seu livro "A Gramática do Tempo", nos aponta uma frase muito instigante: se temos o direito a ser iguais sempre que a diferença nos inferioriza; temos direito a ser diferentes sempre que a igualdade nos caracteriza.(p.316). Boaventura aponta em sua afirmação uma condição incontornável sobre a relação entre igualdade e a diferença, pois se a diferença nos coloca em uma condição de desigualdade, temos condições de sermos iguais, e se igualdade nos coloca uma condição de generalização, temos direito a diferença.

Esta reflexão nos esclarece acerca de possíveis "armadilhas" discursivas , principalmente as que tentam maquiar a existência de uma igualdade, pois, pela reflexão do autor, percebemos uma metamorfose no conceito de diferença e de igualdade, de acordo com o meio ao qual somos expostos em situação de igualdade ou diferença.

Assim, se temos a igualdade como condição de cidadania, reconhecida pelos mecanismos legais de estrutura do poder, compreendemos que esta seria uma condição primeira para o sujeito ser-estar em nossa sociedade. Contudo, nas 
"armadilhas discursivas" estão tecidas as desigualdades, que nunca estiveram tão camufladas, pois historicamente falando, no passado da modernidade ocidental, a desigualdade era instituída, escancarada, na legalidade, gerando artifícios que garantiam a escravidão e a existência de classes sociais distintas, por exemplo. Entretanto, nos nossos dias vemos a existência de um discurso e de um Estado Providência, que legalmente, deveria atestar as condições de igualdade entre os sujeitos, contudo, isso não acontece. Sobre isso, Boaventura nos diz

\begin{abstract}
A desigualdade implica um sistema hierárquico de integração social. Quem está em baixo está dentro e a sua presença é indispensável. Ao contrário, a exclusão assenta num sistema igualmente hierárquico mas dominado pelo princípio da segregação: pertence-se pela forma como se é excluído. Quem está abaixo está fora (p.280)
\end{abstract}

Assim, compreendemos que as pessoas que encontram-se fora desses sistemas hierárquicos, estão excluídas dos processos sociais16. Então, retomamos a pergunta: como os grupos sociais poderão exercer suas diferenças de forma que alcancem a igualdade?

Seguindo as reflexões de Boaventura, percebemos que ele desenvolve algumas questões chaves que são muito importantes para o desenrolar de nosso trabalho, contudo, vamos nos ater a desigualdade, no sentido sócio econômico em Marx, como um dos autores que explora esta categoria.

Marx (2010), analisa as relações entre capital e trabalho, e dessa análise ele conclui que a condição do trabalhador como homem pauper17, uma vez que este tem como única fonte de subsistência a sua força de trabalho.

A capacidade de trabalho, despojada dos meios de trabalho e dos meios de subsistência é portanto, a pobreza absoluta como tal e o trabalhador, como sua simples personificação, possui realmente suas necessidades, enquanto

16 O conceito de exclusão social que Boaventura utiliza para falar sobre as desigualdades, está pautado nos movimentos das últimas décadas, que visa deslocar o conceito de desigualdade apenas do foco da pobreza e focá-lo também em outras realidades, como das diferenças.

17 Pobre 
possui a atividade para fazê-las apenas como desprovida de objetivo, como aptidão (possibilidade) encerrada em sua própria subjetividade. (p.53)

Assim, compreendemos que Marx nos aponta que as condições dos trabalhadores são àquelas reguladas pelo dinheiro e pelo valor de uso e de troca de sua força de trabalho. Desta forma, o grande contingente populacional que detém como única propriedade a sua força de trabalho, está alocado na porção social daqueles que são marginalizados por suas condições sócio-econômicas. Sobre isso Marx ainda nos diz

\begin{abstract}
Por outro lado, como a riqueza material, o mundo dos valores de uso consiste apenas de matéria natural que é modificada por meio do trabalho, portanto, apropriada somente por meio do trabalho, e a forma social dessa riqueza, o valor de troca, nada mais é do que uma forma social determinada do trabalho objetivado contido nos valores de uso, e como, porém, o valor de uso, o real uso da capacidade de trabalho, é o próprio trabalho, portanto, a atividade mediadora do valor de uso é criadora do valor de troca, então a capacidade de trabalho é tanto a possibilidade geral quanto a única fonte de riqueza material na forma social determinada que essa riqueza possui como valor de troca (p.53)
\end{abstract}

Então, na visão de Marx, as camadas populares trabalhadoras, estão condicionadas ao valor do seu trabalho e é dessa remuneração que o trabalhador alcança a sua sobrevivência. Por isso, Boaventura expõe que a hierarquização presente em nossa sociedade atual tem uma parte de sua gênese na desigualdade gerada pela relação entre capital e trabalho que Marx tanto salientou.

Assim, compreendemos porque a desigualdade sócio-econômica salienta a exclusão, pois as construções sociais pautadas nos princípios de diferenças de classes sociais pelo sistema do capital, gerou uma camada de excluídos, que são àqueles que não possuem nada, a não ser a sua força de trabalho, em detrimento de outras camadas que detém os meios de produção e acabam por subordinar as forças produtivas das camadas populares.

Deste modo então, como podemos localizar e reconhecer os seres humanos dotados de suas identidades e diferenças de modo que estas estejam postas e correlacionadas à sua existência de forma que estes sujeitos possam encontrar seu 
próprio modo de ser-estar no mundo, fora dos mecanismos de exclusão, sejam estes sócio-econômicos ou de grupo social?

Percebemos o crescimento da presença dos movimentos sociais dentro da educação, como forma de transformar o espaço da escola num lugar de discussão e convivência das diferenças, para que essas sejam entendidas não como algo que exclui, mas sim como uma outra afirmação do humano, bem diferente do ideal positivista que a modernidade idealizou, como o homem, branco, europeu e cristão.

Assim, esses movimentos passaram a dialogar com a escola, principalmente a partir do movimento de educação para todos, que ganha muita força a partir da década de 1990, quando a discussão da inclusão escolar passa, não só por grupos identitários, mas também outros grupos como os da Educação de Jovens e Adultos, da Educação Infantil o da Educação para o trabalho, dentre outros.

A presença desses grupos fortaleceu a discussão e propôs um outro caminho para a educação, bem diferente daquele que desconhece as diferenças e identidades dos sujeitos da escola. Um caminho que propõe alternativas para a inclusão de todos, em busca de qualidade de ensino e da permanência desses estudantes na escola. Giordani (2010), nos aponta a presença dos movimentos sociais nos espaços escolares como um forte contribuinte para a busca da garantia do direito à educação e pela igualdade de oportunidades.

Deste modo, o movimento dos trabalhadores por uma educação pública, gratuita e de qualidade para os seus filhos, o movimento dos professores por um reconhecimento de suas carreiras e pelo fim do apadrinhamento dentro das estruturas hierárquicas e burocráticas da educação, entram no movimento maior da década de 1980, no Brasil, pela redemocratização política do país e também pela democratização do ensino e inclusão de todos na escola, partindo do princípio do direito igualitário à educação. Esses movimentos em conjunto com a redemocratização do Brasil, culminaram em uma série de mudanças na educação 
em vários setores, na busca pela garantia pelo direito à educação, agora inscrito e garantido em uma Constituição Democrática.

Todos esses movimentos que problematizaram as situações de trabalhadores, pessoas socialmente excluídas por questões econômicas ou culturais, representam um grande movimento que acorreu a partir do final dos anos 1980. Assim, dentro deste contexto, do mesmo modo que as diversas categorias foram se movimentando, os surdos também buscaram sua inserção política e social ao longo dos anos.

Nos dias atuais, a comunidade surda tem estado presente nas discussões sobre 0 novo Plano Nacional da Educação - PNE, e tem buscado através de movimentações populares e sites na internet divulgar a causa das escolas bilíngues por todo o país. Essa presença constante nesses espaços tem possibilitado a conquista de muitas causas por parte da comunidade surda.

Além das questões sociais que excluem os surdos, devido a visão produzida, ao longo da história, sobre as pessoas com alguma deficiência física, sabemos que essa exclusão transcende o fato de não ouvir, mas vai de encontro a um preconceito linguístico em relação a língua de sinais.

Deste modo, antes de salientarmos as questões referentes a educação dos surdos, sua história, as questões legais e as narrativas desses sujeitos sobre os seus percursos, devemos entender que a questão linguística dos surdos é muito latente em todos esses espaços, devido a necessidade da comunicação apresentada pelos surdos ser de forma peculiar em relação aos ouvintes.

Para Yaguello (2006), que trabalha o pensamento de Bakhtin (2006) no prefácio da obra - Marxismo e Filosofia da Linguagem - , a comunicação está presente em todo ato enunciativo, daí a importância da língua, da palavra. Cada palavra traz consigo um universo de significados que foram a priori aprendidos e internalizados, e através 
das interações sociais, cada indivíduo soma os signos de cada enunciação aos demais que ele já possui internalizados, para produzir significado. Ele ainda afirma que as classes dominantes tem interesse em tornar o signo monovalente, contudo ele faz um contraponto de que só a dialética pode resolver a contradição aparente entre a unicidade da e a pluralidade da significação (p.16) Compreendemos que esse posicionamento do autor está posto devido as estratégias presentes nas massas discursivas que com o intuito de gerar regimes de verdade, impõe uma forma de compreensão única.

Contudo, Bakhtin (2006) defende que os significados dos signos vêm pelo movimento da internalização e da exteriorização dos signos, e para ele o signo e a situação social estão indissoluvelmente ligados. Assim, a palavra encontra-se carregada de ideologia, das questões cotidianas, e é nesse espaço que a língua se move. Então, se a língua é determinada pela ideologia, a consciência, portanto o pensamento, a "atividade mental", que são condicionados pela linguagem, são modelados pela ideologia (p.17).

Deste modo, a língua é o veiculo comunicativo que transporta e veicula a ideologia, é a expressão das lutas sociais e também é o lugar onde a expressão do pensamento se dá. Por isso, compreendemos porque a questão do surdo, é uma questão linguística, pois essa passa pela necessidade de expressão, de comunicação, enfim, do transporte através da língua, da cultura e da informação, da forma como eles almejam, a língua de sinais.

A dimensão que a Língua de Sinais possui dentro da comunidade surda, é a mesma que a Língua Portuguesa possui, para todos nós falantes desse idioma. A Língua Portuguesa é a materialização dos nossos sentidos, sentimentos, enunciações, posicionamentos políticos e de toda nossa forma de expressão, dentro de um conjunto maior que é a linguagem, tão bem reconhecida em nós brasileiros, de forma peculiar, pelo nosso jeito de ser, expresso de diversas formas, uma delas, na nossa língua. 
Assim, se seguirmos essa linha de reconhecimento de que a língua é o espaço onde todas essas ações acontecem, necessitamos ter a sensibilidade de que falantes de outras línguas, em nosso próprio país, também possuem esse sentimento, sejam eles índios, descendentes dos pomeranos, surdos, descendentes de japoneses, descendentes de alemães, dentre outros.

Sobre isso, Bakhtin (2006), nos aponta que o signo torna-se um signo, quando lhe é conferido um significado simbólico, assim, percebemos que quem confere este significado, quem promove o circular dessas informações, são os falantes das diversas línguas. Bakhtin explica que, para compreendermos um signo, precisamos ligá-lo a outros signos já existentes dentro da realidade na qual se está inserido, ou seja, dentro de uma língua, falada por um determinado conjunto de pessoas. Sobre esse aspecto ele ainda nos diz

\begin{abstract}
A consciência adquire forma e existência nos signos criados por um grupo organizado no curso de suas relações sociais. Os signos são o alimento da consciência individual, a matéria de seu desenvolvimento, e ela reflete sua lógica e suas leis. A lógica da consciência é a lógica da comunicação ideológica, da interação semiótica de um grupo social. Se privarmos a consciência de seu conteúdo semiótico e ideológico, não sobra nada. A imagem, a palavra, o gesto significante etc. constituem seu único abrigo. Fora desse material, há apenas o simples fisiológico, não esclarecido pela consciência, desprovido do sentido que os signos lhe conferem (p.34)
\end{abstract}

Tomando como a base a reflexão apontada na citação de Bakhtin, fica muito clara a questão da importância das relações sociais para o uso e significação da língua. Sobre esse aspecto, o autor ainda expõe sobre a importância da palavra e sua performance nos atos da fala, quando ele diz que

A palavra é o fenômeno ideológico por excelência. A realidade toda da palavra é absorvida por sua função de signo. A palavra não comporta nada que não esteja ligado a essa função, nada que não tenha sido gerado por ela. A palavra é o modo mais puro e sensível de relação social. (p.34)

Através das palavras o indivíduo materializa a sua consciência, produzindo um mundo de significados em conjunto com os seus pares. Como dito no início deste trabalho, através da citação do professor Fiori (2005), ninguém se conscientiza 
separadamente. Bakhtin (2006) apresenta a palavra como sendo o veículo de expressão da compreensão dos signos, para ele, o significado vem da interiorização do conhecimento e na relação social dos indivíduos, pois sem isso, a palavra seria meramente uma função biológica18. Assim, todo o signo ideológico, e portanto também o signo linguístico, vê-se marcado pelo horizonte social de uma época e de um grupo determinado (p.43)

As contribuições de Bakhtin para compreensão da dimensão da importância da língua enquanto uma articuladora das relações sociais entre indivíduos falantes de uma mesma língua são fundamentais, pois através da relação dialética proporcionada pelas palavras, aparecem as contestações, as questões de classe dentre outras. O que nos faz compreender como os regimes de verdade também são impostos pela língua, a partir de discursos reacionários, que criam verdades absolutas e através dos artifícios e performances linguísticas, conseguem torná-los reais $^{19}$.

Bakhtin ainda nos diz que todo o signo, inclusive o da individualidade é social (p.58), o que nos mostra o social respingando no individual e produzindo significado, e que tudo isso é marcado pela totalidade das condições existentes dentro de um dado meio social. A própria introspecção, na busca pela compreensão, também traz consigo as tendências ideológicas geradas primeiramente no contexto social ao qual o indivíduo pertence. Assim, a abstração dessas condições levaria ao enfraquecimento da capacidade mental, pois o signo não pode ser separado da situação social sem ver alterada sua natureza semiótica (p.62)

Desta forma, a interiorização do signo não pode ser separada do convívio social, pois é nessa relação que se dá a compreensão.

O pensamento de Bakhtin traz muitas respostas para a questão linguística dos

18 Emissão do som pelo aparelho fonador.

19 Ao longo do texto veremos como a construção discursiva do Oralismo foi capaz de manter a língua de sinais marginalizada por quase cem anos. 
surdos, pois se um indivíduo surdo considera-se falante da Língua de Sinais, através das teses defendidas por Bakhtin, este indivíduo deve em sua própria língua, em conjunto com seus pares apropriar-se dos conhecimentos que a sua língua traduz acerca do mundo e das relações dos seres humanos com ele. Pois, a interação dialética dos signos interior (significado) e o exterior (sinal) com o psiquismo e a ideologia, geram a compreensão e o entendimento da questão em reflexão.

Em toda enunciação, ocorre a relação dialética viva entre o psíquico e o ideológico, entre a vida interior e a exterior. A palavra (sinal) é o produto da interação viva das forças sociais (BAKHTIN, 2006, p.66). Cada palavra é um campo de discussão, é um ponto onde os valores sociais se apresentam. Sendo assim,

\begin{abstract}
Com efeito é indispensável que o locutor e o ouvinte pertençam a mesma comunidade linguística, a uma sociedade claramente organizada. E mais, é indispensável que estes dois indivíduos estejam integrados na unicidade da situação social imediata, quer dizer, que tenham uma relação de pessoa para pessoa sobre um terreno bem definido. É apenas sobre esse terreno preciso que a troca linguística se torna possível; um terreno de acordo ocasional não se presta a isso, mesmo que haja comunhão de espírito. Portanto, a unicidade do meio social e a do contexto social imediato são condições absolutamente indispensáveis. (BAKHTIN, 2006, p.70)
\end{abstract}

A presença do par linguístico é fundamental para a troca sugerida por Bakhtin, sem a afinação entre locutor e ouvinte, feita através da língua, e a existência de uma relação social real, torna-se impossível as trocas linguísticas e consequentemente a compreensão em sua plenitude.

Se pensarmos no que foi problematizado anteriormente, compreendemos que a questão da língua é o ponto de partida para pensarmos sobre a questão educacional dos surdos, pois se tomarmos os elementos expostos por Bakhtin (2006) e tudo o que ele nos diz sobre a língua, entendemos que é nela que se dão os processos de significação e aprendizado, através do seu exercício social.

Um outro conceito que pode contribuir para essa reflexão, é o conceito de dialogicidade. Zitkoski (2010) desenvolve esse conceito através das contribuições de 
Freire (2005), onde ele nos diz que

\begin{abstract}
O diálogo é a força que impulsiona o pensar crítico-problematizador em relação á condição humana no mundo. Através do diálogo, podemos dizer o mundo segundo nosso modo de ver. Além disso, o diálogo implica uma práxis social, que é o compromisso entre a palavra dita e nossa ação humanizadora. Essa possibilidade abre caminhos para repensar a vida em sociedade, discutir sobre o nosso ethos cultural, sobre nossa educação, a linguagem que praticamos e a possibilidade de agirmos de outro modo de ser, que transforme o mundo que nos cerca (p.117)
\end{abstract}

A dialogicidade proposta por Zitkoski em Freire, traz para nós a possibilidade de uma compreensão da realidade através do diálogo. E este por sua vez, se dá através da língua, assim, encontramos um ponto de convergência entre a dialogia proposta por Freire e a relação social através da língua de Bakhtin, ambas concordam e apontam para o mesmo foco - a consciência, com o intuito do entendimento do contexto e da História.

Sobre isso, ainda podemos destacar o que Freire (1983) nos diz sobre o ato comunicativo dialógico.

\footnotetext{
Em relação dialógica-comunicativa, os sujeitos interlocutores se expressam, como já vimos, através de um mesmo sistema de signos linguísticos.

É então indispensável ao ato comunicativo, para que este seja eficiente, o acordo entre os sujeitos, reciprocamente comunicantes. Isto é, a expressão verbal de um dos sujeitos tem que ser percebida dentro de um quadro significativo comum ao outro sujeito. (FREIRE, 1983, p.45)
}

Neste contexto, a dialogicidade aponta para a comunicação como sendo o canal onde a compreensão se dá, assim, falantes da mesma língua, pertencentes ao mesmo grupo, envolvidos por sentimentos identitários, exercem através do diálogo o exercício diário de entendimento, conscientização e transformação de suas realidades. Sem a comunicação e as trocas realizadas através do diálogo, torna-se inviável a produção da consciência, mais uma vez resgatando as palavras de Fiori (2005), não há produção de consciência de forma isolada, a conscientização vem pelas relações sociais. 
Assim, essas relações devem de forma natural, através de seus próprios movimentos, aguçar curiosidades, trocas e saberes, como resposta as relações dialógicas do cotidiano. A dialogicidade é fruto da criação humana. É uma das categorias possíveis para se pensar o mundo da vida, movido pela curiosidade (TESKE, 2005, p.143). Nessa troca, torna-se possível, como dito anteriormente, segundo Bakhtin (2006) que os indivíduos pertençam a mesma comunidade linguística e estejam, de forma imediata, integrados. E essa integração só é possível através da vivência.

Sobre essa curiosidade, Teske aponta que ela é fundamental para que outras questões, como a constante incompletude humana, que dá sentido a vida, na esperança de que diariamente, os horizontes possam se ampliar cada vez mais.

Se a integração dos indivíduos, segundo Bakhtin, deve ser algo imediato, Teske aponta que o conhecimento está para além das experiências imediatas. Acredito que ao expor tal problematização, a intenção de Teske é apresentar a importância das relações sociais de forma constante, uma vez que a minha relação imediata com determinado indivíduo, me dá respostas acerca de conhecimentos não imediatos, quando entro em contato com a experiência do outro e através da dialogicidade, posso ter acesso a conhecimentos não imediatos, que passo a conhecer através da troca que se dá através da interação dialógica social, tenho respostas as minhas curiosidades através do saber do outro. Sobre isso, Teske (2005) acredita que o multiculturalismo pode ser uma resposta interessante para a compreensão de realidades múltiplas e conhecimentos diversificados.

Assim, se estamos falando de sujeitos que falam a mesma língua e que através da relações dialógicas se constituem e produzem consciência, compreendemos que, os surdos são esses sujeitos, afinal, no uso de sua língua, em conjunto com seus pares, eles produzem o seu movimento, em prol da educação, dos direitos das pessoas surdas, dentre outras ações. 
Então, se pensamos em uma educação para surdos, devemos possibilitar a participação e a integração destes ao processo. Sobre essa questão, Teske (2005) nos diz
A ideia de educação multicultural (McLaren, 1997) está baseada no fortalecimento participativo dos alunos na comunidade onde interagem. Neste intercâmbio teórico,diferentes visões de mundo poderão ser contempladas na aquisição e construção do conhecimento. Outro objetivo seria envolver os alunos em análises críticas paradigmáticas na explicação dos conflitos, valores e ações de diferentes organizações sociais (p.145)

A partir desta reflexão, compreendemos que a participação dos sujeitos, através do exercício da dialogia, é fundamental para o estabelecimento de uma alternativa educacional que contemple as questões linguísticas e culturais dos surdos, ou de qualquer outro grupo cultural peculiar.

Então se para Freire o diálogo é o que propulsiona o pensar crítico, para Bakhtin é através do diálogo que a comunicação se dá. Assim entendemos que tanto a ideia de Freire como a de Bakhtin se encontram quando ambas colocam o diálogo como a ferramenta que conduz ao entendimento e o pensar crítico. Deste modo compreendemos que para a Educação de Surdos, de modo geral, os espaços escolares precisam propiciar aos educandos surdos a possibilidade de diálogo entre seus pares linguísticos.

Compreendemos que tanto a Dialogia em Bakhtin, exposta no início deste capítulo, quanto a Dialogicidade em Freire, são respostas interessantes para pensarmos a partir dessas relações, caminhos possíveis para a construção da articulação entre a Educação de Surdos, a EJA e a EPT. 


\section{CAPÍTULO 2 - TODO POVO TEM HISTÓRIA: A HISTÓRIA DOS SURDOS COMO PONTO DE PARTIDA}

Um bom ponto de partida para qualquer debate é uma retomada histórica. Pois, no exercício do pensar historicamente, vamos compreendendo o porque de determinados fatos, vamos capturando elementos que nos mostram boa parte do que vemos em nosso mundo hoje, fora as delícias do trabalho do historiador, que busca em fontes de cultura material e livros empoeirados o que nos constitui enquanto sujeitos histórico-sociais, através da História e da memória.

Assim, tomamos como ponto de partida a compreensão do sujeito surdo enquanto um sujeito histórico. Para essa tarefa, lançaremos mão, inicialmente, de quatro autores: Benvenuto (2006), Sácks (1998), Coelho (2007), Rocha (2008) e VieiraMachado (2012). Todos esses autores, abordaram de alguma forma em suas obras o passado dos surdos, desde tempos mais antigos até os dias atuais. Interessa-nos muito fazer este debate pois, a partir dos elementos históricos extraídos dessa discussão, serão atravessadas outras questões.

\section{A História da Educação de Surdos: o contexto europeu}

Para início, utilizamos o texto de Benvenuto (2006). A autora aponta em seu texto alguns elementos sobre a História dos Surdos de forma clara, é nesta obra que vamos nos esmerar e, a partir das questões postas por Benvenuto, vamos encaixando as exposições dos demais autores de forma sucinta, afinal, não é nosso intuito trazer à tona um trabalho historiográfico sobre os surdos, mas apenas trazer alguns pontos-chaves para futuras discussões que traremos neste texto.

Segundo Benvenuto, a História dos Surdos tem registros muito antigos. A autora aponta passagens da Bíblia, presentes no Velho Testamento, que abordam sobre a inutilidade do sujeito surdo no culto ativo a Deus. É muito comum na Bíblia a deficiência física de uma pessoa ser atrelada ao pecados dos pais. E o fato do filho ter determinada "falta" ser encarado como símbolo de maldição e de tornar público 
os erros da família. (p.231)

Sobre a Antiguidade Clássica, o texto faz menção à exclusão social que as crianças que nasciam disformes sofriam.

\begin{abstract}
$\mathrm{Na}$ Antiguidade Clássica, em Esparta, Atenas e Roma, as crianças que nasciam disformes eram "expostas". Essa prática consistia em levar as crianças a um lugar secreto fora da cidade para deixá-las morrer ou afogarse. As deformidades eram percebidas através de signos exteriores do corpo - pernas tortas, dedos a mais nas mãos, pés disformes. Marie Delacourt afirma: "Se elas eram expostas é porque davam medo: eram signo da cólera dos deuses e eram, também, a razão (dessa cólera). O que aconteceu com os surdos neste contexto? Não há provas, apesar de certas afirmações que asseguram que os surdos foram jogados dos precipícios de Atenas e Esparta. ( BENVENUTO, 2006, p.231)
\end{abstract}

Como dito por Benvenuto, não há registros dos surdos sofrerem esse destino, até mesmo porque a surdez, diferentemente das deficiências físicas, demora a ser detectada. Contudo, também não existem muitos registros que contam sobre a inclusão do surdos nos moldes sociais da Antiguidade Clássica.

$\mathrm{Na}$ Idade Média, os surdos não eram considerados monstros, porque seu traço é invisível, passavam despercebidos no meio da sociedade, podendo até desenvolver trabalhos manuais. Muitos foram adotados por entidades religiosas, pois muitas ordens faziam votos de silêncio e nelas, seus seguidores eram obrigados a comunicarem-se por signos. Nesses espaços a figura do surdo não era vista com estranhamento, inclusive são desses gestos, que mais tarde, surge a Língua de Sinais.

Nesse aspecto, vemos aqui um sujeito que deixa de ser descartado e passa a ser "incluído", de alguma forma, dentro da sociedade europeia medieval, contudo, ainda não é possível considerar que o surdo tinha um espaço reconhecido neste contexto.

Depois do século $\mathrm{VI}$, o Código Justiniano ${ }^{20}$ delimitou socialmente os direitos das

20 O Código Justiniano (530) distinguia cindo tipos de surdos: o que por natureza não escuta e nem fala não 
pessoas surdas, o que de certa forma, perturbou os membros da nobreza que tinham filhos surdos, pois se os mesmos não se enquadrassem nos perfis adequados de surdo que tinham os direitos civis contemplados no código, eles perderiam sua heranças hereditárias. Assim, surge a preocupação de promover a instrução para os surdos.

Seguindo o fluxo da História, é na Espanha, no início da Idade Moderna, que vemos os primeiros passos da educação de surdos de forma estruturada. Entretanto, isso foi motivado pelos interesses da nobreza em manter as propriedades das famílias.

\begin{abstract}
Os primeiros rastros da educação de surdos sob forma de preceptorado, apareceram na corte do rei da Espanha, com Pedro Poncé de Leon (15201584), monge beneditino, preceptor de dois filhos do marquês de Berlanga e sobrinhos do condestável de Castilla. O método de Ponce de Leon concentrava-se no aprendizado da escrita e da leitura, e para a compreensão das palavras, apoiava-se no desenho e na soletração através do alfabeto manual. $O$ direito espanhol previa que, se surdo sabia ler e escrever, podia fazer valer seus direitos. (BENVENUTO, 2006, p. 237)
\end{abstract}

Pedro Poncé de Leon cria o seu método, que apesar de fazer uso do alfabeto manual, tinha como objetivo o aprendizado da fala e da escrita. É considerado por muitos o pioneiro na educação de surdos, e de certo foi. Fato este que deve ser considerado, principalmente devido a sua origem monástica. A ordem da qual Pedro Poncé de Leon fazia parte, adotava o voto de silêncio e fazia uso da sinalização para a comunicação, fato este que ajuda Poncé de Leon na elaboração de seu método, que por sua vez, proporcionou aos surdos orientados por ele, a oportunidade de aprendizado dos sinais ${ }^{21}$, escrita e principalmente da fala. Contudo, essa era a realidade da elite abastada, aos demais surdos, restava uma vida de silêncio e miséria.

A situação das pessoas com surdez pré-linguística antes de 1750 era de fato uma calamidade: incapazes de desenvolver a fala, e portanto "mudos",

tem nenhum direito; o surdo por acidente, se sabia ler e escrever, dispunha de direitos; o surdo de nascença que fala, caso excepcional; o surdo por acidente que fala e o mudo que escuta, não tinham nenhuma privação de direitos. (BENVENUTO, 2006, p.237)

21 Lembrando que os sinais aqui mencionados são gestos e o alfabeto manual, é não a língua de sinais propriamente dita, mas sim a tradução das letras escritas para os sinais. 
incapazes de comunicar-se livremente até mesmo com seus pais e familiares, restritos a alguns sinais e gestos rudimentares, isolados, exceto nas grandes cidades, até mesmo da comunidade de pessoas com o mesmo problema, privados de alfabetização e instrução, de todo conhecimento do mundo, forçados a fazer os trabalhos mais desprezíveis, vivendo sozinhos, muitas vezes, à beira da miséria, considerados pela lei e pela sociedade como pouco mais do que imbecis - a sorte dos surdos era evidentemente medonha. (SÁCKS, 1998, p.27)

Segundo Coelho (2007), outros educadores se dedicaram, também, à educação dos surdos, procurando para tal, construir seus próprios métodos (Pablo Bonet, John Bulwer, John Wallis, George Dalgarno e Konrad Amman ${ }^{22}$ ) (p.40). O trabalho desses educadores estendeu-se durante toda a Idade Moderna.

Na França do século XVIII, surge um outro religioso o Abade De l'Epée, que para muitos estudiosos da área da surdez, foi o precursor do que hoje chamamos de bilinguismo para surdos ${ }^{23}$. Para Sácks, de l'Epée foi uma mente grandiosa (p.29), pois reconheceu a importância da língua de sinais no processo de aprendizagem dos educandos surdos. De l'Epée iniciou o seu trabalho assim como os outros professores de surdos, pretendendo alcançar o desenvolvimento da fala, contudo, ao longo do seu percurso, ele compreendeu que o seu método deveria ser reformulado, pois percebia que os surdos não conseguiam compreender completamente o ele Ihes ensinava e também, devido a sua fé Católica, em que cria que para alguém ser salvo, deveria compreender o seu erro, se confessar e rezar. Sem uma compreensão correta, os surdos jamais, em sua concepção, seriam salvos. Assim, De l'Epée encontra na língua de sinais nativa dos surdos pobres de Paris, a ferramenta que lhe faltava.

De l'Epée da início a um grande movimento educacional na França. Seu método que associava as palavras escritas a sinais e figuras, deu acesso aos surdos ao conhecimento. Ele mesclava os sinais com a gramática escrita francesa, assim, os alunos surdos podiam escrever o que Ihes era dito (SÁCKS, 1998, p. 31). Além

22 Todos os professores e pesquisadores sobre surdez aqui citados são oralistas, com exceção de John Bulwer.

23 No bilinguismo para surdos, o ensino dos conteúdos do currículo é feito através da língua de sinais e a língua do país é ensinada na modalidade escrita. 
disso, De l'Epée adotou também a presença do intérprete, que ia traduzindo tudo o que era dito em sinais, para que assim os alunos surdos pudessem anotar o que era dito e compreender o que Ihes era falado. A escola de De l'Epée foi fundada em 1755, recebia financiamento público e também era responsável pela formação de muitos professores surdos que o próprio abade treinava. Quando o abade morreu, em 1789, mais de 20 escolas para surdos haviam sido criadas na França.

O período histórico em que se dá a morte de De l'Epée, foi um momento conturbado da História da França, devido à Revolução Francesa, o abade Sicard (1742-1822) que sucedeu De l'Epée na direção da escola, foi perseguido e condenado a morte durante a revolução. Contudo, ele consegue fugir com o auxílio dos surdos, só conseguindo retornar após este conturbado período. (COELHO, 2007, p. 41). A partir desse momento, a escola de De l'Epée passa a ser chamada de Instituto Nacional dos Surdos-Mudos de Paris.

Tanto Sácks (1998) quanto Coelho (2007) apontam números generosos de escolas de surdos criadas na Europa a partir do movimento iniciado com De l'Epée. Coelho aponta a existência de mais de 150 escolas de surdos na Europa e 27 nos Estados Unidos.

O reflexo desse movimento foi a própria consolidação do modelo norte-americano, levado da França por Thomas Gallaudet, que contratou o professor surdo Laurent Clerc (pupilo de Massieu, professor que sucedeu o abade Sicard) e fundou nos Estados Unidos em 1817, o Asylum for the Deaf, em Hartford (Sácks, 1998, p.35). Neste asilo, Gallaudet e Clerc reproduziram o modelo de De l'Epée e o sucesso foi tão grande e imediato, que muitas outras escolas foram abertas. Calcula-se que em 1869 haviam 550 professores no mundo e que $41 \%$ desses professores nos Estados Unidos era, eles próprios, surdos (SÁCKS, 1998,p.37).

Sácks e Coelho ressaltam que o período que transitou entre 1770 até meados do século XIX, foi um grande momento na História dos Surdos, isso porque a 
multiplicação das escolas e de professores surdos foi algo que pôde proporcionar outros vôos a esses sujeitos. Coelho, em sua tese, expõe como eles estavam envolvidos a partir de então, em um universo cultural intenso, era possível perceber sua presença nos movimentos culturais, nos teatros e nos cafés de forma evidente, tanto na Europa, como na América.

Coelho ainda destaca a existência dos "banquetes surdos" ${ }^{24}$, que eram espaços onde a comunidade surda se reunia, era uma forma de encontrar os seus pares. Neles, os surdos da França, reuniam-se em torno da poesia e das artes, e também era possível, encontrar os surdos de outros espaços e outros tempos, como antigos companheiros de escola. Nesses banquetes haviam discursos e diversas manifestações da cultura surda.

Nota-se que o florescimento da vida acadêmica dos surdos no seculo XIX resultou num processo de expansão do surdo enquanto um ser que buscava participar do cenário europeu da época, eles não estavam escondidos, pelo contrário, segundo Coelho (2007), os surdos se faziam conhecer perante a sociedade civil. Nos banquetes, estavam presentes surdos de diversas regiões da Europa e até de outros continentes. Nesses espaços, os surdos ocupavam-se em discutir arte, política e também sobre as questões surdas, sobre a necessidade de expansão dos institutos de educação, pois muitos ainda encontravam-se sem formação escolar.

Uma outra preocupação que movia a comunidade surda neste período eram os debates sobre a metodologia de ensino para surdos que fervilhava na Europa no final do século XIX. Os surdos não assistiram os debates sobre a metodologia de ensino a ser adotada como referência para eles de forma passiva. Eles discutiram amplamente o tema, como muitos eram professores dentro dos institutos, ficava claro o posicionamento dos surdos em relação à língua de sinais.

24 Atualmente, esses banquetes podem ser vistos como as Associações de Surdos, espalhadas em todo o mundo, ou seja, os surdos viabilizando espaços para debater e socializar suas questões e sua cultura entre seus pares. 
O final do século XIX foi marcado por grandes discussões acerca da metodologia de ensino para surdos, principalmente devido às novas exigências decorrentes da relação entre Capital e trabalho derivadas da Revolução Industrial.

Em 1880, ocorreu um Congresso na Cidade de Milão onde professores de surdos, se reuniram a fim de discutir sobre os métodos utilizados nas escolas de surdos. Nesta ocasião, a maioria esmagadora era composta por ouvintes, o que fez com que a tendência metodológica do Oralismo vencesse nas votações.

Neste congresso destacou-se Gram Bell, inventor do telefone e casado com uma mulher surda, Gram Bell era um defensor árduo do oralismo e como havia acabado de ganhar prêmios devido a sua notável invenção, seu discurso ganhou mais peso ainda durante as votações. Cabe ainda destacar que neste congresso, os próprios professores surdos, foram proibidos de se manifestarem, sendo proibidos de votar, o método oral saiu vencedor nas votações e a língua de sinais ficou proibida.

Assim, após o Congresso de Milão de $1880^{25}$, os surdos foram proibidos de usar sua língua materna.

Os alunos surdos foram proibidos de usar sua própria língua "natural" e, dali por diante, forçados a aprender, o melhor que pudessem, a (para eles) "artificial" língua falada. E talvez isso condizente com o espírito da época, seu arrogante senso da ciência como poder, de comandar a natureza e nunca se dobrar a ela. (SACKS, 1998, p.40)

Com a aprovação dessa proibição, os surdos ficaram condicionados as práticas de treinamento oral e auditivo, pois este seria o método ideal a ser trabalhado nas escolas de surdos a partir de então

25 Congresso realizado na cidade de Milão - Itália, que reuniu educadores de surdos de todo o mundo, que instituiu a educação através dos métodos oralistas como sendo ideal para os sujeitos surdos. Cabe ressaltar que todos os educadores participantes do congresso eram ouvintes. "O método oral se imporá durante um século, depois do Congresso de triste memória que se realizou em Milão em 1880. Quanto mais se instalava a proibição da língua de sinais, a nova norma investia o corpo da criança surda, provocando a prática de novos dispositivos disciplinares." (BENVENUTO, 2006, p.240) 
Uma das consequências disso foi que a partir de então professores ouvintes, e não professores surdos, tiveram que ensinar os alunos surdos. A proporção de professores surdos, que em 1850 beirava os $50 \%$, diminuiu para $25 \%$ na virada do século e para $12 \%$ em 1960 ( SÁCKS, 1998, p.41)

Assim, todo o trabalho feito até então, as formações de professores surdos, a elaboração de métodos, tudo caiu em desuso. Os professores surdos ficaram desempregados, porque não podiam mais exercer suas funções. A vida acadêmica e cultural dos surdos começa a entrar em declínio a partir de então. Toda a cultura surda, que antes era vista como arte, passa a ser considerada marginal, uma vez que sua língua, forma clássica de expressão dos surdos, passa a ser desconsiderada.

Do mesmo modo que anterior ao Congresso de Milão a escolarização dos surdos se desenvolvia, na maioria dos países da Europa, ela sofre um declínio. Os surdos que iniciavam seus estudos eram separados dos surdos que estudaram na época em que a língua de sinais era permitida, o que gerava segregação dentro das escolas. 0 nível educacional dos surdos começa a entrar em decadência. Ficavam claras as diferenças existentes entre os surdos que haviam passado pelo processo de escolarização através da língua de sinais e os que passaram pelo método oral. Sobre essa observação Sácks aponta sua conclusão sobre o ocorrido nos Estados Unidos no mesmo período.

\footnotetext{
Nada disso teria importância se o oralismo funcionasse. Mas o efeito, infelizmente foi contrário ao desejado - pagou-se um preço intolerável pela aquisição da fala. Os alunos surdos da década de 1850 que haviam passado pelo Asilo Hartford ou por outras escolas desse tipo tinham um alto nível de alfabetização e instrução - plenamente equiparável ao de seus equivalentes ouvintes. Hoje em dia, ocorre o inverso. O oralismo e a supressão da língua de sinais acarretaram uma deteriorização marcante no aproveitamento educacional das crianças surdas e na instrução dos surdos em geral . $($ p.41)
}

26 Sácks ainda aponta neste mesmo contexto que muitos surdos são analfabetos funcionais e que o nível de leitura de surdos que concluíram o ensino médio, nos EUA na década de 1970, pode ser comparada ao nível de leitura dos primeiros anos do ensino fundamental das crianças ouvintes. Ele ainda cita as pesquisa de CONRAD (1979), autor inglês, que também aponta a mesma circunstância na Inglaterra. 
Com o passar dos anos, ficou muito clara a ineficiência dos treinamentos orais e auditivos no processo de alfabetização dos surdos, pois aprendendo por treinamento e repetição, os surdos demonstravam-se como perfeitos reprodutores do que thes era ensinado, contudo, em sua maioria, incapazes de uma leitura critica do mundo e de um exercício pleno da leitura escrita e do domínio da escrita. Sobre as práticas oralistas na educação de surdos e a ineficiência desse método, vigente em boa parte do século XX, Sácks diz:

Primeiro, eles são menos expostos ao aprendizado "incidental" que se dá fora da escola - por exemplo, àquele burburinho de conversas que constitui o pano de fundo da vida cotidiana, à televisão quando não legendada etc. Segundo, o conteúdo da educação dos surdos é pobre em comparação ao das crianças ouvintes: gasta-se tanto tempo ensinando as crianças surdas a falar - deve-se prever entre cinco e oito anos de ensino individual intensivo - que sobra pouco para transmitir informações, cultura, habilidades complexas ou qualquer outra coisa. (SÁCKS, p.41)

A partir dessa colocação podemos compreender o fracasso escolar a que surdos estiveram fadados durante anos, pois sem a comunicação necessária para a alfabetização e o aprendizado, os surdos ficavam bem aquém dos ouvintes nos diversos níveis escolares. Afinal, estamos falando de entendimento básico dos conteúdos, os quais, os surdos, não tem acesso, pelo impedimento da língua, que para eles era incompreensível, devido as situações históricas anteriormente expostas.

O Congresso de Milão foi um divisor de águas na História Educacional dos surdos, que marcou para sempre a situação subalterna em que os ouvintes enxergavam os surdos, pois não levaram em conta suas concepções quando escolheram adotar o "Oralismo Puro" como metodologia de ensino nas escolas de surdos. Infelizmente, os surdos que viveram naquela época, assistiram as escolas que antes thes pertencia, transformarem-se em um espaço onde sua língua não tinha mais lugar.

Coelho (2007) aponta que ao mesmo tempo em que as instituições para surdos passaram a proibir o uso da língua gestual, os surdos mantiveram sua língua, como forma de resistência, de forma escondida, pois era na escola que os surdos 
encontravam seus iguais e lá eles mantinham sua comunicação. Essa resistência fez com que a língua de sinais atravessasse todo o século $X X$ de forma marginalizada, mas enfim, ela sobreviveu.

O fato é que se por um lado o Congresso de Milão proíbe a língua gestual e impõe a metodologia oralista, por outro, ele não consegue extinguir a língua de sinais, nem a luta dos surdos, pois eles jamais desistiram de resgatar o que thes foi subtraído. Uma prova disso são as associações de surdos, que surgiram em várias partes do mundo. Muitas delas atualmente têm 50 anos de fundação, apesar da proibição da língua de sinais. Assim, compreendemos a importância do movimento social surdo para a manutenção da língua de sinais em todo o mundo.

\section{A História da educação de surdos no Brasil}

As informações históricas trazidas até então, apontam para um contexto Europeu e Norte-Americano, contudo, cabe aqui ressaltar que o Brasil também estava presente no desenrolar desta caminhada. Os relatos sobre a educação de surdos estão atrelados aos relatos da educação brasileira de forma geral. Entretanto, cabe sinalizar que a história da educação de surdos no Brasil está estreitamente relacionada a história da criação do Instituto Nacional de educação de Surdos (INES).

As primeiras instituições educacionais que surgiram no Brasil foram as escolas das primeiras letras. Essas escolas surgiram com o objetivo de ensinar a ler e escrever a camada branca da população. Com a independência do Brasil, as escolas de primeiras letras tornaram-se mais numerosas. Outra forma de se instruir as crianças, adolescentes e jovens, presente neste período, era o ensino individual, que era ministrado na casa do professor ou do aluno. Com o passar dos anos, as escolas foram se multiplicando, surgindo as escolas Normais ${ }^{27}$ e também as escolas que adotavam o método de ensino mútuo, em substituição ao método individual.

27 Escola de formação para o magistério 
É nesse período da história, no qual o Brasil ainda buscava uma estruturação para o seu método de ensino, nas escolas das primeiras letras, que a proposta da criação de uma escola para alunos surdos surgiu.

O professor francês e surdo Ernest Huet, apresenta ao imperador D.Pedro II, no ano de 1855, a proposta de criação de uma escola para surdos no Brasil ${ }^{28}$. Neste relatório, Ernest Huet apresenta duas possibilidades para a criação da escola. $\mathrm{Na}$ primeira proposta, ele sugere que a escola seja privada e que o governo conceda bolsas aos estudantes. Na segunda, ele sugere que a escola seja de total responsabilidade financeira por parte do Império. Para se matricular na instituição, o aluno deveria ter um perfil.

Para ser matriculado, o aluno deveria ter entre sete e dezesseis anos e apresentar um certificado de vacinação. O curso tinha duração de seis anos, com foco no ensino agrícola, em função das características socioeconômicas do brasil. Para as menins, eram as mesmas regras, além do compromisso de organizar uma sociedade beneficente composta por senhoras notáveis. (ROCHA, 2008, p.30)

Assim, Huet torna-se o responsável não só pelo início dos trabalhos educacionais oficiais com surdos no Brasil, mas também o precursor no uso da língua de sinais de forma oficial em nosso território. Sendo francês, ele introduz com o início de seus trabalhos, o uso da língua francesa de sinais em solo brasileiro ${ }^{29}$.

A escola começa os seus trabalhos no dia $1^{\circ}$ de janeiro de 1856 , no espaço da Escola M. De Vassinon, no Rio de Janeiro, a então sede do Império. Nos primeiros anos, a escola funcionaria neste espaço. Contudo, Ernest Huet não poupou esforços para conseguir junto ao imperador, as mesmas concessões que o Instituo de Cegos tinha. Em 1858, a escola muda-se para um outro prédio alugado, dando

28 Segundo ROCHA (2008), o documento da época, deixa transparecer que Ernest Huet, já tinha conhecimento da realidade brasileira em relação a educação de surdos, ou seja, que até aquela data, não existia uma iniciativa pública contundente a esse respeito.

29 Por este motivo a Língua Brasileira de Sinais pode ser considerada derivada da Língua Francesa de Sinais, pois ela foi constituída a partir desta, associada aos sinais que posteriormente foram sendo criados no Brasil e os regionalismos aqui desenvolvidos. 
inicio a sua constituição enquanto Imperial Instituto dos Surdos-Mudos.

Sobre este mesmo período Rocha (2008) traz um relato interessante do diário de D.Pedro II, no qual ele conta sobre sua visita a uma escola de surdos-mudos em sua viagem aos Estados Unidos. Neste relato Pedro II mostra-se encantado com o que presenciou. A escola que ele visitou foi a instituição fundada por Thomas Hopkins Gallaudet, em parceria com o surdos francês Laurent Clérc, em 1815. (.32)

Ernest Huet permanece na direção do instituto ate o ano de 1861, quando ele deixa o cargo. Em 1862 chega ao Brasil o novo professor contratado para chefiar os trabalhos no instituto o Dr. Manoel de Magalhães Couto. Sob sua direção o instituto teve seu quadro de funcionários regularizado e seu sistema de ensino foi institucionalizado, para o ensino foram selecionadas as disciplinas: Leitura e Escrita, Doutrina Cristã, Aritmética, Geografia com ênfase no Brasil, Geometria Elementar, Desenho Linear, Elementos de História, Português, Francês e Contabilidade.

Um outro trabalho que o instituto tinha como responsabilidade era o de formação profissional para os surdos, quando concluíssem seus estudos, tivessem uma profissão. Obviamente, a proposta contemplava apenas a formação para trabalhos manuais, não houve nenhuma proposta que sugerisse um outro tipo de formação.

Depois que essas medidas foram tomadas, o instituto só foi ser indagado sobre o trabalho que estava sendo realizado em 1868. Foi quando Dr. Tobias Rabello Leite, em nome da Seção da Secretaria do Estado foi tomar conhecimento do que realmente estava acontecendo. E a conclusão de sua averiguação foi que o instituto estava servindo de asilo para os surdos e nada mais.

Após suas averiguações Dr. Tobias foi nomeado diretor interino, essa situação permanece té 1872 , quando ele passa a ser o diretor efetivo, permanecendo no cargo ate sua morte em 1896. 
Nos primeiros momentos de sua administração, Dr. Tobias teve grandes dificuldades, pois não havia nenhum documento ou metodologia descrita na qual ele poderia se amparar. Assim, aos poucos, ele foi constituindo suas diretrizes. Sobre este desempenho Rocha (2008) aponta as primeiras medidas do diretor Dr. Tobias.

\begin{abstract}
O novo diretor implementou uma série de iniciativas com o objetivo de melhorar a rotina da Instituição. Uma das metas principais do Dr. Tobias era a de oferecer ensino profissionalizante. Ele acreditava que o aluno surdo, após a conclusão do curso, deveria dominar um ofício para garantir sua subsistência. Além disso, defendia que, pelas características do Brasil, o foco deveria ser $\mathrm{n}$ ensino agrícola. Para tanto, mandou preparar num terreno anexo ao jardim do Instituto uma pequena horticultura, onde os alunos pudessem aprender atividades agrícolas, servindo de base para uma futura atividade econômica. Em sua opinião, o objetivo dos Institutos de Surdos não era o de formar homens de letras, mas ensiná-los uma linguagem que os habilitassem a manter relações sociais, tirando-os do isolamento provocado pela surdez. (ROCHA, 2008, p.40)
\end{abstract}

A linguagem defendida por dr. Tobias, que Rocha faz menção em seu texto, era a linguagem escrita e a vocal artificial, para aqueles que fossem aptos. Contudo, tornou-se uma prática dentro do Instituto que os alunos que iam se formando passavam a ensinar os novos alunos, imitando o modelo do Instituto de Surdos da França. Neste contexto, apesar da linguagem priorizada ser a escrita e a falada, a língua de sinais também era corrente, pois os surdos a utilizavam entre si no processo de ensino dos novos alunos.

Outra iniciativa foram as traduções dos materiais utilizados no Instituto de Paris para a Língua Portuguesa, para que estes pudessem ser distribuídos nas outras províncias, uma vez que o Instituto, apesar de receber surdos de fora do Rio de Janeiro, era incapaz de atender a todos. Inclusive Dr. Tobias sinaliza a necessidade da abertura de outros Institutos no Brasil, contudo, as províncias mostraram-se desinteressadas em executar esta iniciativa.

O Instituto foi seguindo uma linha de trabalho bem próxima da executada na França, utilizando professores surdos, traduzindo os materiais franceses e fazendo uso da língua de sinais e também do ensino da linguagem escrita e da vocal artificial. 
Como abordado na parte inicial deste histórico, em 1880, o Congresso de Milão determina a adoção do método oral puro como metodologia de ensino para surdos. No Brasil, os efeitos da discussão levantada em Milão serão sentidos três anos mais tarde, em 1883, quando Dr. Tobias continuava a defender o ensino profissional e o uso da linguagem escrita e da vocal artificial (aos surdos que tivessem aptidão) e o Dr. Menezes Vieira que defendia o Oralismo Puro. O Dr. Menezes Vieira defendia o seu discurso baseado na tendência europeia após uma viagem realizada por ele, onde foi possível constatar que a maioria dos surdos na Europa estavam sendo oralizados. Deste modo incia-se a discussão sobre o método a ser adotado no Brasil.

Com o advento da República, o Dr. Tobias manteve-se no cargo, contudo, o que antes era o Instituto Imperial dos Surdos-Mudos passa a ser o Instituto Nacional dos Surdos-Mudos (o atual INES ${ }^{30}$ ).

Com a morte de Dr. Tobias 1896 o modelo adotado no Instituto passa a priorizar o ensino da fala articulada. Alguns gestores que posteriormente ocuparam a vaga de diretor do Instituto, como o Dr. Paulo de Carvalho, defenderam o ensino da fala para os que fossem aptos e para aqueles que não fossem, que fosse mantido o método antigo. Entretanto, em 1911, o método oral passa a ser o oficial no Brasil.

A partir de então, o Oralismo Puro passa a ser a prática dos professores com os alunos surdos no Instituto e também nas demais partes do Brasil. Em 1925, assim como O Benjamin Constant o INES passa a ser uma escola profissionalizante. Entretanto, o Instituto não consegue promover de forma adequada a formação dos alunos, devido a precariedade de suas instalações e falta de investimentos. Essa situação se estendeu até o período Vargas. Percebemos aqui que, por mais que houvesse uma intenção em incluir os surdos no mundo trabalho, esta tentativa sempre estava atrelada a beneficência ou por uma ação isolada, não como politica

30 Instituto Nacional de Educação de Surdos - INES 
pública ou porque o futuro dos surdos realmente importasse.

Na Era Vargas o Instituto sofre algumas alterações e passa a ser dirigido pelo Dr. Armando Lacerda, o qual também foca a sua gestão nas práticas oralistas e nos treinamentos auditivos. Na mesma época foi garantida a presença das meninas no espaço do Instituto, contudo, em regime de externato. Elas poderiam cursar as aulas de oralidade e os curso de bordado e costura. Como eram muitos os surdos que não conseguiam desenvolver aptidão para a fala, o Dr. Armando cria um método de atendimento que focava o ensino da escrita para aqueles que não falavam.

Rocha (2008) salienta ainda que durante a década de 1930, ocorreram diversas atividades dentro do Instituto. Muitas reportagens foram feitas na época para divulgar o trabalho que ali era feito, inclusive, foram publicadas várias fotos dos alunos, uma em especial, na qual estão dois alunos conversando em sinais, dado interessante, uma vez que a língua de sinais estava "proibida" dentro das instituições escolares. Outras informações publicadas pelos jornais e revistas da época são a respeito das oficinas profissionalizantes e sobre a ala feminina.

Dr. Armando permaneceu na direção do Instituto durante toda a Era Vargas, e uma reclamação muito comum apontada por ele, era a respeito do espaço físico limitado, uma vez que uma ala do Instituto passou a ser utilizada como repartição pública e uma outra queixa era devido a falta de recursos e empenho do governo no ensino das pessoas com surdez.

Com o fim da Era Vargas, Dr. Armando foi exonerado de seu cargo, quem assume a direção do Instituto foi Antônio Carlos de Mello Barreto. Segundo Rocha (2008), Antônio Carlos tinha o perfil disciplinador, o que causou muita revolta em alguns alunos, culminando com uma rebelião por parte dos surdos no ano de 1950. Muitas especulações foram feitas em torno deste fato, considerando ser uma possível ação comunista, uma vez que Dr. Armando Lacerda era ligado ao Partido Comunista que 
encontrava-se na ilegalidade nesta época. Contudo, foram apenas suspeitas.

Durante o governo de JK, a direção do Instituto ficou sob responsabilidade de dona Ana Rímoli, esta foi responsável por vários cursos de Fonética e Didática Especial para a formação de professores de surdos. Contratou a professora argentina Ângela de Brienza, árdua defensora do oralismo. Outra iniciativa deste período foi a oferta de formação, referente ao ensino médio atual aos alunos surdos. Outra mudança importante neste período foi a mudança do nome do Instituto, ocorrida no ano de 1957, onde o Denominado Instituto Nacional dos Surdos-Mudos passou a se chamar Instituto Nacional de Educação de Surdos - INES.

Nesta mesma década foi comemorado os 100 anos do Instituto. Nesta ocasião o Instituto recebeu a visita célebre de Hellen Keller, surda e cega, famosa por sua trajetória acadêmica de sucesso. Neste evento Rocha (2008) destaca a presença da professora Álpia Couto, importante personagem da História da Educação dos surdos no Espírito Santo.

Rocha (2008) afirma que no final da década de 1950, o Instituto começou a abandonar a influência francesa do Instituto Nacional dos Jovens Surdos de Paris e começou a se voltar pra o modelo norte-americano criado por Gallaudet e Clérc.

Durante a década de 1960 vários diretores alternaram-se na direção, dando continuidade ao trabalho de Ana Rímoli, ofertando o ensino profissional, mas também privilegiando a continuidade dos estudos nos primeiro e segundo graus. Contudo, na década de 1970, foram iniciados os atendimentos com as crianças pequenas, a professora Ivete Vasconcelos foi a primeira professora a estimular bebês surdos no Brasil. Ela também iniciou a divulgação do método da Comunicação Total $^{31}$ no Brasil.

31 Método de ensino para pessoas surdas no qual são utilizados gestos no ensino da fala e também a língua de sinais. Contudo, seu objetivo ainda é a oralização do sujeito surdo. 
Nesta época ainda era muito difícil para um surdo tornar-se professor, pois o objetivo do trabalho era o desenvolvimento da fala, e sendo assim, não conseguiriam dar conta das etapas que este trabalho exigia. Muitos profissionais defendiam a formação e a contratação de professores surdos neste período, contudo, isso ainda foi adiado.

O primeiro curso oferecido pelo Ministério da Educação - MEC de Especialização na Área de Deficiência Auditiva, foi no ano de 1981. Em 1984, o INES realizou um concurso para efetivação de pessoal, muitas das pessoas que passaram, foram alunos desta especialização promovida pelo MEC.

\section{A História da Educação de Surdos no Espírito Santo}

Como os demais estados, o Espírito Santo, precisou aguardar o envio de professores formados no INES, pois esta era a instituição responsável por formar professores normalista para atuar na educação de surdos, utilizando o método oral. Em 1956, o INES firmou um convênio com Minas Gerais, o Distrito Federal, Santa Catarina, São Paulo e o Espírito Santo. Esses convênios possibilitaram a expansão do atendimento aos deficientes da audição por todo o território nacional (COUTOLENZI, p.36). A portaria do INES que deu origem a esse convênio foi a ํo 196 de 21/05/1956.

Assim, a partir desse convênio, chegaram ao Espírito Santo três professoras oralistas: Gelcy Couto Matos, Leda Gonçalves e Alpia Couto-Lenzi. Essas professoras foram responsáveis pelo início do trabalho da área no Espírito Santo. Todas foram formadas no curso de formação de professores do INES.

Assim, foram criadas, por intermédio do governo do estado, classes especiais no Centro de Saúde, que mais tarde, devido a grande demanda, foram transferidas para a escola Ângela de Brienza. Nas classes especiais, as crianças eram educadas no método oral, realizavam atividades culturais e religiosas. 
Em 1970, a agora escola de surdos, passa a funcionar em um outro prédio, alugado pela secretaria de Educação, e a ser designada Instituto Oral do Espírito Santo. Em 1974, é criada oficialmente a "Escola Especial de Educação Oral e Auditiva".

A partir da década de 1970, o Espírito Santo passa a ter o seu próprio curso de formação de professores especializados de surdos, o que possibilitou, após a formatura da primeira turma de professores, a ampliação do atendimento aos alunos surdos em todo o estado.

Em 1977, a "Escola Especial de Educação Oral e Auditiva" passa a ser chamada de "Escola Oral e Auditiva". Neste modelo do Oralismo Puro, os alunos eram nivelados pelo seu grau de surdez.

Foram criadas ainda outras três escolas orais e auditivas no Espírito Santo: Vila Velha, Cachoeiro de Itapemirim e Colatina. Além das escolas especializadas, também existiam classes especiais em escolas regulares, como em Mimoso do Sul. O treinamento oral e auditivo, realizado nestas instituições, era a condição primária para que mais tarde, os alunos, pudessem ingressar na escola regular.

A partir da década de 1980, o método Perdoncini, uma especialização dentro do método oral, passa a ser o foco na educação de surdos no ES. A professora Álpia Couto-Lenzi era umas das referências neste método no Brasil e era a responsável pelas formações de professores realizadas no Espírito Santo.

Os últimos cursos baseados neste método, ministrados pela professora Álpia CoutoLenzi, aconteceram em 2000, 2001, 2002 e 2003. Logo após essas datas a Lei de LIBRAS 10.436/02 é publicada, dando início a uma virada na educação de surdos no Brasil.

A professora Álpia Couto sempre foi vista como sendo a voz máxima da educação de surdos no Espírito Santo, devido a sua experiência e formação. O que muitos não acreditavam acabou acontecendo, outras possibilidades, diferentes do que ela trazia como método foram sendo abordadas em nosso estado. 


\section{A virada da Língua de Sinais}

Apesar do primeiro curso promovido pelo MEC ter sido de cunho oralista e ter acorrido na década de 1980, foi neste contexto que se iniciaram os debates acerca da oralidade $\mathrm{x}$ gestualidade. Tudo isso por conta da chegada da vertente da Comunicação Total. Este foi um momento de dualidade, pois, por um lado eram ministrados cursos de capacitação com grandes nomes do Oralismo, como o francês Guy Perdoncini, e por outro alguns representeantes do INES viajaram para os Estados Unidos com o intuito de conhecer a Gallaudet College. Ainda em 1985, foi ministrado o primiero curso de língua de sinais por dois ex-alunos surdos, um do INES e outro do Instituto Santa Terezinha de São Paulo. Esta década de 1980 foi marcada pela transição entre os três métodos: Oralismo, Comunicação Total e o uso da Língua de Sinais para a instrução dos surdos. Uma pesquisa foi organizada dentro do Instituto com a finalidade de demonstrar o desenvolvimento dos alunos nesses três métodos. Os pais das crianças que optavam por qual método seus filhos seriam educados. Isso tudo movimentou o Instituto com outras demandas, uma vez que os pais que inscrevessem seus filhos nas classes que utilizavam língua de sinais, deveriam fazer o curso.

Já na década de 1990, o Instituto passa por uma situação muito dramática, quando sofreu uma intervenção do então ministro da Educação, na época do governo Collor, Carlos Chiarelli. Essa intervenção resultou no afastamento da então diretora Lenita, o que ocasionou grande desolamento entre os alunos e funcionários.

Segundo Rocha (2008), esse fato resultou em uma movimentação interna dos estudantes. A década de 1990 é marcada pela criação do Grêmio Estudantil em 1993, que impulsionou a luta ela utilização da língua de sinais em sala.

Esses movimentos atrelados a consolidação da Federação Nacional de Educação e Integração dos Surdos - FENEIS ${ }^{32}$ resultou na origem do movimento surdo em prol

32 Em 1977 foi fundada a Federação Nacional de Educação e Integração dos Deficientes-Autivos - FENEIDA, 
da utilização da língua de sinais como língua de instrução para os surdos nas salas de aula.

A culminância dessa virada aconteceu no ano de 2002, quando foi aprovada pelo então presidente Fernando Henrique Cardoso a Lei 10.436, também conhecida como a Lei de LIBRAS, que determinou que a Língua Brasileira de Sinais - LIBRAS, a partir da aprovação desta Lei, tornava-se um instrumento de comunicação das pessoas surdas, sendo reconhecido de forma oficial como língua em todo o território nacional.

Em seu texto original a lei 10.436/02 diz que:

Art. 10 É reconhecida como meio legal de comunicação e expressão a Língua Brasileira de Sinais - Libras e outros recursos de expressão a ela associados.

Parágrafo único. Entende-se como Língua Brasileira de Sinais - Libras a forma de comunicação e expressão, em que o sistema linguístico de natureza visual-motora, com estrutura gramatical própria, constituem um sistema linguístico de transmissão de ideias e fatos, oriundos de comunidades de pessoas surdas do Brasil. ${ }^{33}$ (BRASIL, 2002, p.01)

Assim, a Lei reconhece a Língua de Sinais, abrindo possibilidade para que os surdos alcançassem outra possibilidade de aprendizado através de outra metodologia de trabalho. Contudo, a provação da Lei de LIBRAS e posteriormente a aprovação do Decreto 5626/05 que regulamenta essa lei, não mudaram automaticamente a estrutura educacional do país em relação aos surdos. Todas as conquistas vieram por meio dos movimentos surdos.

Anteriormente sinalizamos a respeito da fundação da FENEIS na década de 1980 e

com o intuito de atender a todas as pessoas surdas do pais. Contudo a FENEIDA era formada apenas por ouvintes. Como reação a esta exclusão, em 1983 foi fundada a Comissão de Luta pelos Direitos dos Surdos, com o intuito de combater a hegemonia ouvinte presente na FENEIDA. Em 1987, num movimento de contestação a essa ordem, foi feita uma assembleia que reviu o estatuto da FENEIDA, nesta reunião, foram acordadas novas diretrizes para a instituição que acabou transformando-a na Federação Nacional de Educação e Integração do Surdo - FENEIS.

33 Disponível em : http://www.libras.org.br/leilibras.php 
do movimento dos alunos surdos dentro do INES através do grêmio estudantil na década de 1990. Contudo, os movimentos surdos de Associações de Surdos são mais antigos ${ }^{34}$. E foi dentro de espaços como as associações de surdos e de forma escondida nas escolas de surdos, que a língua de sinais sobreviveu ao século $X X$, século do oralismo no Brasil.

O reconhecimento da língua de sinais se dá por meio de uma pressão social feita pelos surdos na sociedade civil. Esse movimento ganha força na década de 1990 com uma série de eventos acadêmicos voltados para a educação e inclusão dos surdos. O primeiro deles ocorre no Rio de Janeiro.

\begin{abstract}
Em 1993, a Universidade Federal do Rio de Janeiro(UFRJ) através do grupo de pesquisa "Estudo da LIBRAS, Aquisição da Linguagem e Aplicação à Educação de Surdos", coordenado pela professora Lucinda Ferreira, organizou o II Congresso Latino Americano de Bilinguismo ( Língua de Sinais / Língua Oral ) para Surdos, no período de 12 a 17 de setembro de 1993, no local Hotel Copa D'Or no Rio de Janeiro . Houve, durante o congresso, um mini-curso com o professor Sueco Mats Jonsson sobre a metodologia de ensino de Língua de Sinais Sueca. Anterior a esse congresso, ocorreu no período de 17 de agosto a 10 de setembro de 1993, um outro mini-curso ministrado pelo professor Ken (surdo americano) e pela professora e intérprete Cherry (ouvinte). Durante uma semana foram abordados temas sobre a metodologia de ensino da American Sign Language (ASL) para os surdos brasileiros e sobre a interpretação da ASL para os intérpretes brasileiros. (MONTEIRO, 2006, p.07)
\end{abstract}

Este movimento surge dos debates regionais que estavam ocorrendo no Brasil, principalmente no Rio de Janeiro, por ser o estado onde esta situado o INES.

Contudo, surge no sul do país outro grupo disposto a discutir as questões relacionadas à surdez o Núcleo de Pesquisa em Políticas de Educação para Surdos (NUPPES), sob coordenação do professor Carlos Skliar, este núcleo foi responsável pelo fomento de pesquisas nas questões relativas à surdez e também na ampliação do debate sobre este tema. Este núcleo estava ligado a Universidade Federal do Rio

34 Alguns exemplos de Associações de Surdos antigas do Brasil: Sociedade dos Surdos do Rio Grande do Sul ( SSRS ), com 50 anos de existência; Associação dos Surdos de São Paulo ( ASSP ), com 55 anos; Associação dos Surdos de Londrina ( ASSL ), com 40 anos; Associação de Surdos de Goiânia ( ASG ), com 37 anos; Associação de Surdos de Minas Gerais ( ASMG ), com 56 anos; Sociedade dos Surdos de Belo Horizonte ( SSBH ); 
Grande do Sul (UFRGS) e pertencia ao Programa de Pós-graduação em Educação desta instituição. O NUPPES foi responsável por várias ações, dentre elas podemos destacar a sua articulação com a FENEIS/RS para a realização do III Congresso Latino-Americano de Educação Bilíngue para Surdos em 1999. Sobre este congresso Monteiro (2006) diz

\begin{abstract}
Em 1999, a Pós Graduação em Educação da Faculdade de Educação da Universidade Federal do Rio Grande do Sul (UFRGS) em conjunto com o Núcleo de Pesquisas em Políticas Educacionais para Surdos e em parceria com a FENEIS do Rio Grande do Sul organizou o V Congresso Latino Americano de Educação Bilíngue para Surdos, de 21 a 24 de abril de 1999. Entretanto, antes desse congresso, vários grupos de trabalhos de pessoas surdas se uniram no Pré-Congresso ao V Congresso de Educação Bilíngue para Surdos, de 20 a 21 de abril de 1999, para a discussão das propostas para a formação do professor Surdo e da formação do intérprete de LIBRAS. (p.07)
\end{abstract}

Havia toda uma discussão na época com o intuito de descobrir quem seriam os atores que ocupariam os espaços dentro do que seria a tão sonhada escola bilíngue. Para tanto, muitas discussões foram sendo realizadas antes, durante e depois de eventos como o Congresso latino-Americano, todas com o intuito de direcionar quais seriam as atitudes a serem direcionadas pelo movimento. Foram várias as frentes, elas incluíam além da educação a saúde, o emprego e os direitos dos surdos enquanto cidadãos brasileiros.

Monteiro (2006) aponta que foi realizado em São Paulo, no ano de 2001, um forte movimento liderado pela FENEIS daquele estado em prol desses direitos

A primeira Conferencia dos Direitos e Cidadania dos Surdos do Estado de São Paulo (CONDISUR) foi realizada no dia 21 de abril de 2001 e apresentou propostas na conquista de seus direitos e exercício pleno da cidadania relacionado à educação, cultura, família, saúde, esportes, direitos e deveres, trabalho, Língua de Sinais, comunicação, associações e movimento do surdo. (p.08)

Assim, percebemos como o movimento surdo foi se espalhando nas diversas esferas sociais, apontando que os surdos necessitavam não só de políticas linguísticas que atendessem sua peculiaridade, mas também de espaço para 
articulação de seus direitos enquanto cidadãos e de posturas governamentais que pudessem contribuir para a formação do surdo cidadão para o exercício da cidadania e ara o mundo do trabalho.

Numa mão dupla que envolvia atender as demandas linguísticas dos surdos e formar uma força de trabalho qualificada para a promoção de todas essas ações que os surdos vislumbravam, foi realizado em 2001 o primeiro curso de formação de instrutores de LIBRAS. Foi uma ação conjunta do Ministério da Educação - MEC e da FENEIS. Nesta capacitação foram formados 80 instrutores surdos de vários estados brasileiros. Ainda no mesmo ano, o MEC em parceria com o INES promove o primeiro curso de professores/intérpretes, que teve como objetivo capacitar professores de várias regiões do Brasil a trabalhar os conteúdos do currículo utilizando a língua de sinais. Neste curso foram formados 54 professores/intérpretes.

Neste fluxo de ações promovidas por instituições de ensino superior em nome da pesquisa, movimentos sociais surdos e iniciativas governamentais, foi aprovada a Lei da LIBRAS n 10.436 no dia 24 de abril de 2002. Os anos que se seguiram, foram marcados pelas ações sociais e governamentais que culminaram com o decreto que regulamentou esta lei. Sobre este momento histórico Monteiro (2006) nos diz

\footnotetext{
Nos dias 16 e 21 de março de 2005, houve reuniões técnicas para a consulta pública da Regulamentação da LEI da LIBRAS na Secretaria de Educação Especial (SEESP/MEC) com a participação de Instituições e Universidades Públicas. As propostas de contribuição para a Regulamentação da LEI LIBRAS foram enviadas e aceitas até o dia 03 de abril à Casa Civil e essas foram finalmente aprovadas através do decreto lei de $n^{\circ} 5626$ do dia 22 de dezembro de 2005. (p.09)
}

Segundo Monteiro, esta foi uma vitória difícil. Foram discussões e debates cansativos até a aprovação do Decreto 5626/05. Contudo, o movimento surdo saiu vitorioso, tendo seus anseios respondidos através da aprovação desta lei.

Após este movimento de caráter nacional, destacamos ainda um movimento alavancado pelos surdos no Encontro de Surdos na Bahia, no ano de 2006. Neste 
encontro os surdos realizaram muitas discussões pertinentes à educação de surdos. Ao final deste movimento, os surdos redigiram uma carta denominada: "A Educação que nós surdos, queremos e temos direito" ${ }^{35}$.

Neste documento os surdos deixam evidentes os seus anseios e expõem severas críticas ao modelo da inclusão, que extingue as salas e escolas especiais e aponta para a matrícula de todos os alunos com "Necessidades Educativas Especiais" NEE, na rede regular de ensino. Os surdos problematizam que as políticas educacionais devem observar as diferenças culturais e linguísticas dos surdos.

\begin{abstract}
As políticas educacionais devem levar em consideração as diferenças e as situações individuais dos alunos surdos, enfatizando-se a necessidade de um movimento transformador da educação como um todo, não se referindo só ao processo de inclusão escolar, mas propondo alternativas que viabilizem a qualidade do ensino, através de propostas pedagógicas significativas. (Documento "A Educação que nós surdos, queremos e temos direito", 2006, p. 04)
\end{abstract}

Cabe ainda destacar que neste encontro, os surdos apontam 13 mudanças que devem ser respeitadas em relação as estruturas da escola, currículo e gestão, nas quais observamos muitos apontamentos que estão presentes no próprio Decreto 5626/05, mas que os surdos entenderam, na época, que não estavam sendo contemplados. Assim, destacamos os 13 pontos:

1. Direitos iguais para todos como base para uma sociedade mais justa e igualitária, como preconizam a Constituição Federal Brasileira e a Declaração de Salamanca, o Decreto 5626/2005 e a recomendação 01/2006 do CONADE encaminhada para o Conselho de Pessoas com Deficiência;

2. Reestruturar o currículo pedagógico para aproveitamento dos recursos pictóricos e de sinais, pois o currículo se encontra apenas adequado para estudantes ouvintes;

3. Implementar a Língua de Sinais nos currículos escolares;

4. Assegurar a presença do professor surdo e do intérprete profissional na sala de aula;

5. Alfabetizar crianças surdas através do Bilingüismo;

6. Participação política educacional das pessoas surdas nos processos de discussão e implementação de Leis, Decretos, etc.;

35 www.eusurdo.ufba.br/arquivos/educacao_surdos_querem.doc 
7. Oferecimento de vagas para professor surdo nas Instituições de Ensino, principalmente para o ensino da Língua de Sinais;

8. Garantia de acesso à cultura surda;

9. Construção de escola de surdos e creche para crianças surdas, com estrutura proporcional para tal;

10. Inserir nos programas educacionais, inclusive nos telejornais a legenda e janela de intérprete;

11. Formação diversificada e ampliação de cursos para surdos;

12. Assegurar 0 acesso a recursos tecnológicos que auxiliem no processo de aprendizagem dos alunos surdos, inclusive o painel de legenda em sala de aula para os alunos surdos que solicitarem;

13. Concursos públicos com garantia de $20 \%$ da reserva de vagas para surdos.

Ainda no ano de 2006 um grande passo foi dado em relação as políticas educacionais para surdos. Foram criados 09 polos do curso de Licenciatura em Letras/LIBRAS. Este curso tem como objetivo formar professores de LIBRAS licenciados. A princípio ele foi implementado na modalidade à distância pela Universidade Federal de Santa Catarina em 09 polos pelo Brasil:

\author{
Universidade de Brasília - Brasília / DF \\ Universidade Federal de Santa Catarina - Florianópolis / SC \\ Universidade Federal do Ceará - Fortaleza / CE \\ Centro Federal de Educação Tecnológica - Goiânia / GO \\ Universidade Federal do Amazonas - Manaus / AM \\ Instituto Nacional de Educação de Surdos - Rio de Janeiro / RJ \\ Universidade Federal da Bahia - Salvador / BA \\ Universidade Federal de Santa Maria - Santa Maria / RS \\ Universidade de São Paulo - São Paulo / SP ${ }^{36}$
}

Em 2008 o número de polos foi ampliado para 15:

\author{
Unicamp - Campinas / SP \\ Universidade Federal do Espírito Santo - Vitória / ES \\ Universidade Federal do Ceará - Fortaleza / CE \\ Instituto Federal do Rio Grande do Norte - Natal / RN \\ Centro Federal de Educação Tecnológica- Belo Horizonte / MG \\ Universidade Federal do Rio Grande do Sul - Porto Alegre / RS \\ Instituto Federal de Goias - Goiânia / GO \\ Universidade de Brasília - Brasília / DF \\ Universidade Federal da Bahia - Salvador / BA
}

36 Fonte: www.libras.ufsc.br 


\begin{abstract}
Universidade Federal de Santa Catarina - Florianópolis / SC
Universidade Federal do Paraná - Curitiba / PR

Universidade Federal da Grande Dourados - Dourados / MS

Universidade Federal de Pernambuco - Recife / PE

Instituto Nacional de Educação de Sudos - Rio de Janeiro / RJ

Universidade Federal do Pará - Belém / PA $^{37}$
\end{abstract}

Hoje o Letras/LIBRAS já conta com alguns cursos presenciais na Federal de Santa Catarina e no Instituto Federal de Goiás.

Muitos foram os avanços realizados na educação de surdos no período das décadas de 1990 e 2000, entretanto, essas mudanças serviram não só para beneficiar os surdos, mas elas também evidenciaram a real situação educacional dos surdos em nosso país. Com a aprovação da Lei de LIBRAS e do Decreto, muitos surdos que haviam abandonado a escola no passado retomam os seus estudos, gerando um grande contingente de estudantes surdos na modalidade de Jovens e Adultos.

Além disso, com as mudanças realizadas dentro das discussões do decreto, muitos estados não tiveram condições de arcar com o que a lei trazia de novo, o que fez com que a comunidade surda voltasse às ruas e aos plenários para debater o futuro dos surdos nosso país.

Assim, os movimentos sociais alavancados pela comunidade surda têm se manifestado diante da realidade educacional vivenciada pelos surdos no Brasil. Se no passado esses movimentos conquistaram a Lei de Libras, hoje outras manifestações estão acontecendo. Nos dias 19 e 20 de maio de 2011, cerca de 4.000 surdos reuniram-se em Brasília/DF para iniciar um movimento nacional em favor das Escolas Bilíngues para surdos. Desse movimento originou-se o "Setembro Azul", que movimentou os surdos de todo o Brasil. No mês de setembro, são comemoradas algumas datas importantes para a comunidade surda: 26 de setembro - Dia Nacional do Surdo, 30 de setembro - Dia Mundial dos Surdos e Dia do Intérprete. Por isso a escolha deste mês.

37 Fonte: www.libras.ufsc.br 
O "Setembro Azul" nasce como uma resposta dos surdos à não-contemplação de suas propostas dentro do Plano Nacional de Educação - PNE, que foi discutido pela Conferência Nacional de Educação - CONAE, realizada em 2010. A Federação Nacional de Educação e Integração dos Surdos - FENEIS, em conjunto com lideranças surdas em todo país ${ }^{38}$, apresenta uma contraproposta ao Ministério da Educação, com o intuito de que suas sugestões sejam contempladas, para que a educação dos surdos possa atender as expectativas dos surdos. É certo que ninguém melhor para dizer o que lhes é necessário do que eles próprios.

Uma das respostas dadas pelo governo ao movimento dos surdos foi o decreto $7611 / 11$ que revoga o antigo Decreto 6571/08 que determinava o fechamento das escolas especiais em detrimento da matrícula dos estudantes com Necessidade Educacionais Especiais nas escolas regulares. Com o novo decreto, a presidência da república aprovou a continuidade da existência das escolas especiais e a matrícula dupla de seus estudantes. Além disso, o decreto evidencia que no caso dos surdos serão respeitadas as disposições do Decreto 5626/05.

Art. 1으 $\mathrm{O}$ dever do Estado com a educação das pessoas público-alvo da educação especial será efetivado de acordo com as seguintes diretrizes:

I - garantia de um sistema educacional inclusivo em todos os níveis, sem discriminação e com base na igualdade de oportunidades;

II - aprendizado ao longo de toda a vida;

III - não exclusão do sistema educacional geral sob alegação de deficiência;

IV - garantia de ensino fundamental gratuito e compulsório, asseguradas adaptações razoáveis de acordo com as necessidades individuais;

38 O Movimento Surdo em Favor da Educação e Cultura Surda está articulado por uma Comissão Geral e comissões regionais em todos os estados brasileiros. Essas comissões constituídas, em sua maioria, por surdos possuem também ouvintes que apoiam os surdos e vêm lutando para que eles tenham suas reivindicações atendidas.

Nessas comissões, há surdos e ouvintes com formação acadêmica em diversas áreas tais como Educação, Linguística, Psicologia, Fonaudiologia, Serviço Social, sendo muitos doutores e mestres, professores de universidades, faculdades e de escolas da educação básica e de indígenas; instrutores e intérpretes de Libras; diretores e associados da federação, de confederações esportivas e das associações de surdos e familiares. Portanto, todas as pessoas que fazem parte desse movimento estão diretamente envolvidas com a educação, cultura, identidade e língua dos surdos brasileiros que vivem nos centros urbanos, municípios ou em aldeias indígenas (FENEIS, 2011, p.29). 
$\mathrm{V}$ - oferta de apoio necessário, no âmbito do sistema educacional geral, com vistas a facilitar sua efetiva educação;

VI - adoção de medidas de apoio individualizadas e efetivas, em ambientes que maximizem o desenvolvimento acadêmico e social, de acordo com a meta de inclusão plena;

VII - oferta de educação especial preferencialmente na rede regular de ensino; e

VIII - apoio técnico e financeiro pelo Poder Público às instituições privadas sem fins lucrativos, especializadas e com atuação exclusiva em educação especial.

$\S 1 \underline{0}$ Para fins deste Decreto, considera-se público-alvo da educação especial as pessoas com deficiência, com transtornos globais do desenvolvimento e com altas habilidades ou superdotação.

$\S 2 \underline{0}$ No caso dos estudantes surdos e com deficiência auditiva serão observadas as diretrizes e princípios dispostos no Decreto no 5.626, de 22 de dezembro de 2005. (BRASIL, Decreto 7611/2011)

Os surdos continuaram seu movimento neste ano de 2012. Foram três os pontos de culminância que podemos observar até os dias atuais: A comemoração dos 10 anos da lei de LIBRAS e a proposição de emendas feitas pelos surdos no Plano Nacional de Educação.

Na comemoração da Lei de LIBRAS em 24 de abril de 2012, os surdos se reuniram em Brasília em uma manifestação que comemorava o aniversário da lei, mas que reivindicava as escolas bilíngues para surdos. A seguir, temos o depoimento do Professor Surdo, Mestre em Educação Cláudio Mourão

\begin{abstract}
No dia 24 de abril de 2012, comemoramos $10^{\circ}$ aniversário da Lei da LIBRAS, tenho honra e orgulho que estive em terra política (Brasília/DF), para comemorar, onde havia teatros, palestras e os movimentos de surdos que vieram todos os Estados do Brasil, fomos ao rua entres os prédios de ministérios, para chama atenção ao povo político e inclusive entramos no Congresso Nacional. Como os Surdos Brasileiros tem as mãos gritam e queremos ESCOLA BILÍNGUE PARA SURDOS... Mais uma vez, meus parabéns aos Surdos Brasileiros, Lideres Surdos, Intérpretes e os profissionais na área de Educação de Surdos pela união na presença da terra política e comemoração $10^{\circ}$ aniversário da Lei de LIBRAS.
\end{abstract}

O depoimento do professor Cláudio ${ }^{39}$ demonstra a organização dos surdos frente as

39 Disponível em: http://cacaumourao.blogspot.com.br/2012/05/no-dia-24-de-abril-de-2012- 
questões referentes a questão das escolas bilíngues e também da efetivação de uma política educacional para os surdos que atenda suas demandas. O resultado desta organização foi no último dia 29 de maio de 2012, quando a Comissão Especial da Câmara de Deputados Federais em Brasília acatou as mudanças propostas pelos surdos para o novo PNE.

O movimento social surdo tem estado presente nas discussões sobre o PNE e sobre a implantação das escolas bilíngues para surdos, numa tentativa de poder contribuir para que os surdos de uma forma geral sejam atendidos. Existem alterações no texto que garantem a educação ao longo da vida e que dão sustentação para que os surdos que não frequentaram a escola no passado, possam agora, buscar sua formação para o mundo do trabalho. É muito importante salientar que essas medidas tem sido articuladas, inclusive sob liderança da FENEIS com esse intuito.

O último ponto de culminância que apontamos, tem relação com a implantação do Instituto Federal de Santa Catarina Bilíngue - Campus Palhoça. Esse IF teve sua sede inaugurada em setembro de 2012, contudo, ele já funciona em um espaço provisório. Neste instituto funcionam vários cursos profissionalizantes em várias modalidades.

\begin{abstract}
O Campus Palhoça - Bilíngue desenvolverá programas de qualificação profissional, de Educação de Jovens e Adultos profissionalizante, Ensino Técnico e Cursos de Tecnologia, voltados à potencialidade dos sujeitos surdos, inserindo-os no contexto do mercado de trabalho. Ainda relacionado aos aspectos profissionais, o Campus Palhoça - Bilíngue priorizará a formação de profissionais bilíngues, tanto na modalidade presencial como a distância, com vistas a diminuir a distância que se criou entre as comunidades surdas e os ouvintes. Nesse sentido, o desenvolvimento de programas nos Cursos Superiores e de Pós-Graduação desse Campus irá atender a uma demanda bastante significativa de pesquisa e de formação de profissionais da área, em todo o Brasil, tanto no que tange a área tecnológica, quanto a pedagógica. ${ }^{40}$
\end{abstract}

Assim, percebemos que a luta dos surdos tem gerado muitos frutos, contudo, a efetivação do direito à educação, com qualidade, ainda é um desafio, principalmente nas escolas inclusivas.

comemoramos.html

40 Informações disponíveis em www.palhoca.ifsc.edu.br 
A história dos surdos não acaba com a conquista dessas leis e decretos, tudo isso, foi à remissão por anos de lutas e movimentos. Cabe agora aos surdos lutar pela continuidade de ações que possam propiciar melhores condições de aprendizagem e permanência para este grupo nas redes de ensino.

Afinal, nem todos estão de acordo com a luta dos surdos pela escola bilíngue, o próprio Ministro da Educação Aloizio Mercadante já apontou sua posição contrária, afirmando que a criação de escolas bilíngues é uma forma de segregação ${ }^{41}$. No dia 31 de maio de 2012, ele afirma em entrevista que as escolas especiais são espaços de segregação, pois o atendimento deve ser complementar e não excludente.

E mais uma vez os surdos respondem com uma carta aberta assinada por sete doutores surdos que são professores de universidades brasileiras, na qual eles reafirmam que a escola bilíngue é fundamental para que os surdos possam ter acesso a educação de qualidade.

Várias pesquisas mostram que os surdos melhor incluídos socialmente são
os que estudam nas Escolas Bilíngues, que têm a Língua de Sinais
brasileira, sua língua materna, como primeira língua de convívio e instrução,
possibilitando o desenvolvimento da competência em Língua Portuguesa
escrita, como segunda língua para leitura, convivência social e aprendizado.
Não somos somente nós que defendemos essa tese. Reforçamos que há
um número relativamente grande de mestres e doutores, pesquisadores de
diversas áreas de conhecimento, além de professores de ensino básico e
superior, que identificam essa realidade e atuam nessa luta conosco. Todos
os pesquisadores sérios proclamam que as ESCOLAS BILÍNGUES PARA
SURDOS, cujas línguas de instrução e convívio são a Libras (L1) e o
Português escrito (L2), são os melhores espaços acadêmicos para a
aprendizagem e inclusão educacional de crianças e jovens surdos. (Carta
Aberta ao Ministro da Educação, p. 02)

Esta luta está bem longe de seu final, contudo, como vimos, os surdos tem se posicionado ao longo da história em defesa dos seus direitos e do exercício da sua cultura e sua língua.

41 Entrevista divulgada no site do MEC, acesso em http://portal.mec.gov.br/index.php?option=com_content\&view=noticias\&Itemid=86

42 Acesso em: https://docs.google.com/file/d/0B8A54snAq1jAQnBYdVRPYmg1VUk/edit?pli=1 


\section{CAPÍTULO 3 - SUJEITOS SURDOS = SUJEITOS DE DIREITOS}

Os sujeitos surdos, assim como os ouvintes, os negros, os gays e tantos outros que compõem a sociedade brasileira, devem ser assistidos por suas leis de forma abrangente, assim como todos os demais. Segundo a Constituição Brasileira, em seu artigo 205 - A educação, direito de todos e dever do Estado e da família, será promovida e incentivada com a colaboração da sociedade, visando ao pleno desenvolvimento da pessoa, seu preparo para o exercício da cidadania e sua qualificação para o trabalho (p.123).

O texto da Constituição Federal é claro, no entanto, muitos brasileiros enfrentam dificuldades na efetivação deste direito e o direito à educação faz-se fundamental ao acesso aos demais direitos. Pois a educação pode vir a ser uma oportunidade de ascensão social, inclusão, formação, acesso a cultura, em todos os seus níveis e para todos, desde a infância até a velhice. Assim, a contribuição de Raniere (2009), deixa muito evidente tais argumentos quando a autora analisa estas questões sob a ótica do direito.

\footnotetext{
Como se sabe, o direito à educação ocupa papel central no âmbito dos direitos humanos. É indispensável ao desenvolvimento e ao exercício dos demais direitos. Por dar acesso a outros direitos, ele se mostra, portanto, um instrumento fundamental, por meio do qual adultos e crianças marginalizados, econômica e socialmente, podem emancipar-se da pobreza e obter os recursos necessários à sua plena participação no meio social. (RANIERE, 2009, p. 09)
}

Contudo, apesar do tangenciamento de documentos e discussões acerca do direito à educação, esta ainda é uma questão problemática percebida nos contextos de vários países, apesar de ser uma discussão bem antiga. Uma outra questão que cabe salientar é que o modelo social no qual estamos inseridos preconiza como inclusão social a formação educacional, ou seja, dificilmente um cidadão conseguira atingir um sem o outro.

Historicamente muitos documentos já foram produzidos sobre esta temática e seus 
textos vem evoluindo de acordo com as novas roupagens que os governos vem se modelando, com o intuito de responder as demandas atuais. Todavia, percebemos, ainda, uma fragilidade na oferta da educação.

\section{Os compromissos internacionais e o direito à educação}

Muitas organizações internacionais tem se posicionado em relação ao não cumprimento da oferta de ensino em diversas partes do mundo. Uma prova disso é a confirmação contida no documento assinado em Senegal - O Compromisso de Dakar, em 2001, onde as discussões acerca desta temática são retomadas ${ }^{43}$. De fato, em nossa organização social atual, esse direito deve ser encarado de forma inalienável, pois ter o ensino básico e o profissionalizante, são condições mínimas de acesso ao mundo do trabalho. Por isso o caráter fundamental do acesso ao ensino.

Em nossa esfera social, uma pessoa que não consegue adentrar no mundo letrado e fazer parte dele, sofre grande preconceito social, pois a educação e apropriação da leitura são vistas como algo primordial pelos membros de nossa sociedade. Contudo, há uma incongruência nesta medida, pois em nosso país, ainda não existem condições de acesso e permanência para todos na escola. Assim, ao mesmo tempo em que a escola inclui, ela também exclui, quando não consegue garantir este direito fundamental.

O direito a educação em si, não se trata apenas do acesso aos conteúdos do currículo, mas a existência de uma política educacional concreta, que tenha como horizonte, garantir o direito de todos. Sobre este aspecto Caggiano (2009) aponta que

[...] vislumbra-se o direito à educação como conteúdo multifacetado, envolvendo não apenas o direito à instrução como um processo de desenvolvimento individual, mas, também o direito a uma política educacional, ou seja, a um conjunto de intervenções jurídicamente

43 Aqui é retomado o documento de Jomtien de 1990. 
organizadas e executadas em termos de um processo de formação da sociedade, visando oferecer aos integrantes da comunidade social instrumentos a alcançar seus fins. (CAGGIANO, 2009, p.23)

Além disso, este direito não está pautado apenas em si mesmo, mas também nas bases sociais que sustentam o nosso Estado, no que tange, a questão da igualdade, da existência, do ser e estar dos indivíduos em sociedade. O Brasil assinou várias cartas e acordos internacionais que tinham como compromisso principal a garantia do direito, acesso e permanência dentro dos sistemas de ensino. Um dos documentos que podemos citar é a Declaração Mundial sobre Educação para Todos em 09 de março de 1990, na Tailândia, na qual é reafirmado o compromisso com a educação.

Nesse sentido, a compreensão do termo TODOS deve ser entendida em sua totalidade, pois a palavra utilizada abrange as diferenças presentes em nossa sociedade. E na década de 1990, muitos grupos sociais emergiram, após anos de ditadura, lutando pelos seus direitos, para serem enxergados com o olhar dado a palavra TODOS. Assim, podemos incluir neste cenário a luta dos surdos anteriormente trabalhada neste texto, pois é na década de 1990 que o movimento surdo volta com força total provocando o que denominamos de "Virada da LIBRAS".

Reivindicando por seus direitos, muitos surdos destacaram-se dentro dos movimentos, principalmente as lideranças surdas forjadas dentro das associações de surdos. E assim como estes, outras entidades foram se manifestando em prol da construção de uma educação que realmente abarcasse todas as diferenças. O que não pode passar despercebido é o fato de que muitos surdos ficaram fora das escolas devido a sua não aptidão a oralidade, com isso, formou-se um grande número de surdos que ficaram defasados no quesito idade/série, o que os tornava além de surdos e terem uma demanda especializada, também sujeitos da Educação de Jovens e Adultos - EJA.

Assim, na década de 1990, foi possível ter de forma palpável, vários movimentos 
sociais que buscavam a efetivação das políticas que os acordos previam. Paiva (2009) aponta que este momento foi de grande movimentação social, principalmente das chamadas Organizações Não-Governamentais (Ongs), isso porque, por mais que o Brasil tivesse assinado o acordo de Jomtien (Tailândia) a preocupação em atender grupos como os jovens e adultos ainda estava sob a tutela desse tipo de organização, das Igrejas, Movimentos de bairro no caso dos surdos também não era diferente. Vieira-Machado (2012) em seu trabalho aborda que muitos professores de surdos também iniciaram seus trabalhos com surdos em instituições como Igrejas, por exemplo.

Deste modo, percebemos que tanto a EJA quanto a Educação de Surdos estavam aquém do que os compromissos que o Brasil havia assinado exigiam. Assim, entendemos que, por mais que o texto da Declaração Mundial sobre Educação para Todos tenha sido um esforço para trazer mudanças, ele é apenas uma recomendação. O que não gerou grandes mudanças de imediato.

Voltamos então ao nosso princípio constitucional maior: "Todos tem direito à educação". Este é um direito legalmente conquistado pelo cidadão brasileiro, contudo sabemos que muitos itens legais relacionados a educação de nosso país não são devidamente observados. Então, se tenho grupos que não tem seus direitos assistidos na forma da lei, tenho então uma situação ilegal. Sim, isto foi um fato muito recorrente na história da Educação do Brasil, uma vez que no texto elenco a todos, mas na prática apenas alguns são alcançados.

Historicamente isso tem se mostrado na História do Brasil, principalmente aos grupos sociais menos favorecidos. Culminando inclusive, nas lutas sociais por cotas, com o intuito de diminuir o impacto causado por anos de desigualdades sociais e oportunidades de acesso à educação, gerados ao longo de nossa História. 


\title{
A conquista da Lei de LIBRAS
}

No caso da Educação de Surdos, isso foi vivenciado através da conquista da Lei de LIBRAS 10.436/02 e do decreto 5626/05, nos quais os surdos não garantem cotas, mas conseguem garantir um modelo diferenciado de educação que possa atender as suas especificidades. No caso da EJA, a Lei de Diretrizes e Bases da Educação Nacional - LDBEN, Lei 9304/96, garante em dois artigos a presença da modalidade EJA na educação básica. Sobre este momento PAIVA (2009) diz

\begin{abstract}
Em dezembro de 1996, oito anos depois da promulgação constitucional, a LDBEN ( Lei 9394/96) regulamentou o direito à educação para todos. Sancionada depois de intensa disputa entre setores organizados, deputados e senadores, tanto nas comissões, quanto nos gabinetes, via seu texto final levado a termo, em manobra não regimental promovida pelo Congresso nacional para satisfazer o projeto do Executivo, pelas mãos do senador Darcy Ribeiro, nesse momento seriamente doente, que aceita por seu nome à lei da educação, como última homenagem ainda em vida. $O$ projeto substituído, dentre muitas mudanças em relação ao texto original negociado, reafirmava e buscava ordenar em dois artigos, 37 e 38, a educação de jovens e adultos, assim nomeada no Capítulo II, Seção V, abandonando de vez a perspectiva compensatória da antiga formulação do ensino supletivo, rompendo de vez com essa concepção/nominação. (PAIVA, 2009, p.197)
\end{abstract}

Apesar de incluir esses dois artigos em seus textos, assim como o principio de educação para todos, a LDBEN em si não foi suficiente para concretizar a implantação da modalidade de forma concisa, pois apesar de no texto existir algumas questões que salientam a especificidade do estudante jovem e adulto, 0 texto restringe a proposta da EJA aos exames, bem nos moldes tradicionais. Deixando de compreender o educando com suas experiências e saberes, que é o ponto de partida da EJA enquanto modalidade, se constitui. Numa concepção de oferta ampliada e não de exames esporádicos.

Outro ponto que Paiva (2009) aponta é sobre o acesso e a permanência, quando a autora problematiza que muitos programas como a merenda e o livro didático não estavam disponíveis para os adultos, apesar de a EJA fazer parte da Educação Básica. 
Todas essas questões põem em "xeque" 44 as condições de qualidade de ensino que a escola estava garantindo aos alunos. Assim, durante a década de 1990, neste período de adequação a LDBEN, a EJA sofreu com essas questões sinalizadas anteriormente. Tanto isso foi verdade que em 2000, em Dakar, todos os compromissos de Jomtien tiveram que ser reafirmados, pois muitos países não os alcançaram, inclusive o BRASIL.

Já na década de 2000, é possível encontrar um ponto de articulação legal entre a Educação de Surdos e a EJA, uma vez que a Política Nacional de Educação Especial na Perspectiva da Educação Inclusiva de 05 de junho de 2007, prevê a inclusão dos estudantes com Necessidades Educativas Especiais - NEE, nas escolas regulares. Neste caso, qual modalidade de ensino receberia os jovens e adultos surdos dentro da escola regular?

Evidentemente que seria a EJA, uma vez que as idades seriam equiparadas aos dos alunos desta modalidade. Assim, a EJA passou a receber não só os surdos, como também outros alunos com NEE. Afinal, estes estudantes não podem ter seu estatuto de jovem e adulto negado devido a sua NEE, nesta pesquisa, especificamente a surdez. Afinal, o direito à educação e a necessidade de acesso à cultura e ao conhecimento é uma direito de todos.

O Decreto 6571/08 definia que após a inclusão dos estudantes com NEE na rede regular, estes deveriam ser atendidos através das ações promovidas pelo Atendimento Educacional Especializado - AEE. Neste sentido, os estudantes jovens e adultos com NEE deveriam ser atendidos na própria escola, no contra turno para o trabalho do AEE.

Sendo os surdos jovens e adultos trabalhadores, como estes poderiam ser atendidos pelo $\mathrm{AEE}$, se durante o dia estes estudantes estariam envolvidos nas tarefas cotidianas como o trabalho, tarefas domésticas, filhos, dentre outras. Foi o

44 Xeque- lance de ataque ao rei numa partida de xadrez. 
que Paiva (2009) problematizou, garantiu-se o espaço para este estudante, mas os métodos não estavam adequados. Não e necessário um bibliografia própria da Educação Especial para compreender isso, a própria bibliografia da área de EJA dá conta de responder esta questão, uma vez que, os jovens e adultos ouvintes também sofreram com essas dificuldades, uma vez que se cria o espaço, mas não são garantidas as condições.

Assim, os surdos vão ganhando espaço dentro da EJA e esta, ganha força no Brasil, procurando atender àqueles que não puderam frequentar a escola no passado ou não puderam permanecer nela.

O diálogo entre a EJA e a Educação de surdos consolida-se quando no Fórum Nacional de Educação de Jovens e Adultos - ENEJA, em 2010, aparece pela primeira vez, na redação de seu relatório final, manifestações de professores e educandos solicitando a inclusão da LIBRAS e das práticas bilíngues como forma de garantir a inclusão do aluno surdo nesta modalidade.

[...] Importante, também, é garantir aos educandos que possuem algum tipo de atendimento especializado, profissionais qualificados para trabalhar com ele, como por exemplo, o educando surdo que precisa de um educador que domine a linguagem de sinais (LIBRAS), sem a necessidade de intérprete . (Relatório Final do XI ENEJA, 2010, p.08) ${ }^{45}$

Neste documento fica visível que não só os professores como também os movimentos sociais envolvidos com a EJA, em sua representação máxima, que é o fórum nacional, também estão preocupados em incluir os surdos nesta modalidade.

Como resultado das lutas surdas e de outros movimentos, o Decreto 7611/2011 revoga o Decreto 6571/2008. Neste decreto é possível perceber algumas alterações bem pontuais, que tornam mais viável a educação dos surdos em todas as modalidades de ensino, inclusive na EJA, uma vez que dentro de seu primeiro artigo é considerada a garantida educação ao longo da vida e em todos os níveis de

45 Disponível em : http://forumeja.org.br/brasil 
ensino.

Estas leis já foram citadas ao longo deste texto, contudo, aqui faz-se necessário uma nova abordagem das mesmas pois, ao mesmo tempo em que o decreto 7611/2011 é tratado como uma vitória do movimento surdo em outro momento deste texto, neste ponto especificamente, sinalizamos como ele torna-se fundamental para dialogar sobre a inclusão em diversas esferas de ensino. Assim, o objetivo de apontá-lo neste trecho do texto especificamente, é salientar como este decreto pode dialogar com EJA e as possibilidades de matrícula dos estudantes surdos nesta modalidade.

Assim, tanto a Educação de Surdos quanto a EJA devem ser vistas como possíveis respostas para as exclusões que os jovens e adultos surdos e ouvintes sofreram no passado. Através do acesso a educação, estes estudantes tem a oportunidade de alcançar a inclusão social, através dos estudos e também a formação profissional para serem incluídos no mundo do trabalho.

A questão da educação profissional tecnológica seria um outro diálogo a ser relacionado as áreas que são discutidas neste texto, uma vez que o objetivo da educação profissional também esta voltado para a inclusão dos estudantes, que passam por ela, no mundo do trabalho. Deste modo, pensar em um diálogo entre essas três áreas é trazer à tona possibilidades de transformação para estes educandos.

\section{A EJA, a EPT e a educação de surdos}

Ao pensar a Educação Profissional Tecnológica - EPT, como um espaço de inclusão dos jovens e adultos, sejam eles surdos, cegos, pobres, negros, trabalhadores, enfim, é pensar em oportunizar formação não só profissional, mas em uma dimensão cidadã, pois à medida que estes educandos passam pelo processo de retorno à escola e iniciam um novo caminho, isso abre o horizonte dessas pessoas, melhorando suas perspectivas para o futuro. 
Contudo, para que essa articulação seja possível é necessária uma nova perspectiva, pois as metodologias aplicadas as turmas regulares não devem ser reduzidas para estes grupos, mas sim repensadas com a finalidade de atender estes educandos com educação de qualidade.

No final da década de 1990 e início da década de 2000 várias discussões sobre esta temática foram travadas no âmbito nacional, debates estes que articulavam a respeito da necessidade da oferta de ensino para este público e também sobre a baixa escolaridade apresentada pela força de trabalho em nosso país. Paiva (2009) aponta que os dados trazidos pelo Ministério do Trabalho e Emprego neste período eram alarmantes e por isso era necessário pensar que o Ministério da Educação deveria rearticular as demandas da educação de adultos, pois a realidade da época, apresentada pelo MEC, não era a necessidade real destes cidadãos brasileiros.

Assim, o Parecer CNE 11/200046 vem com o objetivo de alavancar as demandas reais para este público, e apresenta como seriam enxergadas a partir de então as funções da EJA.

\footnotetext{
Reparadora ( que envolve a escolarização não conseguida quando criança) Equalizadora ( que cuida de pensar politicamente a necessidade de oferta maior para quem é mais desigual do ponto de vista da escolarização); e Qualificadora ( entendida esta como o verdadeiro sentido da EJA, por possibilitar o aprender por toda a vida, em processos de educação continuada). (PAIVA, 2009, p.205)
}

Nesta dimensão, articular esses três campos: EJA, EPT e Educação de Surdos proporciona o horizonte que tantos jovens e adultos surdos procuram, após anos de exclusão nos processos educativos devido aos métodos de ensino aplicados pela escola especial oralista.

Reparar o passado educacional dos surdos é uma necessidade social, afinal não Ihes foi dada alternativas de instrução de acordo com a aptidão de cada um. Assim,

46 Conselho Nacional de Educação - CNE 
diante das legislações existentes atualmente, é necessário que o governo viabilize ações consistentes que transcendam o AEE e avance na direção das políticas bilíngues almejadas pela comunidade surda em todo o país.

Equalizar as políticas de oferta de educação de qualidade para este grupo de forma que atenda suas demandas é uma responsabilidade do governo e de toda a população, afinal os surdos estão nas ruas clamando por isso. Neste texto foram citados vários movimentos atuais que evidenciam este anseio.

E por último, qualificar este grupo é dar um novo fôlego a essas pessoas, com o qual poderão sonhar outras formações, outros trabalhos, que não se limitem a atividades repetitivas em linhas de produção, ou subalternas, onde mesmo tendo qualificação profissional são vistos aquém dos ouvintes, o que ocasiona desânimo e falta de perspectivas para o futuro.

Assim, as três funções da EJA, pensadas em conjunto com a EPT e a Educação de Surdos tornam-se um desafio, afinal, sabemos que a consolidação do Capitalismo separou o trabalho do homem, transformando o trabalho em emprego, exigindo produtividade e segregando àqueles que não produzem como sistema espera, condicionando estas pessoas aos trabalhos braçais, separando-os completamente da possibilidade de desenvolvimento humano por completo, onde a sua formação intelectual daria subsídios para a atuação em que o seu conhecimento estaria atrelado as atividades desenvolvidas por estes, gerando não só a remuneração, mas também o exercício do conhecimento. Por isso que o retorno dessas pessoas à escola é algo primordial, para que outras perspectivas possam ser traçadas e vividas por elas.

Então, quando falamos da inclusão dos surdos, não podemos deixar de salientar essas relações, pois incluir não é somente abrir matrículas para o surdos jovens e adultos na modalidade EJA, mas garantir 0 atendimento as suas especificidades linguísticas e sua formação para o mundo do trabalho, ampliando as possibilidades 
através da EPT para àqueles que assim desejarem.

Lembrando que a questão não é somente a matrícula, mas também as condições de permanência desses estudantes na escola e para isso são necessárias mudanças que possam garantir essa inclusão. Sobre esta relação Bianchetti e Correia (2011) nos dizem que

\begin{abstract}
Como sabemos, condições dadas não significam ipso facto realidade concretizada. Assim percebemos que o não enquadramento num padrão previamente estabelecido ainda causa muito sofrimento àqueles que não se encaixam na considerada normalidade; os portadores de necessidades educativas especiais ainda estão à espera do efetivo respeito e atendimento às suas especiais necessidades e lutando por isso, a diferença, em muitos aspectos é concebida e tratada como deficiência, a despeito dos avanços inegáveis já concretizados; há conquistas no campo da linguagem, sem que necessariamente conheçam tradução na prática social ou, nas palavras de Amaral (1994, p.55) ${ }^{47}$, "talvez seja, realmente, mais fácil falar sobre do que olhar para". Os avanços técnicos não se fazem acompanhar em igual velocidade e amplitude por conquistas no campo social. (p.46)
\end{abstract}

Tomando com base a reflexão de Bianchetti e Correia, é possível entender que gerar condições só no campo discursivo não é suficiente, faz-se necessário unir discurso e prática, para que assim, através deste diálogo sejam possíveis a matrícula e a permanência destes educandos na rede de ensino, seja em qual modalidade for.

Afinal, se a pesquisa nos aponta uma quantidade significativa de leis e decretos que garantem o acesso e incluem essas pessoas no público a ser alcançado pelas práticas educativas, principalmente quando tomamos como base o princípio do direito e da democracia, essas condições necessitam ser criadas, para que os avanços sejam observados na prática, assim como estão presentes no discurso. Bianchetti e Correia (2011) apontam justamente essa incongruência entre prática e discurso existente em nossa esfera social.

Percebe-se assim que, quando nos situamos na esfera do potencial e das conquistas no campo científico e tecnológico e até da legislação, muito temos a comemorar. No entanto, no que depender da radicalização da

47 Citação de Bianchetti e Correia (2011), feita ao longo do texto, extraída da obra de AMARAL, L. A. Pensar a diferença/deficiência. Brasília: Corde (1994). 
democracia no tocante a tudo o que já está disponibilizado, continuaremos diante de uma situação em que falar de tarefas de Hércules ou de Atlas ${ }^{48}$ está longe de ser apenas figura retórica. (p.46)

Avançar, do discurso associado à prática, tem sido um grande desafio da inclusão. Em outros momentos deste texto muitos apontamentos foram feitos a respeito desta oposição teoria / prática existente na realidade do nosso país. Apontamos primeiramente o que Paiva (2009) problematizou acerca das práticas existentes dentro da EJA sobre o trabalho realizado com os educandos e agora mostramos 0 que Bianchetti e Correia nos falam sobre a inclusão das pessoas com NEE. Assim, uma conclusão sobre esta a realidade fica: a consolidação das leis e dos discursos tem se mostrado como uma grande dificuldade para a concretização das práticas inclusivas. E quando falamos em práticas, estas devem contemplar todos os sujeitos e não apenas aqueles que ingressam na escola na infância, pois estes sujeitos estão ai, passaram por um passado no qual sua permanência na escola foi prejudicada por algum motivo e hoje, eles também devem ser alvos das práticas inclusivas contemporâneas.

Assim, diálogos entre áreas que buscam a inclusão das pessoas excluídas, como a EJA, a EPT e a Educação de Surdos devem ser diálogos abertos, para que possam a partir dai construir práticas que favoreçam a inclusão dos surdos jovens e adultos no universo letrado e no mundo do trabalho. Pois sabemos que a exclusão desses sujeitos também está presente nas relações de trabalho, na sociedade, na escola, enfim, nas diversas esferas do nosso cotidiano, assim, dar acesso e garantir a permanência é diminuir os impactos da exclusão presentes na sociedade de modo geral.

Assim, damos continuidade ao nosso trabalho apresentando alguns exemplos de zonas de contato, onde essa relação Educação de Surdos, EJA e EPT se deram na Grande Vitória, objetivando responder o nosso problema de pesquisa.

48 Referência que Bianchetti (2011) faz aos desafios que estes personagens mitológicos gregos enfrentaram em suas histórias. 
Para tanto, traremos as histórias dos narradores que viveram essa experiência e com isso, tentamos trazer à tona os fatos para uma problematização que possa potencializar a EJA e a EPT como espaços onde o surdo possa chegar, a fim de garantir-lhes sua inclusão no mundo do trabalho. 


\section{CAPÍTULO 4 - A INCLUSÃO DOS SURDOS NO PROEJA: COMO OS NARRADORES CONTAM ESSA HISTÓRIA}

A partir das discussões feitas até aqui, nos propomos nesta parte do trabalho, contar um pouco sobre o processo de inclusão de três alunos surdos no Instituto Federal do Espírito Santo - Ifes, como alunos do Programa Nacional de Integração da Educação Profissional com a Educação Básica na Modalidade de Educação de Jovens e Adultos - Proeja.

O Proeja é um programa do governo federal que visa atender estudantes jovens e adultos que não puderam cursar o ensino médio na idade prevista. Este programa oferece cursos, nos quais os educandos com uma única matricula podem cursar o ensino médio e o profissionalizante, numa perspectiva integrada.

É no espaço do Proeja, no Ifes, nos Campi - Vitória e Serra, que se encontram as pessoas com as quais conversamos e registramos as suas narrativas sobre o percurso dos alunos surdos no Proeja

Como dito no capítulo teórico-metodológico, esta história foi escrita baseada em depoimentos de profissionais que participaram deste processo e também na história de um desses estudantes. O fato dos outros dois estarem ausentes, nos faz montar este "quebra-cabeça" sem suas contribuições. No entanto, penso que todas as pessoas com as quais tive a oportunidade de dialogar, apresentaram essa história de forma interessante e clara.

Seguindo a ideia de Ricouer (1997) de que através das gerações as histórias são contadas, nos dispomos a ouvir atentamente o que foi sinalizado por todos os participantes sobre os fatos ocorridos no Ifes a partir de 2007.

A história da inclusão dos surdos no Proeja no Espirito Santo inicia-se em 2007, com a entrada de Rafael, primeiro educando surdo neste programa, no Ifes de Vitoria. 
Posteriormente entraram Guilherme e José.

Lançaremos mão inicialmente dos depoimentos da intérprete Simone e dos professores Jorge e Lília, pois estes participaram da primeira etapa desses educandos no instituto. Simone foi a primeira intérprete contratada pelo Ifes.

\title{
Quando os surdos chegam ao Ifes - Campus Vitória
}

Em seu depoimento a intérprete Simone fala sobre duas experiências concomitantes que ela vivenciou que tem relação com o Proeja, uma no ensino fundamental, em uma escola da rede municipal de Vila Velha, como intérprete do Guilherme ${ }^{49}$ e outra como intérprete do Rafael no Proeja no Ifes. Como a experiência com Guilherme é bem interessante, pois conta a trajetória deste educando desde o ensino fundamental até sua entrada no Ifes, vamos começar por ela.

Segundo Simone, Guilherme era um estudante que tinha dificuldades em se relacionar com os colegas e professores. A intérprete evidencia que esses "comportamentos" tão mal vistos pela escola comum, estavam fundamentados no processo de exclusão e solidão que Guilherme vivia naquele contexto.

\begin{abstract}
"Então eu fui conversando com a escola, mostrando o porque daquele comportamento, né, da indisciplina dele. E comecei a interagir por meio de língua de sinais com ele, a partir dai ele foi ficando melhor em sala de aula. E eu, comecei a fazer um trabalho de conquista de espaço porque era tudo muito novo, tanto para o Guilherme, que não tinha essa experiência de ter um intérprete em sala de aula como para os professores que também não conheciam esta função, né. A partir dai, começamos a desenvolver um trabalho e Guilherme foi mudando sua realidade na escola, mudando seu comportamento, melhorando, ele começou a aprender".
\end{abstract}

Nessa interação Simone percebeu que Guilherme tinha condições de ir adiante em

49 Guilherme foi o segundo aluno surdo a entrar no Proeja - Ifes - Campus Vitória. Quando Simone o conheceu ele já dominava a Língua de Sinais, pois era integrado à comunidade surda. 
seus estudos, isso devido a seu potencial que agora, com a presença da intérprete e a interpretação das aulas, ele pode desenvolver de forma mais aprofundada: questionando os professores, tirando dúvidas, sendo avaliado com a mediação da intérprete, ou seja, tendo sua diferença respeitada. Sobre este momento Simone diz

\begin{abstract}
"Quando eu percebi que o Guilherme tinha um potencial, que precisava ser instigado, que precisava ser explorado, que havia oportunidade de um desenvolvimento legal, na área da aprendizagem, eu comecei a investir. Então, todos aqueles momentos da escola de reunião de pais, de conselho de classe, de que os alunos saíam mais cedo, por algum motivo, eu aproveitava esses momentos para continuar na escola com ele estudando os conteúdos da sala de aula, porque em sala de aula não dava tempo para concluir. $E$ assim, nós fomos trabalhando. E quando ele chegou no $9^{\circ}$ ano, eu cheguei para ele e disse: Guilherme, você já tem idade, você pode estudar no Proeja, no Ifes tem essa modalidade de ensino, e você pode, você já é um rapaz, você pode tentar a prova. E ele sempre me perguntava: como? Como que eu vou fazer a prova se eu não sei?
\end{abstract}

Começamos a utilizar esses momentos de aulas vagas e ele ia também ao contra-turno e eu trabalhava com ele, principalmente física, química e biologia, que eram as disciplinas mais complexas, isso também devido a restrição do vocabulário da língua de sinais, pois nestas áreas, ele ainda está em construção, então, era com estratégias de sobrevivência que combinávamos os sinais, para que ele compreendesse e apreendesse os conceitos que estava estudando e que faziam parte dos conteúdos, para serem estudados, para a efetivação da prova do processo seletivo do Ifes. Então eu comecei a trabalhar em cima daqueles conteúdos que poderiam cair na prova. E então chegou o dia, ele foi fazer a inscrição, a família foi junto, mas tinha resistência porque achava que ele não ia conseguir, porque ele era surdo, tinham uma visão minimizada do surdo enquanto seu potencial criador, seu potencial para se desenvolver. Então eu comecei a fazer um trabalho com a família.

"Então, ele foi, fez a prova e para a alegria, não surpresa, mas a alegria nossa, porque eu sabia, eu acreditava no potencial dele, que ele teria condições de se dar bem naquela prova, porque ele estudou então ele passou e iniciou uma nova jornada na vida dele, lá no Ifes”. 
A presença da intérprete propiciou a Guilherme o conhecimento sobre a existência do Proeja, e o seu trabalho de incentivo, fez com que ele se sentisse capaz de tentar a prova e alcançar um novo caminho para a sua formação, como de fato, ele o fez. Muitos surdos deixam de procurar outros espaços de formação por falta de conhecimento e informação ocasionado pelas barreiras linguísticas.

Assim, Rafael e Guilherme foram os primeiros surdos que chegaram ao Ifes como alunos do Proeja, numa tentativa de ali buscar sua formação para o mundo trabalho em uma outra perspectiva, bem diferente das que as pessoas estão acostumadas a ver as pessoas surdas.

Retomando o ponto inicial, continuaremos a conhecer a história de Simone e o processo inicial da chegada dos surdos ao Ifes e os primeiros contatos, pois a partir desse depoimento, ficaram claros os contornos que a inclusão dos surdos naquele espaço foi tomando.

Eu citei o Guilherme antes porque a minha trajetória enquanto intérprete iniciou com o Guilherme. Mas, na realidade, eu já trabalhava no CEFET-ES ${ }^{50}$ naquela época tá. Eu trabalhava com um surdo lá, que era o Rafael, um surdo que veio de outro estado. Então, como todas as línguas tem os seus regionalismos, ele utilizava muitos sinais diferentes, assim, ele queria que eu utilizasse os sinais que ele usava em São Paulo, ele não aceitava os sinais daqui. Então eu comecei a fazer um trabalho com ele, que ele teria que me ensinar os sinais de São Paulo, para que pudesse interagir com ele, mas que ele também deveria aprender, me respeitando, enquanto aprendizado, os sinais que eram feitos aqui no estado, então é uma troca, eu ensinava os sinais daqui e ele me ensinava os sinais da cultura paulista.

Inicialmente, Simone enfrentou dificuldades em relacionar-se com o educando

50 Em algumas entrevistas poderemos observar a menção ao CEFET-ES - Centro Federal de Educação Tecnológica do Espírito Santo, isso porque quando os surdos entraram naquele espaço, a instituição estava passando por uma reestruturação que culminou com mudança para Instituto Federal de Educação Ciência e Tecnologia do Espírito Santo - Ifes. 
Rafael, devido as questões que expõe em seu relato. Contudo, entendemos que essa dificuldade inicial se deu devido à inexistência de uma relação entre a intérprete e Rafael. Teske (2005) aborda justamente esta questão, quando ele diz que

As pessoas nascem dentro de um grupo, socializam-se com os pais, amigos, professores e outros. Individualmente e progressivamente os sujeitos aprendem sobre as normas dos valores da família e da comunidade, da sociedade na qual vivem, e sobre os objetos e tecnologias. (p.147)

Mesmo a relação de intérprete de LIBRAS e estudante surdo sendo considerada algo primordial em um ambiente escolar inclusivo, não significa que isso vai se dar de forma instantânea e natural. No início deste trabalho, mencionamos que, para Bakhtin (2010a) as relações dialógicas não são o tempo todo harmônicas.

Sobre essas relações entre os sujeitos, as identidades e as diferenças Thoma e Kraemer (2009) nos dizem que

\begin{abstract}
Somos sujeitos pretensamente autônomos, de direitos, sujeitos universais, sujeitos civis, espirituais, econômicos, sujeitos produtores de formas de ser e de estar no mundo, na relação com os outros e na relação de cada um consigo mesmo. Na e pela cultura, somos constituídos e convocados a assumir determinados modos de nos relacionar, de nos posicionar, de enfrentar as circunstâncias, modos de viver as experiências, de agir de definir nossas condutas. (p.258)
\end{abstract}

Assim, os estranhamentos iniciais, e as negociações que precisaram existir entre Simone e Rafael, são consideradas parte do processo. E como a própria Simone expôs em seu relato, este aspecto foi vencido, e no dia a dia da sala de aula, ela foi constituindo uma boa relação com Rafael. Foi como ela disse, no começo foi muito difícil, mas com o tempo as coisas foram melhorando.

Contudo, devido ao fato de ser a primeira intérprete a trabalhar na instituição, em muitas situações Simone sentiu que haviam coisas a serem pensadas ali, pois muitos professores não haviam se dado conta da surdez de seus educandos e das demandas de metodologia de trabalho diferenciado que eles deveriam fazer. 
No início desse trabalho lá no Ifes, eu fui assim, a pioneira lá como intérprete, eu enfrentei muitas dificuldades, muitas resistências, porque uma escola praticamente tradicional, quase que cem por cento tradicional, em que os professores não enxergavam que havia um intérprete e que esse intérprete estava lá porque havia um surdo. Me recordo até da primeira reunião de professores, quando um professor da disciplina de Português, quando foi citado, (e que eu me apresentei como intérprete, eu já atuava na sala de aula, nas aulas dele) ele disse, ele fez o seguinte enunciado: Gente, tem surdo na minha turma? Quem é o aluno surdo? Eu não conheço ele ainda, eu não sei, tem surdo lá? $E$ isso, eu o tempo todo traduzindo lá, tinha me apresentado, mas ele ainda não tinha percebido que tinha um aluno que não ouvia. $E$ que utilizava uma língua completamente diferente daquele contexto, que era a língua de sinais. Então, isso me chamou muita atenção.

A partir dessa fala de Simone, podemos perceber que talvez tenha faltado, por parte da escola uma organização prévia que promovesse a circulação dessa informação, da presença de educando surdo e das questões que os professores deveriam observar a partir da chegada de Rafael e posteriormente com Guilherme e José.

Sabemos que para a promoção da inclusão no ambiente da escola, é necessário que os professores façam reuniões e formações para articular este processo. Assim, valendo-se de uma formação do Proeja, que tinha o seu momento estabelecido todas as segundas-feiras, Simone aproveitou este espaço para trocar com os professores algumas informações que pudessem amenizar estes momentos iniciais dentro do Ifes.

Lá, eu não sei se ainda tem, existia um programa de formação continuada, todas as segundas-feiras, a partir das quatro horas da tarde, onde todos os professores do Proeja se reuniam para discutir questões sobre educação, sobre as pesquisas que eram desenvolvidas lá dentro. $E$ eu, comecei a participar dessas reuniões, e comecei a marcar território, a partir do momento em que eu fui apresentada, eu comecei a explicar para os professores qual era a função que eu exercia lá dentro, o porque da presença desse intérprete, da necessidade. Apresentei a Lei 10.346 de 2002, apresentei o decreto 5626 de 
2005. Então assim, eu fui fazendo um trabalho com os professores para dar visibilidade de que o CEFET-ES, na época, não estavam aceitando o surdo na escola e tendo em sala de aula um aluno surdo e tendo esse profissional lá dentro, não simplesmente porque passou num processo seletivo, mas que esse profissional estava lá dentro atendendo a uma determinação legal, como um direito desse aluno.

O que Simone faz vai além de sua função como intérprete educacional ${ }^{51}$, mas não foge ao papel do intérprete enquanto um profissional que conhece a língua e a cultura surda e que está na escola para exercer um trabalho colaborativo com todos os profissionais da educação da instituição, para a inclusão do educando surdo. Assim, entendemos que sua disposição em articular com os professores foi de fundamental importância para as mudanças paradigmáticas que vamos observar nas falas a seguir.

Esse momento pra mim, assim, é o momento que eu considero de grande importância nesta trajetória, porque eu não estava ali apenas, como uma profissional para fazer interpretação, mas como professora que sou, e entendo que para estar numa sala de aula é necessário um conhecimento prévio, já que eu não detinha os conhecimentos específicos, das áreas de todas as disciplinas, porque isso cabe a cada professor. Então eu comecei, nessas reuniões, a solicitar aos professores, um tempo no planejamento deles, eu marcava previamente, em momento que fosse fora do horário de aula, e ali, eu fazia um trabalho individualizado e colaborativo. Pois com os planejamentos, era possível pesquisar os sinais que eu iria utilizar em sala de aula.

Percebemos aqui o início de uma possível articulação entre professores e intérprete para propiciar um processo educativo que contemplasse algumas questões, para que assim os surdos pudessem compreender melhor os conteúdos ministrados.

A intérprete menciona que aproveitou os espaços de formação do Proeja para

51 Segundo Lacerda (2009), o intérprete de Libras está na sala de aula para interpretar a Libras para o Português e do Português para a Libras, como também para mediar os processos discursivos entre professor e aluno, almejando a aprendizagem. (p.39) 
pensar meios de melhorar o seu trabalho e mediar melhor o aprendizado do aluno para o qual ela interpretava. Porque ela compreendia que, se os professores não participassem do processo, tudo ficaria mais difícil.

Segundo Lacerda (2009), a relação entre professor e intérprete é fundamental, pois é dessa troca que surgem as ideias necessárias para propiciar aos educandos surdos o acesso aos conteúdos. Assim, Lacerda nos diz

O professor é o responsável pelo planejamento das aulas, por decidir quais são os conteúdos adequados, pelo desenvolvimento e pela avaliação dos alunos, todavia o $\mathrm{IE}^{52}$ conhece bem os alunos surdos e a surdez e pode colaborar com o professor sugerindo atividades, indicando processos que foram mais complicados, trabalhando em parceria, visando a uma inclusão mais harmoniosa dos alunos surdos.(p.35)

Assim, como Lacerda (2009) sugere, Simone toma a iniciativa de propor aos professores um momento de troca, para que assim, ela pudesse se adiantar ao momento das aulas e preparar algumas estratégias de interpretação para que Rafael pudesse ter acesso ao conteúdo de forma mais clara. Ela menciona que muitos professores foram resistentes no início, mas que com o tempo essas relações foram se flexibilizando.

Veja bem, assim como em todas as instituições educacionais públicas, há uma rotatividade muito grande de professores contratados, e no Ifes não era diferente, porque muitos professores se aposentaram, efetivos. Então havia uma rotatividade grande de professores contratados considerável. Aqueles professores, mais antigos e efetivos, demonstravam uma resistência quanto à mudança, tinham sim, muitas resistências, mas ao longo do tempo, isso foi diminuindo, foi minimizando. $E$ os professores que chegavam, novos, mais recentes, já tinham uma visão diferente de inclusão, da presença desse aluno diferente, que aprende de uma forma diferente: linguisticamente, culturalmente, visualmente. Então, os professores contratados, tinham uma preocupação maior em estar preparando o material visual, de possibilitar esses momentos, na explicação dos conteúdos. 
Talvez, essa flexibilidade apontada por Simone, tenha relação com o acesso a formações sobre a inclusão que esses professores possivelmente possam ter vivenciado na graduação ou em outros espaços formativos. Ou mesmo por uma questão geracional, como Ricouer (1997) nos aponta, é a geração atual tomando o espaço das gerações mais antigas e atualizando os discursos dentro do tempo cósmico.

As pessoas de gerações contemporâneas são expostas as ideias de sua época. Assim, seria estranho se os professores mais antigos nunca aceitassem o aluno surdo, o que não aconteceu. Com o tempo e com a atualização dos discursos pela geração que vive esse novo paradigma, eles foram entrando em contato e aprendendo com a diferença surda no espaço da escola.

Deste modo, foi possível identificar dentro das práticas docentes e de outros momentos ocorridos dentro da escola, provocados pela presença dos alunos surdos, essas mudanças. Sobre isso Simone destaca a experiência nas aulas de Biologia, Química, Física e História.

Eu me lembro de uma professora de Biologia, ela assim, foi extremamente acolhedora, ela levava para o laboratório, ela dava toda a atenção aos alunos. Quando ela foi trabalhar a questão da célula, ela levou uma célula enorme, feita de material de silicone. E ali, ela deu uma atenção especial ao Rafael, e o Rafael compreendeu todo o funcionamento da célula. Nas aulas de química, nas aulas de biologia, nas aula de física, que exigia muito o visual, ele ia muito bem.

A professora de História também, quando ela percebeu quem era de fato esse aluno, e o comentário que os outros professores faziam acerca desse aluno e o desenvolvimento dele, ela entrou nessa dinâmica e ai ele deu muito bem conta da História também. Eu não senti muita dificuldade no aprendizado dele a partir do momento em que os professores compreenderam que o surdo, ele aprende por meio de experiências visuais 
E possível identificar a partir das falas de Simone que a dialogia proporcionada pelos momentos do planejamento individualizado com os professores, na formação do Proeja e com a marca diferencial do surdo dentro da escola, que na dialética dessas relações, foi possível o estabelecimento de atitudes que geraram mudanças.

Os surdos movimentaram a escola, não só no aspecto da presença do intérprete em sala, mas também na circulação da língua de sinais, porque Rafael foi o primeiro, mas Guilherme e José chegaram depois, ou seja, ocorreu o encontro dos pares linguísticos naquele espaço. Tudo isso movimentou a escola em uma direção em que não era mais suficiente as falas esporádicas da intérprete na formação do Proeja. Todos queriam cursos de formação, que realmente, abordassem as questões das diferenças em sala e também formações que dessem conta dos aspectos linguísticos dos surdos e o ensino da LIBRAS naquele espaço.

Nós montamos um projeto - Aprendendo LIBRAS no CEFET$E S$, de oficinas e esse projeto foi aceito e então nós demos início. Utilizando nessa ordem, como os personagens principais desse processo, nas oficinas, os dois surdos que tínhamos, o Rafael e o Guilherme. E foi assim, causou um impacto tremendo porque as oficinas aconteciam três vezes na semana, com duração de uma hora e não tinha vaga suficientes, porque os professores queriam, os funcionários queriam, os alunos queriam, a demanda era muito grande e nós não tínhamos como atender, devido a disponibilidade de horário.

Um fato interessante que aconteceu em um desses dias, nas oficinas, foi quando nas aulas de Português, o surdo tinha muita dificuldade, porque o professor trabalhava a literatura de uma forma que não possibilitava a acessibilidade ao surdo de compreender, então ele achava português muito difícil, ele reclamava. E na hora da chamada, o professor queria que ele respondesse presente, sendo que ele não ouvia o nome dele, e era eu enquanto intérprete que dizia presente. E, um belo dia, nas oficinas, esse professor não faltava, ele estava lá e quando nós começamos a prática do aprender os sinais, aprender as configurações, o alfabeto manual, esse professor teve muita dificuldade, muita dificuldade, ele não tinha aquela mobilidade com a mão, aquela facilidade de fazer a configuração e então o 
Rafael foi até ele, foi segurar mão na mão pra que ele pudesse fazer a configuração certa dos sinais. E ai o professor falou: isso é muito difícil, eu não consigo. Ai, Rafael disse pra ele: agora você consegue compreender e sentir a dificuldade que eu tenho para aprender português nas suas aulas, quando você quer que eu responda a chamada, se eu não ouço, eu dependo da intérprete para responder pra mim. Como você quer que eu leia um livro e explique aquele livro, se o livro está todo escrito na Língua Portuguesa e eu ainda não tenho o domínio da escrita do Português, porque ele é a minha segunda língua. A minha primeira língua é LIBRAS, agora você se coloca no meu lugar e foi muito interessante quando o Rafael disse: lá você é professor de Português e eu o aluno, e eu tenho dificuldade, aqui eu sou o professor de LIBRAS e você é o aluno, e você tem dificuldade.

Percebemos aqui que o professor foi provocado a, numa inversão epistemológica ${ }^{53}$, pensar sobre a sua prática em sala de aula. Afinal, ele pode vivenciar, através dessa oficina, o que o seu educando surdo vivenciava todos os dias, em todas as disciplinas. Foi provocado a pensar sobre o modo de enxergar o mundo que o seu educando tinha e assim, compreender a língua de sinais e a cultura surda como elementos que compunham aquele jovem que estava em sua sala. Obviamente, como Bakhtin (2010a) aponta que esse exercício exotópico de aproximação sugere uma possível imagem, mas nunca uma experiência igual a do sujeito que nos aproximamos. Mas aqui, o professor teve a oportunidade de pensar sobre quem é esse aluno surdo. Pensar na dimensão de uma experiência cultural.

Sinalizamos isso porque Simone nos apontou um final interessante sobre este momento.

A partir daquele dia, na aula seguinte deste professor, na hora da chamada, o professor solicitou que, na hora que ele chamasse o Rafael, que eu apontasse para ele, para que assim, Rafael observasse o professor fazendo a datilologia de seu nome, para que assim, em sua língua, levantando a sua mão, ele pudesse dizer presente.

53 Inversão epistemológica no sentido de que o conhecimento de uma língua como marjoritária, dominada pelo professor, é momentaneamente substituído pelo conhecimento de uma língua que ele não domina, no caso, a LIBRAS. 
Percebemos aqui, que o professor conseguiu compreender que o seu educando tinha outras experiências e assim, levando em consideração este aspecto, de forma muito interessante, ele consegue trazer para sua aula um pouco dessa cultura. É como Canclini (2007) nos diz "pode-se afirmar que a cultura abarca o conjunto dos processos sociais de significação ou, de um modo mais complexo, a cultura abarca o conjunto de processos sociais de produção, circulação e consumo da significação na vida social”. (p.41). Os encontros cotidianos entre a cultura surda e a cultura ouvinte vão delineando essas significações e produções sinalizadas por Canclini.

Ou seja, foi possível, a partir da experiência de aproximação cultural que o professor refletisse sobre os processos sociais daquele jovem e sua experiência visual sobre o mundo, e compreendesse assim que, a cultura surda abarca questões diferentes da cultura ouvinte.

\section{Sinalizando as experiências docentes no Campus Vitória}

Como apresentado no item anterior, os surdos causaram um movimento dentro do Ifes, o que gerou uma série de novidades que até então não existiam na escola. Essas mudanças provocaram nos professores uma sensação de que era necessário repensar suas práticas dentro daquele contexto. Trazemos para exemplificar este momento, o depoimento da professora Lília, de História. Essa professora traz um relato muito interessante para este trabalho, pois além de ter que dar conta das questões referentes aos alunos surdos, ela também precisou compreender as diferenças dos sujeitos jovens e adultos com os quais ela ia se relacionar, pois havia sido contratada para trabalhar com os educandos do Proeja, só que não possuía formação para tal.

"Eu fui professora de História no Ifes entre os anos de 2007 e 2009, as primeiras turmas com as quais eu trabalhei foram as turmas que tinham os alunos surdos. $O$ primeiro aluno que tive contato, foi o Rafael, ele tava no segundo módulo naquele momento. Eu senti que a escola já tinha passado por um certo 
movimento, com a entrada dele. Então, já acontecia, curso de LIBRAS para os professores e funcionários que trabalhavam lá, tinha a questão das intérpretes que trabalhavam com ele também. Eu fiquei muito, não só no início, mas durante todo o processo, eu fiquei muito receosa, porque eu nunca tinha trabalhado, tinha pouca experiência na área de educação e nunca tinha trabalhado com aluno especial, e nunca nem tinha estudado sobre isso. Na graduação, pro currículo que eu passei, que era o de 2002, não tinha nenhuma disciplina que abordava essa questão, nem sobre a Educação de Jovens e Adultos que também era novidade para esse trabalho, então era tudo muito novo. Eu me sentia muito receosa, com medo de ficar excluindo $o$ aluno durante a aula. Durante 0 planejamento da aula eu pensava muito nele, apesar de ter cometido alguns deslizes, mas as intérpretes me ajudavam muito. No início era Simone e a Cláudia ${ }^{54}$. A Cláudia principalmente, eu mostrava o planejamento pra ele, como eu estava pensando em trabalhar, eu perguntava o que elas achavam. Perguntava se eu estava falando muito rápido pra elas interpretarem para ele.

É possível perceber nesta fala, a preocupação da professora em recuperar a sua formação em relação ao conhecimento dos surdos e da EJA e também em não excluir os estudantes ao longo de suas aulas. Entendemos que esta preocupação tem relação com a insegurança que a professora aponta, devido a sua falta de experiência docente, e também por perceber a existência de um movimento de inclusão dentro da escola para garantir o direito à educação desses educandos. Tanto que, ela procura, a partir de seu ingresso na instituição, tecer um trabalho colaborativo com as intérpretes, trocando com elas os planejamentos e ideias.

Com o tempo, a relação entre a professora, as intérpretes e os educandos surdos, vai se naturalizando, de forma que as relações dialógicas vão ocorrendo dentro da sala de aula.

Na aula elas paravam e perguntavam: Lília, me explica tal termo para eu passar aqui pro Rafael. O Rafael tinha uma característica diferente, ele tinha uma formação sólida, diferentes dos demais alunos. Ele veio de São Paulo, então

54 Não foi possível gravar o depoimento da intérprete Cláudia, pois a mesma encontrava-se com problemas pessoas durante o período desta pesquisa. 
quando eu falava, ele participava, dizia que já conhecia o tema e interagia em sala de aula. Depois, eu trabalhei com o Guilherme, só que ele era bem diferente do Rafael, ele era mais na dele, mais fechado, ele não trocava muito. O período que eu trabalhei com ele, ele era um aluno muito faltoso.

Aqui, pela primeira vez, temos uma análise da visão de um docente sobre as diferenças entre os dois educandos surdos. O que nos remete a fala inicial de Simone sobre as dificuldades de Guilherme, ainda no ensino fundamental. É importante evidenciar essa diferença, para marcar os processos educativos desses jovens. Em outros relatos aqui apresentados, temos a oportunidade de verificar que Rafael vem de outro estado e lá, ele estudava em uma escola de surdos, diferentemente de Guilherme, que no início deste capítulo, apontamos a experiência de Simone com ele em outra escola, e a intérprete sinalizou que este aluno ficava sozinho e sem interação com os alunos ouvintes.

O que Guilherme viveu é o que Thoma e Kraemer (2009) explicitam como proposta critica à educação inclusiva apenas como discurso, em nome de direitos universais, mas que não tencionam as questões de diversidade e diferença, pelo contrário, as transformam em sinônimos. Sobre isso as autoras nos dizem que

\footnotetext{
A proposta da educação inclusiva, em sua discursividade, captura como sinônimos os termos diferença e diversidade, em detrimento de direitos universais para os seres humanos. A condição humana se estabelece como elemento central das prerrogativas políticas, deixando as questões específicas de cultura, identidade, língua, para um segundo plano. (p.267)
}

Essa concepção metodológica do sistema educacional, onde Guilherme estudou, acarretou para ele dificuldades em se relacionar e problemas de compreensão dos conteúdos, devido ao seu afastamento de seus pares linguísticos e da solidão em sala de aula. Diferentemente de Rafael, que era integrado a comunidade surda em São Paulo e trouxe consigo o que a professora reconhece como formação sólida, inclusive, em relação aos demais educandos, ou seja, os ouvintes.

No fluxo dos movimentos ocasionados pela presença dos estudantes surdos no Ifes, 
a professora destaca a realização de formações e a sua participação nelas.

Durante esse processo, na escola teve uma série de cursos de inclusão, educação de surdos, educação de pessoas com deficiência visual, de diversidade em geral, isso ajudou bastante. Depois eu frequentei a oficina de LIBRAS, ali eu acho que eu aprendi muito, mais sobre a cultura, porque LIBRAS, eu já esqueci. Porque ali, nós tivemos a oportunidade de conviver com muitos alunos surdos, que não eram da escola, mas participavam da oficina e em outra postura, né, eles ensinando pra gente, então, foi uma experiência muito enriquecedora pra mim e pra instituição.

Podemos perceber que a professora consegue captar a diferença surda em sua dimensão cultural, e essa experiência, de ver os surdos dessa forma, não ocorreu dentro da sala de aula, mas no espaço da oficina de LIBRAS, onde ela pode ver vários surdos reunidos e falando sobre a sua cultura, ela viveu o que Canclini (2007) chama de "choque de significados na fronteira" (p.48), ou seja, ela criou uma interpretação sobre a cultura surda, a partir do momento em que exotopicamente, aproximou-se da fronteira, ou seja, de um grupo de surdos e não apenas de um surdo isolado em sala de aula.

Um outro ponto interessante na fala da professora Lília é o que ela chama de "dualidade entre o grupo de professores".

Desde que eu cheguei na escola, eu senti um dualismo, de um lado uma parte da equipe muito preocupada com essas questões, com as questões sobre os jovens e adultos, essa formação integral do aluno e a inclusão na escola, na instituição, no Ifes. E por outro lado, tinha um grupo que, ou era desinteressado, e ainda tinha um terceiro grupo que achava que ali não era o lugar deles. Então, esse era um conflito que eu percebia na escola trabalhando com educação de jovens e adultos e dentro dessa diversidade que a educação de jovens e adultos traz para a escola, porque além dos surdos, eu trabalhei com aluno travesti, gays, negros, cadeirantes, então de certa forma, isso balançou um pouco a escola.

O que a professora expõe aqui, é algo que Thoma e Kraemer (2009) apontam como 
sendo uma inquietude provocada pela presença do outro. E mais, pela falta de aproximação entre o "eu" e o "outro" existente nas instituições educacionais, porque garantir a presença das diferenças no espaço da escola, não significa que práticas inclusivas serão realizadas. É o que as autoras nos mostram

\begin{abstract}
Estamos na presença do outro, nos deparamos constantemente com o outro, a educação vem solicitando a participação desse outro, os espaços sociais pretendem estar preparados para receber o outro, mas um outro da mesmidade, um outro traduzido, descrito, inscrito nas malhas dos saberes normalizadores. $O$ outro que tem sua posição garantida, desde que se permita ser moldado e desde que seja um outro medido. (p.268)
\end{abstract}

E pelo o que a professora nos relata, isso não acontecia. Porque eram muitas as diferenças que chegaram ao Ifes com o Proeja e muitos professores não estavam preparados para vivenciar essa transformação. Assim, é mais fácil, assumir a postura do desinteresse e da indiferença em relação a esses educandos. Uma vez que eles não conseguiam medir e adequar esses educandos às suas práticas de costume.

Outro depoimento muito interessante que conseguimos gravar foi o do professor Jorge, da disciplina de Filosofia. Isso porque seu depoimento apresenta uma preocupação muito forte sobre a interpretação que era feita em sala, não que ele suspeitasse da qualidade do serviço realizado pelas intérpretes, mas porque ele se preocupava com o volume de conhecimentos que elas tinham que dar conta em suas interpretações.

Uma das experiências que eu lembro nitidamente, foi em uma das aulas que eu estava dando, sobre essa questão da tradução, porque existem certas coisas que não dá para traduzir. Eu estava explicando um conceito, a aula era sobre filosofia antiga, e ai eu entrei no assunto sobre a Metafísica. Quando eu falei a palavra Metafísica, a intérprete que estava na sala, ela não entendeu que conceito era aquele, ela não conseguiu traduzir a expressão Metafísica. Ela então parou a aula e pediu: professor, o senhor pode explicar o que é esse conceito, ai eu tive que explicar pra ela, para ela traduzir para o aluno. Essa é uma questão conceitual. Então há os limites 
conceituais, dependendo da disciplina.

O que o professor Jorge aponta em seu relato, é uma questão que tem inquietado a área da educação de surdos, uma vez que o modelo inclusivo prevê que o surdo seja matriculado na escola regular e a única forma de incluí-lo neste espaço é contratando intérpretes. Obviamente, o decreto 5626/05 legisla sobre esta contratação, contudo, a preocupação do professor é legítima, uma vez que, por mais que o intérprete tenha formação na área da educação, é difícil para ele dominar todas as disciplinas. Uma forma de amenizar essa dificuldade é a realização das trocas com os professores e o trabalho colaborativo, contudo, não resolve o problema efetivamente.

E o que o professor Jorge problematiza não é só a questão conteudista, mas também a dimensão subjetiva da interpretação.

Teve uma das intérpretes que trabalhou com a tradução da química, com os termos técnicos da química, que segundo ela não tinham tradução, a língua de sinais não conseguia traduzir. Então ela não tinha como traduzir aquilo para o aluno. Isso é uma questão técnica terminológica. Mas há outras dimensões, da subjetividade da relação entre o professor e o aluno, que eu acho que o tradutor não dá conta, são próprios da convivência do aluno com o professor $A$ questão da emotividade, por exemplo, as vezes a expressão que você usa, vem carregado de significado pra você naquele momento e o tradutor, como ele não está na sua subjetividade, ele não consegue captar toda essa vivência, essa experiência.

Percebemos aqui a preocupação do professor em construir com o seu educando uma relação de proximidade, regada com os sentimentos subjetivos das relações sociais cotidianas. Entretanto, ele não consegue compreender como isso se dá, com a intérprete atuando entre ele e o educando.

A preocupação do professor coincide com o que Thoma e Kraemer (2009) apontam em seu texto. Segundo as autoras, a política atual entende que "o sujeito surdo, 
nomeado outro, diante dos discursos postos em prática por tal política, não requer nada além da língua, não necessita nada além de professores que conheçam um pouco da língua de sinais e sejam "bilíngues", ou de intérpretes nas aulas." (p.268)

Contudo, o professor, mesmo não sendo da área da educação de surdos, compreende que a dimensão do entendimento dos educandos vai além da interpretação, mas alcança patamares subjetivos, que dizem respeito ao que o professor sente em relação ao seu educando e que talvez as intérpretes não tenham como traduzir isso, porque este é um sentimento vivenciado pelo professor. É o que Bakhtin (2010a) sugere quando aponta que ouvir dizer, não é o mesmo que sentir o atravessamento da experiência.

Assim, este professor compreende que a questão do surdo transcende a questão linguística e que a mesma se caracteriza como uma questão social e cultural.

Durante a pesquisa, percebemos a existência de uma preocupação dos intérpretes em conseguir interpretar as aulas, compreender os termos técnicos da Informática, que era o curso dos três educandos surdos. Mas, o único professor que concentra a sua preocupação no ato interpretativo é o professor Jorge.

Então, eu sempre ficava pensando assim: entre o que eu falo, o que o intérprete entende e a forma como ele traduz e o aluno entende, são três sujeitos diferentes, com histórias diferentes, com formações diferentes, com experiências diferentes, essa é uma questão.

Compreendemos essa preocupação como algo positivo, pois, para este professor, o fato de ter um intérprete em sala de aula não significava que o educando estava entendendo o seu conteúdo. $E$ isso é importante, pois muitos professores não só não se preocupavam como acreditavam que este entendimento, por parte do educando surdo, era uma responsabilidade do intérprete.

Percebemos aqui o quanto o professor prezava para o desenvolvimento desses 
educandos enquanto seres autônomos, sendo que estes jovens deveriam ser enxergados como tal e não apenas pelo viés da falta.

Um outro ponto que o professor problematiza, é sobre a formação dos intérpretes, pois ele não consegue entender que um mesmo profissional, possa dar conta de traduções tão específicas, dentro dos contextos diferenciados das disciplinas.

A outra questão é a formação desse intérprete, você é intérprete, mas dependendo do conteúdo de Química, Filosofia, Sociologia, você precisa compreender bem aquilo pra poder traduzir, não é isso? Então, como você vai compreender bem de Física, Química, Matemática, Filosofia, Sociologia, Você tem que ser um expert em tudo isso? Pra você traduzir? Se você não entende, sua tradução é só literal, não avança mais do que isso, não é carregada de vivência e experiência.

Sobre isso Ricouer (2011) nos dá uma importante contribuição para pensar quando o autor diz que ora, na falta de descrição completa, só temos pontos de vista, perspectivas, visões parciais de mundo. (p.53) Ou seja, o risco de algumas interpretações terem sido feitas naquele contexto, apenas de forma superficial é muito grande.

Mas, cabe lembrar que isso é uma deficiência do sistema, quando propõe políticas inclusivas, mas faltam articulações nas instituições de ensino para prever esse tipo de situação e tentar contornar de alguma forma, como por exemplo, propiciar uma formação aprofundada para os professores, de modo que estes possam em conjunto com os intérpretes, encontrar formas de unir o conhecimento científico ao conhecimento linguístico e propiciar de forma clara, as explicações dos conteúdos para os surdos.

Essa também é uma preocupação concernente as áreas de EJA e EPT, pois percebemos que em todos os relatos, essas foram deixadas em segundo plano e a questão da surdez criou uma sombra muita grande sobre elas, pois os professores estavam mais preocupados com o fato dos educandos serem surdos do que com 
qualquer outra possível questão.

\section{O fantasma de José e a partida de Guilherme}

José foi o único estudante surdo que passou pelo lfes que conseguimos entrevistar. Contudo, com exceção da intérprete Simone, nenhum outro profissional que deu seu depoimento para esta pesquisa, mencionou José.

Conseguimos localizar José através de uma rede social, inclusive, bem a tempo, pois o mesmo estava de mudança para o estado de Goiás, por ter passado no vestibular da Universidade Federal de Goiás - UFG, para o curso de Letras/Português.

José, concedeu-nos seu depoimento, na ocasião, abordou aspectos inerentes ao seu passado escolar e as dificuldades com a Língua Portuguesa.

Meu nome e José, este é o meu nome visual. Em relação a minha história de vida educacional, bem no passado, eu estudava em escolas comuns e eu não tinha intérprete. Eu cresci sem desenvolver uma comunicação efetiva com os meus professores e colegas de sala, e essa situação fazia com que eu tivesse muitas dúvidas, eu não entendia quase nada. Alguns colegas que sentavam próximos a mim, tentavam me ajudar, mostrando, apontando no caderno como fazer os exercícios. Mas era uma relação que eu tinha com meus colegas, com os professores eu não tinha relações de troca de conhecimentos, isso porque, com os meus colegas eu tinha uma certa comunicação, mas com os professores não. Essa situação continuou a existir na minha vida, mais ao menos até meus 16 anos, nesse percurso, fiquei reprovado duas vezes. Meus colegas que me ajudavam, passaram de ano e eu fiquei para trás, o que fez com que tudo ficasse mais difícil. Eu conseguia passar em matemática, porque é mais visual e fazia contas utilizando minhas mãos, mas nas outras disciplinas: Português, História, Geografia, ou seja, disciplinas que dependiam de leitura e escrita, eu nunca conseguia passar, porque eu não sabia ler bem e não conhecia muitas das palavras utilizadas pelos professores. 
Mesmo estando desassociado das falas dos profissionais em relação aos outros educandos surdos, percebemos que José possuía dificuldades semelhantes a dos outros surdos, ou seja, dificuldades com o Português escrito e com a comunicação de modo geral, pois, por estudar em uma escola regular, ele não possuía intérprete. Considerando a idade atual de José, 24 anos, na sua infância seria impossível a presença de um intérprete em sala, uma vez que a metodologia vigente na década de 1980 e 1990 ainda era o Oralismo.

Eu frequentava o atendimento no contra-turno na Escola Oral e Auditiva. Nessa época, ainda não era permitido o uso da LIBRAS, os professores ensinavam apenas o treino da oralidade, eles mandavam colocarmos as mãos para trás e treinarmos apenas a fala. Não nos ajudavam com as dúvidas sobre as disciplinas de Português, História e Geografia. Então, quando eu voltava para a escola, como não conseguia aprender, eu colava dos meus colegas para conseguir fazer as atividades, eu ficava descansado, esperando meus colegas terminarem, eu copiava tudo e entregava para os professores e assim, fui conseguindo passar de ano. Isso desde a $1^{a}$ série até a $8^{a}$ série. Nunca tive intérprete, nunca entendi o que os meus professores ensinavam em sala. Só conseguia aprender matemática.

Eu queria utilizar LIBRAS, mas as pessoas queriam apenas que eu oralizasse. Assim, eu não conseguia entender.

É possível perceber na fala de José o quão era complicada sua comunicação no espaço da escola, a mesma vivenciada por Guilherme apontada anteriormente. E que foram solucionadas, em parte, a partir do momento em que passaram a estudar com a presença do intérprete em sala de aula.

Quando eu passei para o ensino médio, eu fui estudar na Escola Estadual, chegando lá, pela primeira vez, eu tive um intérprete em sala, ficou mais fácil de compreender o que os professores ensinavam. Eu estava com 17 anos, quando aprendi Gramática pela primeira vez. Parece até que eu voltei no tempo, nas séries iniciais e comecei a relacionar as palavras aos sinais, e assim, comecei a entender. Fui aprendendo, as palavras, depois a organizar frases e por último os textos. 
O que a presença do intérprete propicia a José é algo completamente novo, pois pela primeira vez, ele consegue aprender Português, o que o deixou muito feliz. Acreditamos que esse novo horizonte ocasionado pela mudança de escola e a presença de intérprete e outros surdos na Escola Estadual proporcionou ao José uma nova realidade, dimensionada na dialogia.

Segundo José, tudo isso o incentivou a tentar a prova de seleção para o Proeja, pois passou a sentir-se capaz de dar continuidade aos seus estudos. Entretanto, ele não sabia que, esta nova oportunidade, seria para ele, uma grande decepção.

Quando eu passei para o segundo ano, eu fiz a prova do Ifes para entrar no curso de Informática do Proeja. Eu passei na prova, mas era tudo muito difícil, as palavras, os conteúdos. Eu tinha uma intérprete, mas mesmo assim, eu tinha muitas dificuldades. Eu fazia as provas, e quando os professores devolviam, estava tudo errado. Então eu abandonei. Contudo, minha família e meus amigos ficaram me incentivando, dizendo que o Ifes era muito bom, que era muito importante para o meu futuro profissional, então, no período seguinte, eu tentei voltar, mas já era tarde demais, eu tinha muitas faltas. Eu até tentei fazer a prova de ingresso novamente, mas eu fiquei reprovado. Então, eu desisti.

José não conseguiu acompanhar o ritmo do Ifes, devido a dupla jornada estudantil, porque ele continuou a fazer o ensino médio que ele já havia começado na Escola Estadual e o curso de Informática do Proeja. Não ficou claro em seu depoimento, o por que do abandono do curso, uma vez que, mesmo sendo difícil, ela tinha um suporte e ele nem tentou, simplesmente abandonou. Talvez por isso, as pessoas nunca lembram de citá-lo.

Segundo a intérprete Simone, José era muito faltoso, o que contribuiu para as suas dificuldades de compreensão e realização das atividades propostas, por estar sempre atrasado. Segundo a intérprete, ele estudava em duas escolas, uma de ensino médio regular pela manhã e no Ifes à tarde. 
Felizmente o futuro reservou um caminho interessante para José, pois a disciplina com a qual ele tinha tantos problemas - Português, agora o convoca para cursar, em outro estado, um curso de graduação em Letras/Português na Pontifícia Universidade Católica de Goiás. José foi aprovado no vestibular de inverno desta universidade no mês de junho de 2012.

Por último, sinalizamos o falecimento do surdo Guilherme, vítima de uma bala perdida em seu bairro. Apesar de ainda constar como matriculado, Guilherme já havia abandonado o Ifes, por estar trabalhando e não conseguir conciliar o trabalho, o estudo e a distância do Ifes em relação a sua residência.

Cabe ressaltar que as relações entre trabalho e estudo dificultaram muito o percurso deste estudante no Ifes, pois o mesmo trabalhava em um fábrica e seus horários eram estipulados por escalas, o que prejudicava sua frequência as aulas.

\section{A segunda etapa: a chegada do surdo no Campus Serra}

No período em que os educandos surdos estudaram no Ifes, na modalidade do Proeja, a parte do curso referente ao ensino médio, era cursada no lfes Campus Vitória e a parte do curso referente a parte tecnológica em Informática, era feita no Campus Serra.

Como José havia sido desligado do curso e Guilherme falecido, o único estudante surdo que chegou a esta etapa do curso, foi o Rafael. Assim,no ano de 2009, ele muda de Campus com a finalidade de concluir o curso de Informática, na modalidade do Proeja.

Quando Rafael chega ao Campus Serra, sua vinda já era esperada há dois anos, isso porque a informação do ingresso de três educandos surdos no curso de Informática chega para os professores e funcionários do Campus Serra, ainda em 
2007. Nesse campus os profissionais seriam os próximos a trabalhar com esses educandos e por isso, necessitavam conhecer um pouco mais as questões referentes a surdez.

Trazemos primeiramente o depoimento do professor Gabriel. Este profissional trabalhava em duas funções dentro do Campus Serra, quando Rafael ali estudou. Ele era professor e coordenador do curso de Informática. Indagado sobre como se deu os primeiros contatos com Rafael, o professor expõem de forma interessante, como a presença deste educando o instigou não só para repensar a sua metodologia de trabalho, como também a pesquisar este tema, o que culminou com sua dissertação de mestrado.

Na verdade tem dois momentos do contato com o aluno surdo na minha experiência. A primeira, foi antes mesmo de ele estar na sala, quando nós, em 2007, mais ou menos, soubemos que ele viria. Porque ele ficava em Vitória e depois de dois anos ele viria para a Serra. Eles entraram em Vitória, foram três. Então, nós ficamos um pouco assustados, porque como nós iríamos trabalhar com esses alunos, dado que nenhum de nós tínhamos experiência e até mesmo o lfes, em termos gerais, ele quase não atende pessoas com Necessidade Educativas Especiais - NEE, ou pessoas com deficiência, que seja, historicamente falando, apesar de lá ser o lugar deles também. Foi isso inclusive que motivou a minha pesquisa de mestrado, ai eu comecei a estudar, ler dissertações, comecei a ter contato com Skliar, Perlin e os autores da área e ali, de certa forma, quando ele chegou na minha sala de aula, ele já não era mais aquele estranho. Porque eu já havia tido o contato com alguma coisa que me falava sobre esse sujeito, não especificamente, aquele aluno, mas o surdo enquanto movimento.

Percebemos aqui que a antecipação da notícia da chegada de um educando surdo propiciou a este professor, em tempo hábil, para a busca de informações e leituras dentro da área da educação de surdos, o que de certa forma, o auxiliou a compreender mais sobre as diferenças deste educando. Ou seja, o professor assume o que Amorin (2007) aponta como o pensamento não-indiferente, já problematizado no primeiro capítulo deste trabalho. 
De certo modo, este professor transferiu para o seu trabalho uma preocupação ética e estética, que culminou com a busca das teorias da área da surdez, para a produção desse trabalho não-indiferente, assim, compreendemos que o trabalho feito por Gabriel em antecipar-se a chegada deste educando faz com que ele o dimensione numa perspectiva histórica e isso, fez toda a diferença na realização do seu trabalho, tanto como professor ou como coordenador do curso de Informática.

\begin{abstract}
Mesmo assim, houve um estranhamento, um temor, eu não sabia como lidar com aquela situação, a presença do aluno surdo é incomoda, partindo do pressuposto que eu não me sentia competente para lidar com aquilo. Mas enquanto eu era professor dele, eu também era coordenador do curso dele, então eu tinha que atuar em todos esses aspectos. Contratação de intérpretes foi a primeira coisa que nós fizemos, pensando nesse sentido de ajudá-lo, mas a própria instituição tem essas limitações, não existe esse cargo intérprete, o que existia era professor substituto, e era como a gente contratava. Eles só me deram um, então a princípio, isso foi um problema, porque quando a intérprete faltava, nós tínhamos que nos virar com ele. Ninguém conhecia a língua de sinais, nem eu nem os alunos, então era uma sensação de impotência, muitas vezes, diante disso.
\end{abstract}

É possível constatar na fala do professor a existência de um receio mediante a presença do estudante surdo em sala, mesmo tendo buscado leituras, se preparado para recebê-lo, a sensação de impotência, apontada por Gabriel traz insegurança sobre a sua prática. Isso devido às barreiras linguísticas, uma vez que o professor admite não saber língua de sinais.

Compreendemos o sentimento do professor, afinal, seria uma experiência nova e cheia de possibilidades. Não só pelas questões pedagógicas envolvidas, mas também pela convivência com uma nova língua que ate então era desconhecida naquele espaço.

Contudo, este foi um momento de mudança destacado pelo professor, pois o 
movimento ocasionado por Rafael faz com que todos saiam de seu lugar de conforto e busquem através das relações dialéticas cotidianas, possíveis respostas para essa "novidade" que chegou até o Campus Serra.

Na verdade, o Rafael foi um ponto de mudança dentro do Ifes, descontando-se as agrotécnicas, como eu disse, os Ifes não recebiam alunos com deficiência, exceto aquelas deficiências que, entre aspas, são mais fáceis de lidar dentro do imagético das pessoas, como por exemplo, com a deficiência física, porque é mais simples, a pessoa tem uma limitação de movimento, não de comunicação. E o surdo e o cego, tem uma limitação de comunicação. Então, o que houve dentro do Ifes Campus Serra foi um movimento muito forte com a presença do Rafael, as pessoas se mobilizaram. Eu acho que a conjunção de pessoas interessadas naquele momento, de pessoas oriundas da educação, e especificamente da linha de diversidade, como a nossa pedagoga Anita, fizeram com que nós lançássemos um olhar diferenciado, não vendo o Rafael como um problema, mas sim como uma grande oportunidade nossa, de desenvolver alguma coisa dentro do Ifes, foi então que nós criamos o Núcleo de Apoio a Pessoa com Necessidades Educacionais Especiais - NAPNEE, que hoje se chama Núcleo de Apoio a Pessoa com Necessidade Específica - NAPNE.

As transformações impulsionadas pela chegada de Rafael propiciaram ao instituto outras demandas da política de inclusão de educandos com deficiência. Contudo, não podemos deixar de lembrar que Rafael demandava um olhar diferenciado em relação a sua diferença linguística, afinal, o fato da escola se movimentar, gerar discussões e outras atitudes, não dava conta da questão linguística dele.

Isso sempre rondou a relação dos profissionais da educação da escola em relação a este educando, por isso, os professores, pedagoga e intérpretes continuaram a se movimentar.

A partir desse movimento, nós criamos uma cartilha, sobre a diversidade, sobre a inclusão. Essa cartilha não falava só sobre surdez, ela falava de todas as deficiências, explicava a acessibilidade. Essa foi uma produção nossa, lá dentro nesse sentido, de criar esse espaço. Hoje o NAPNE, é uma 
obrigatoriedade institucional para todos os Campi na Instituição. Todos os Campi tem que instituir um NAPNE dentro deles, obrigatoriamente. Ele nasceu como um embrião na Serra. E ai na época, nos éramos CEFET-ES e depois nós nos tornamos Ifes e quando nós nos tornamos Ifes, as Agrotécnicas de Itapina, Santa Teresa e Alegre tiveram a opção de tornaremse Ifes também e eles aceitaram. E eles já tinham NAPNE, então eles já tinham uma experiência para contribuir, nós da Serra estávamos engatinhando e eles vieram com essa bagagem, com esse conhecimento e agregaram muito. Hoje nós temos encontros de NAPNE's dentro do Ifes, reunimos todos os NAPNE's, fazemos minisseminários, num movimento de integração. Fazemos palestras dentro dos Campi, somos convidados. Então a produção a partir do Rafael mudou a história do Ifes no sentido da diversidade.

Como o professor Gabriel mencionou no início, essas movimentações propiciaram ao Ifes uma oportunidade de pensar sobre a inclusão de modo geral, uma vez que tradicionalmente, por ser uma escola de excelência, pessoas com deficiência não alcançavam aquele espaço, e hoje com as políticas de inclusão, os profissionais destas instituições se vêem em uma posição, onde pensar sobre abordagens metodológicas diferenciadas e adequações arquitetônicas, são palavras de ordem às instituições federais.

Como segundo ponto, destacamos a contratação da intérprete Cecília, como o professor Gabriel apontou no início, a princípio, só foi possível contratar um intérprete, o que de certa forma, limitava a acessibilidade de Rafael dentro do Campus, pois o intérprete estava disponível apenas no horário de aula. Então, se o estudante quisesse chegar mais cedo para ir a biblioteca, participar de um grupo de estudos, ele ficava desprovido do serviço de interpretação.

Cecília foi então a pioneira naquele espaço, em seu depoimento ela aponta muitas dificuldades encontradas durante a sua atuação dentro do Ifes, muitas inclusive devido a sua própria limitação enquanto uma profissional que estava iniciando na área, ou seja, o Ifes foi a sua primeira experiência como intérprete. Podemos perceber em sua fala, que ela está em um movimento de constituição da sua 
identidade profissional.

Intérprete, intérprete eu não sou não. Eu comecei em 2003, em São Gabriel da Palha, o curso básico de LIBRAS porque eu queria aprender e logo depois, eu comecei a interpretar música na Igreja. Mas, em 2004 eu vim para Vitória, fiquei um ano parada só fazendo cursos. Na Igreja tal tem um curso, eu ia, descobri a pós-graduação, eu fui. Mas, nunca cheguei a declarar que eu sou uma intérprete como profissão, isso não, mas sempre quis trabalhar com surdos. Intérprete mesmo, eu comecei foi no Ifes, em 2008, ali eu comecei a trabalhar. Porque quando me avisaram que ia ter inscrição, falaram: porque que você não tenta fazer? Fiz, mas eu achava que não ia conseguir, porque vai ter prova prática e eu não tenho essa habilidade de intérprete, que muitas vezes o surdo tá falando e interpretar a versão voz, então eu tive muita dificuldade no começo. Então, dizer que eu sou intérprete, não, eu não sou. Eu gosto de LIBRAS, eu gosto de trabalhar com o surdo.

A insegurança de Cecília em se intitular como intérprete tem ligação com dois fatos. Primeiro, por ela admitir que não tinha experiência, segundo, por não ter formação.

Cabe aqui ressaltar que as formações de intérpretes em nosso estado são muito recentes, as primeiras "formações de intérpretes" que existiram aqui foram de cunho religioso, isso até o ano de 2006, quando o Instituto Mãos que Falam - IMQF abriu a primeira turma de formação de tradutores intérpretes de língua de sinais, sendo seguido pelo curso de Letras/LIBRAS Bacharelado que data de 2008, o da Associação dos Profissionais Intérpretes e Guias-Intérpretes de LIBRAS do Espírito Santo - APILES de 2009 e o curso tecnólogo da SEDU que data de 2010. Assim, é compreensível que muitos profissionais que atuavam como intérpretes de LIBRAS nesta época fossem mais do movimento e da experiência, do que propriamente intérpretes com formação profissional.

Contudo, o que Cecília nos aponta é preocupante porque segundo Lacerda (2009)

Para ser intérprete é necessário amplo domínio de pelo menos duas línguas: a língua de origem e a língua alvo - LIBRAS e Português - , mas esse domínio não se refere apenas à fluência, refere-se fortemente a um 
conhecimento da polissemia da língua, da diversidade de sentidos e possibilidades, de temáticas e aspectos da cultura que perpassam cada uma das línguas, já que a tarefa de interpretar implica não apenas verter palavras/signos de uma língua para outra, mas verter sentidos/significados estruturados linguisticamente na língua alvo. (p.31)

Assim, a partir do que Cecília nos conta e Lacerda (2009) problematiza, percebemos que a falta de experiência com LIBRAS que a intérprete alega pode ter sido um dos motivos das dificuldades que ela aponta ter vivenciado em sua trajetória. É óbvio que com o tempo, e isso nós veremos presente na fala da intérprete, ela vai vencendo isso. Mas, que para outro momento isso deve ser repensado, afinal, ser intérprete era a função para a qual ela foi contratada e para isso a fluência linguística era necessária.

Nas fala a seguir, Cecília demonstra como foi se apropriando dos sinais e conduzindo sua experiência como intérprete dentro do lfes Campus Serra. Muito do que ela aprendeu foi proveniente da relação que ela constituiu junto com Rafael e também, na busca por uma auto formação.

O Rafael era um aluno que sabia LIBRAS, ele veio de São Paulo, ele já tinha uma caminhada de LIBRAS, ele sabia muito mais do que eu sabia de LIBRAS, então ele me ensinou muito, principalmente as expressões do curso técnico.

Às vezes eu sentava com o Rafael para estudar, buscava nos textos as expressões de forma mais simples para que ele entendesse e ele me ensinava os sinais, isso quando os professores mandavam o material, porque tinha aula que eu chegava e recebia o texto na hora, e eu falava: e ai Rafael? Ai ele respondia, vamos dar uma olhada aqui rapidinho. Porque ele entendia, então, ele me ensinou muita coisa. Outras coisas eu buscava em dicionários, na internet.

Essa fala de Cecília foi muito intrigante porque, num momento ela estava falando sobre como foi se desenvolvendo dentro de sua atuação, e repentinamente, ela tocou no assunto do trabalho colaborativo com os professores. Ficou evidente nesta parte que, de alguma forma, ela enxergava empecilhos nesta relação, que segundo 
Lacerda (2009) é de suma importância para o sucesso do processo educativo de surdos incluídos em salas regulares, o trabalho colaborativo entre professor e intérprete.

Na verdade, o trabalho colaborativo não existia se o intérprete não fosse atrás, eu to falando isso, pela minha experiência lá. Se eu não fosse atrás dos professores não tinha. Poucos que falavam que iam mandar por e-mail, ai mandavam cinco e meia da tarde e seis e meia começava a aula. Como que eu estudava isso? Ou então, te mandavam meia noite, ai você trabalha no outro dia. Então, como eu ia tirar dúvida com um professor que não atendia ao telefone? Tinham alguns professores que diziam: marca o horário. Ai, eu marcava, e sentávamos eu, ele e o Rafael.

Podemos perceber que, segundo a intérprete a relação entre ela e os professores era um pouco distante. Lacerda (2009) aponta que a tarefa do intérprete envolve tornar os conteúdos acessíveis para o aluno, ainda que implique solicitar ao professor que reformule sua aula, pois uma tradução correta do ponto de vista linguístico nem sempre é a melhor opção educacional para propiciar o conhecimento. (p.35)

Como a intérprete poderia sugerir tais mudanças, se o texto era passado em cima da hora, ou o professor não socializava a informação. Ou mesmo, como ela iria sanar as suas dúvidas se o professor não as esclarecia. Então, percebemos aqui que o trabalho colaborativo, com vistas à inclusão do Rafael, ficava prejudicado.

A pedagoga Anita relata que no começo foi um pouco difícil, mas que com o passar do tempo, foi surgindo uma preocupação por parte dos professores em pensar maneiras de incluir o Rafael.

O Rafael surgiu para desestabilizar as práticas que já eram cristalizadas, né. Então, os professores que ainda não tinham tido contato com ele, ficavam: ai ele vai ser meu aluno semestre que vem, como é que eu fazer? Ai, a gente sempre se reunia e fazia uma reunião dizendo das características. Gabriel era como se fosse uma espécie de professor 
referência, porque desenvolveu no primeiro módulo todo um trabalho com ele, voltado principalmente para a criação de sinais na área de lógica de programação, pro Rafael entender a matéria. Então, Gabriel foi o primeiro que se propôs: é possível fazer diferente.

Assim, como no Ifes de Vitória, foi preciso tempo para que os professores compreendessem as demandas do educando surdo e que, para dar certo, era fundamental a parceria com o intérprete de LIBRAS e o repensar das práticas cotidianas. O que vemos aqui é um movimento no qual a escola teve que se envolver, por mais que, no início, tenha havido resistência, ou falta de compromisso, como nos aponta Cecília, a tendência foi, a partir do envolvimento de todos, que outros caminhos pudessem ser estabelecidos.

O NAPNE foi um marco interessante, pois com a existência deste núcleo, que demanda organização e verbas próprias, foi possível articular outras medidas, que dimensionaram este educando para além de um participante das aulas. Rafael pode se beneficiar das políticas implantadas pelo NAPNE a partir de cursos LIBRAS, que Ihe propiciaram, além de uma bolsa, a possibilidade da circulação da sua língua dentro do Campus Serra. Sobre essa experiência, destacamos a fala de Anita.

Nós temos o NAPNE, e este núcleo começou a trabalhar em cima das necessidades de Rafael, vamos trabalhar juntos. Então, foram desenvolvidas muitas ações com esse núcleo pra Rafael. Uma delas, e que a gente sentiu necessidade logo no início, foi da criação de um curso de LIBRAS, pros colegas da sala de Rafael. Porque a turma acolheu o Rafael, mas sentia necessidade de comunicação, como que eles iam se comunicar com ele? Então, pelo NAPNE, nós conseguimos criar uma bolsa pra ele de monitoria, e ele era o monitor do curso. Então, na primeira turma eu e Cecília sentamos para fazer todos os materiais, a apostila e tudo. E o Rafael, só assinava a listinha de presença dele, que ele foi lá e deu o curso. Ai, na segunda turma, a gente colocou que o Rafael tinha que assumir a responsabilidade dele de monitor, ele tem que aprender, não e a gente que tem que fazer a apostila pra ele. Ele tem que participar desse processo. E eu colocava horário de reunião com ele e ele frequentava, eu perguntava a 
opinião dele sobre a apostila, e ele opinava ia e fazia. E na sala de aula, quem dava o curso era ele, Cecília ficava como apoio. Além da turma dele, frequentaram as aulas os professores, inclusive professores que nem davam aula pra ele $e$ funcionários. Ao todo, nós ofertamos umas quatro turmas.

Eu comecei a observar que ele ficava muito sozinho na escola. Eu pensava: gente, é muito angustiante, eu não ter ninguém pra conversar, porque só eu domino LIBRAS. Então, quando eu vi que o curso não funcionava, porque eram pessoas que sabiam LIBRAS, mas não eram surdas, eu sentei com Cecília e Pablo ${ }^{55}$, na época, e disse: eu tenho observado que nós precisamos trazer mais pessoas surdas para a escola, não apenas Rafael.

De fato, garantir a existência de cursos de LIBRAS em instituições que possuam educandos surdos matriculados é um dado interessante, contudo, seguindo o pressuposto da dialogia, esse curso gerou uma aproximação, mas não uma construção dialógica, pois a experiência dos outros alunos, é uma experiência ouvinte, ou seja, uma experiência linguística diferente, e por isso não consegue promover o exercício dialético de interiorização e exteriorização dos signos e consequentemente, dos sentidos, com o estudante surdo, de forma clara.

O curso de LIBRAS lança uma fagulha, mas para existir uma relação que promova este exercício que Bakhtin (2006) propõe, é necessário que os sujeitos falem a mesma língua, de forma fluente e contextualizada.

O que Anita problematiza é sinalizado por Thoma e Kraemer (2009a), quando as autoras nos dizem que

Os surdos, na maior parte das vezes, se encontram com outros surdos no espaço da escola e é nela que senso do pertencimento, de estar em comunidade, começa a ser articulado. Por isso, nosso interesse em olhar para esse espaço e para os sujeitos que nele habitam, tentando entender como as identidades de professores de surdos e dos próprios surdos vão se constituindo e como a diferença ai se produz. (p.260)

As autoras apontam que muitos surdos se constituem como membros da

55 Pablo é o segundo intérprete que foi contratado pelo Ifes, em breve falaremos dele. 
comunidade surda na escola. Assim, o que a pedagoga Anita expõe é justamente a ausência dessa comunidade e consequentemente a solidão de Rafael.

Para tentar amenizar esse distanciamento que existia entre 0 instituto e a comunidade surda, foi pensado um evento que traria os surdos para a escola, o Papeando em Sinais.

O que seria o Papeando em Sinais? Seria um grupo de surdos, na instituição Ifes para discutir questões do cotidiano e a surdez. Então a ideia era discutir família e surdez, discutir sexualidade e surdez, trabalho e surdez, e como que o Rafael ia se vendo nesse movimento. Então, no primeiro grupo, a gente tentou marcar apenas um grupo de pessoas surdas. Pra ele se sentir fazendo parte do grupo .E em seguida a gente foi abrindo pra outras pessoa turma e da escola que quisessem participar

Todo esse movimento foi pensado para trazer a comunidade surda para dentro do Ifes e consequentemente, beneficiar o Rafael pelo contato com outros surdos, uma vez que ele veio de São Paulo e conhecia poucos surdos aqui, e também, devido a sua limitação física, que o impedia muitas vezes de interagir socialmente devido às fortes dores que ele sentia.

A pedagoga Anita apresenta nesta parte de seu depoimento, uma preocupação voltada para os aspectos culturais da inclusão do Rafael naquele espaço, visto que, por mais que fossem feitas as adaptações para garantir a acessibilidade, elas não davam conta dos aspectos culturais que só a presença de outros surdos e a circulação da língua de sinais, poderia garantir. É o que Bakhtin (2006) diz quando afirma que o interlocutor não pode ultrapassar as fronteiras de uma classe e de um época bem definida. (p.115)

Deste modo, compreendemos que os outros surdos seriam os interlocutores que faltavam ao Rafael. Sabemos que a turma de Rafael o acolheu muito bem, que ele fez muitos amigos, contudo, nenhum deles vivia a mesma experiência surda de 
Rafael, não tinham o que Bakhtin (2006) denomina de a palavra como sendo o território comum do locutor e do interlocutor. (p.116). Anita nos conta que através do papeando, foi possível que ele encontrasse esse território comum.

E ai, o Rafael começou a perceber que era possível o surdo casar, porque ele viu, lá no papeando que uma surda era casada. E ele entendeu que ele poderia casar e ter filhos, né, ele falava isso, porque ele descobriu isso, que outras pessoas na condição dele, que estavam no mundo, igual a ele e mostrando pra ele que era possível e eu falava pra ele: Rafael, veja isso. Nos momentos em que ele queria desistir do curso, porque ele achava que era muito difícil.

Através da experiência com os seus pares, Rafael pôde compreender que existem outras realidades para os surdos, para além da escola.

Toda essa movimentação ocasionada pela presença de Rafael na escola trouxe muitos benefícios, não só para o educando em si, como também para os seus colegas. Sobre isso, o intérprete Pablo nos aponta que durante as explicações das aulas, ele procurava dialogar com os professores e solicitar que as explicações fossem melhor pensadas, através de desenhos, por exemplo.

O que eu, o coordenador e a pedagoga solicitamos aos professores: que tornassem as aulas mais visuais, porque a língua de sinais, é uma língua visual, então, o que muitas das vezes, vocês só falariam, passem imagens, figuras, fotografias, desenho, organograma, enfim, mais imagens para que isso possa facilitar a compreensão dele, porque ele tá vendo uma interpretação né, o tempo entre a sua fala e a interpretação já tem uma distância, porque o intérprete está em um processo tradutório né, então às vezes, você já terminou um assunto e o aluno ainda está pegando o que você já acabou de falar. Então, com imagens, isso vai facilitar. $E$ isso foi positivo, não só pro Rafael, porque todos os professores começaram a fazer isso, mas para a turma inteira, (e depois os professores começaram a perceber) que foram se beneficiando dessas mudanças, ou seja, foi uma facilitação de acesso, que foi bom não só pro aluno surdo, mas também para os alunos ouvintes. 
Muitas vezes o professor esquece que o educando da Educação de Jovens e Adultos que está ali, passando por esta formação, traz dificuldades inerentes a sua formação, ou mesmo, devido ao tempo em ficou distante da escola. Então, o fato de procurar outra estratégia para facilitar o aprendizado do educando surdo, beneficiou os demais, alcançando assim o objetivo do processo educativo, que é a compreensão e o aprendizado.

Um outro ponto que vale destacar dentro da fala de Pablo é a evolução na relação entre professor e intérprete que ocorreu dentro da escola. Nós vimos que no início, Cecília evidenciou que era uma relação um pouco difícil. Já Pablo, como ele vem depois, já aponta sinais de que essa relação havia tido ganhos positivos.

Pois, segundo Lacerda (2009) a responsabilidade de ensinar é do professor. (p.35). Deste modo, a forma como Pablo conseguiu articular as suas participações nas aulas deixou isso muito claro.

Nas minhas interpretações em sala de aula (alguns professores, claro que cada um tem o seu estilo), alguns professores falavam muito rápido e eles se preocupavam com isso, então, em dado momento da aula eles paravam e falavam: desculpa, eu to indo rápido demais, quer que eu volte? $A i$, essa pergunta que eles me faziam, eu jogava pro Rafael: Ele tá explicando muito rápido, você quer que ele explique outra vez? Ai, às vezes ele dizia que estava tudo certo e outras, ele pedia desculpa e pedia para repetir. Os professores começaram a aprender a ter essa preocupação: será que ele tá pegando bem, será que o intérprete está passando conforme eu estou explicando? E sempre quando terminava a aula, agora é atividade: fazer exercício da página tal, ou o exercício que eu mandei pra vocês por e-mail, os exercícios que vocês baixaram do site, a escola fornecia essas possibilidades. Ai, os alunos começavam a fazer as atividades e o professor vinha conversar comigo: e ai, você achou muito complicado, ele pegou bem? E eu dava o retorno, porque muitas vezes, durante a explicação, eu e o Rafael conversávamos, então eu dizia ao professor: hoje o Rafael comentou que lembra disso da aula passada, hoje ele comentou que viu isso no exercício tal, e o professor sempre tinha um feed back positivo. Mas, eu sempre jogava para 0 
professor, pra eu não ser a fonte de informação eu virava e perguntava: Você quer perguntar pro Rafael? Então, eu sempre direcionava o professor pro aluno, pra ele ter essa liberdade, pra eu não ser o único vínculo com o aluno, pra ele ir sem medo. $E$ isso dava confiança ao professor, pra ele ir se apropriando desse aluno surdo.

Podemos perceber aqui uma relação potencializada por esse novo olhar, Lacerda (2009) aponta que a presença de um intérprete educacional em sala, a realidade, embora continue com barreiras, sofre alterações podendo trazer benefícios ao aluno surdo. (p.36). Ou seja, o professor continuava a não saber LIBRAS, contudo, este era o tempo todo provocado pelo intérprete a reconhecer o surdo como seu educando.

Alguns professores se interessavam por língua de sinais, uns
queriam aprender, queriam saber como era o sinal disso, o
sinal daquilo, ou então, durante a explicação da aula, ele
perguntava: eu quero ver que sinal você vai utilizar pra falar
isso, ai eles colocavam um slide no quadro, mostravam um
desenho, eu traduzia, e eles perguntavam: e ai, explicou,
entendeu? E eu respondia que o Rafael tinha entendido. Então
a aula ganhou uma dinâmica com a minha presença.

E o que foi positivo para os outros alunos também, teve uma vez que duas das aulas que eles faziam, o Rafael não fazia, porque ele tinha ficado reprovado, então nem ele e nem eu íamos àquela disciplina, no dia seguinte eu encontrava os alunos e eles diziam: poxa por que que vocês não estavam na aula de ontem? Ai eu respondia, porque o Rafael não faz essa disciplina, e os alunos diziam: a que pena, porque eu compreendo melhor quando vocês estão na sala de aula. Ou seja, eu passei a ser, aquilo que o professor fala, materializado. Eles viam em mim o que o professor estava explicando, porque quando você vai explicar no ar, o professor vai explicando o esquema que está lá estático no quadro e eu pego aquilo e dou movimento, porque esse aqui manda para todos os outros, esse aqui, ter uma coisa central que distribui, o fato de fazer isso em sinais, clareava o entendimento dos alunos.

A presença do intérprete Pablo foi uma grande motivação para os professores e educandos ouvintes, pois através de sua atuação, as relações sociais ali imbricadas, resultaram no que Bakhtin (2006) diz sobre a importância dessas relações e de 
como elas interferem de modo "onde a situação social mais imediata e o meio social mais amplo determinam completamente e, por assim dizer, a partir de seu próprio interior, a estrutura da enunciação". (p.113)

Ou seja, o imediatismo do aprendizado existente naquele espaço escolar passou a estar imbricado ao desempenho do intérprete em sala, pois, quando ele estava presente, o professor pensava em estratégias diferenciadas e todos os educandos se beneficiam disso, compreendendo o que era enunciado pelo professor.

De qualquer forma, a situação social determinava como as coisas iriam fluir naquele espaço, e essa determinação ficou marcada pela presença do intérprete e do educando surdo.

Mas, o fato era que todos os educandos tinham dificuldades e que a metodologia dos professores deveria ser observada a fim de tentar responder as demandas das turmas do Proeja. Afinal, esses educandos vinham de um processo histórico de exclusão e demandavam outras atenções. O intérprete Pablo percebia essa dificuldade por parte de todos os educandos.

Na sala de aula você vê, isso não era comum só ao Rafael, por exemplo, muitos alunos que chegavam para fazer esse curso técnico no Ifes, eles vinham de um ensino médio, ensino fundamental já com dificuldades e ai que você vê que não é um problema só do aluno surdo, é uma coisa geral. O aluno sai do ensino médio, vai para o ensino profissionalizante, vai para uma faculdade, com um grande dificuldade de leitura, de compreensão de um texto que ele lê, uma grande dificuldade de se expressar na escrita e de se explicar oralmente.

O Rafael tinha mais facilidade em se explicar oralmente (em sinais), do que pela escrita, mas diferentes de outros surdos que tem muita dificuldade, ele tinha uma dificuldade moderada, ele tinha um bom domínio. Inclusive, quando ele estava escrevendo, ele perguntava pra mim: aqui entra NO ou NA, ou seja, ele já sentia falta de uma conjunção, de uma preposição, de um artigo, ele não sabia se era masculino ou feminino, mas 
ele percebia essa falta. Eu sei que precisa, mas não sei qual é.

As dificuldades aqui apresentadas são comumente verificadas quando tratamos de educandos surdos e educandos provenientes da EJA de modo geral, surdos ou ouvintes, isso porque essa é uma marca de sua trajetória escolar, que por motivos diversos: comunicação, questões sociais ou de aprendizado, foram fazendo com que esses estudantes, ao longo de seu percurso, ficassem prejudicados nos aspectos concernentes à leitura e a escrita.

O que o intérprete aponta como sendo uma dificuldade geral, nos mostra a realidade dos estudantes do curso de Informática do Proeja no Campus Serra. Entretanto, se o simples fato de estudantes ouvintes, que não sabem LIBRAS, acompanharem a tradução do intérprete, conseguirem compreender melhor o conteúdo, nos faz pensar, o que estes professores, falantes da mesma língua desses estudantes ouvintes, que é o Português, poderiam fazer por seus educandos?

O que Pablo nos aponta é uma reflexão muito forte, pois se os ouvintes estavam em uma condição de acesso a língua mais privilegiada, então porque recorrer a uma língua que eles não dominam para compreender um conteúdo? Eis uma questão que nos faz pensar sobre a metodologia dos professores e sobre uma fala do professor Gabriel.

Até pouco tempo atrás, quando nós tínhamos a EJA, os alunos da EJA eles eram como bolhas dentro do lfes, eles eram grupos que estavam dentro, mas que não faziam parte, na visão geral. Tanto que houve um período em que os alunos do regular entraram em férias antes dos alunos do Proeja, porque - EJA teve que atrasar a entrada e tal, por algumas questões legais ali. Então, neste período de interstício, entre as férias dos alunos do regular e a permanência dos alunos da EJA, os alunos da EJA estavam sozinhos na escola e eles chegaram a comentar isso: Agora eu sinto essa escola como minha, me sinto parte desta escola. Porque quando os outros alunos do regular estavam, eles não se sentiam, eles se sentiam estranhos dentro da instituição. Então os alunos, mesmo matriculados, regulares até de curso, eles não se sentiam 
como parte. Porque até pelo fato do Ifes ser uma instituição de excelência e atender, ate então, alunos de excelência, era uma disputa muito acirrada para entrar ali, disputas de vagas ali, pau a pau, nós tínhamos a nata dos alunos da Grande Vitória, até mesmo porque eram filtrados nesse processo. Então, os professores se acostumaram a esse perfil de aluno, um aluno que vem de uma concorrência de 9 por 1 vaga, de 8 por uma vaga. Hoje a concorrência do Ifes caiu muito, nós temos cursos que muitas vezes não preenche o número de vagas, a concorrência é menos de 1 por vaga. Então, mesmo nos cursos regulares, o nível de excelência desse aluno caiu. Então, quando esse aluno da EJA chega na instituição, ele já é visto como fruto de fracasso, porque é a pessoa que não concluiu no tempo regular, e os professores não estão nem preocupados e a comunidade também não está preocupada em saber o porque. Às vezes, ele precisou trabalhar, ou ele adoeceu, ou ele ficou internado, ou esse aluno viajou, quais os motivos que o levou a não concluir naquele tempo. Ele já é um perdedor, ele já é um fracassado, quando ele entra com esse rótulo do Proeja. Teve alunos, do curso técnico de Serra (o professor tinha duas pautas: a do técnico pós-médio e a do Proeja), houve um semestre em que ocorreu um erro dentro do sistema acadêmico, ai alguns alunos que eram do técnico pósmédio, foram registrados como alunos do Proeja, ele vieram me questionar, eu era o coordenador: eu não quero o rótulo de EJA no meu currículo, eu não quero que no meu currículo apareça um rótulo de EJA, eu não sou da EJA. "Então, esses lugares e não lugares, eles estão na cabeça das pessoas".

Percebemos na fala do professor uma concepção existente sobre quem era o aluno do Proeja, quais assinaturas esses alunos traziam consigo. Mesmo que fossem bons, dedicados, com frequência regular, como aponta o professor em sua fala, isso não era o bastante para que os professores, muitas vezes, repensassem sobre suas práticas, porque não queriam sair de seu lugar de conforto que estavam acostumados a ter.

Contudo, como problematizamos no início deste trabalho, a legislação prevê educação para todos, então, o fato de a concorrência de vagas estar desaparecendo, não significa a queda na qualidade dos educandos que chegam, mas sim a abertura de vagas, a ampliação da rede federal. Então, se antes os 
alunos eram filtrados pelos exames e a quantidade limitada de vagas, hoje eles chegam, com suas dificuldades, é porque o acesso tem sido mais democratizado, em cumprimento à legislação.

Cabe ao professor fazer esta reflexão e compreender que agora, a sua sala de aula, é um espaço democrático e que não basta apenas o educando ter o acesso, ele precisa também de condições de permanência, caso contrário, vamos continuar a reproduzir a "peneira" dos processos seletivos, só que agora de dentro.

O educando traz as suas dificuldades e estas precisam ser problematizadas pelo professor com o intuito de atender ao anseio pelo aprendizado. Pois, se os educandos conseguiam compreender melhor, através de uma língua que eles não conheciam, então porque o professor não transforma o seu vocabulário e sua metodologia mais acessível a esses estudantes?

\section{A partida de Rafael e suas marcas deixadas no Ifes - Campus Serra}

No segundo semestre de 2009 ele fez o módulo 1, no primeiro semestre de 2010, ele fez o 1 de novo, então ele viu aquelas mesmas disciplinas novamente, porém com o grupo da tarde. Esse grupo da tarde foi muito especial pra ele. Não que ele não se desse bem com o pessoal da noite, mas o grupo da tarde eram pessoas mais jovens, e o pessoal da noite como chegava de uma rotina de trabalho, não tinham muito desprendimento de ficar com ele, de bater papo com ele. Estavam cansados, a matéria era difícil, eu até compreendo. E nisso, ele se sentia muito sozinho. O grupo da tarde, por ser mais adolescente, um pessoal de 18, 19 anos e ele tinha na época 25 anos, não estavam muito distante, o pessoal da noite era mais velho, tinham entre 25 a 30 anos e esse pessoal da tarde era mais entre 20 a 25 anos, ou seja, eram mais próximos a ele. E não era um pessoal que trabalhava o dia todo e chegava cansado. Era um pessoal cheio de energia, brincavam mais e eles se interagiam mais. De forma que, se a noite se destacavam 2 ou 3 alunos que se comunicavam bem, arriscavam uns sinais para se comunicar com o Rafael, a tarde era a turma inteira.

Ele passou a se interessar mais pelo estudo porque ele tinha 
um grupo de pessoas que trocavam mais com ele. Ele fez amizades fortes ali, foi nesse semestre inclusive que ele conseguiu tirar carteira de motorista e ele passou a dar carona para os colegas, ele morava em Vila Velha e dava carona pros colegas que moravam lá, ou até Ufes. Então eu percebi, como que uma pessoa que está numa instituição, precisa ter a companhia dos amigos, pois não basta só eu de intérprete, porque ele vai conversar só comigo? Né, porque ainda que eu estivesse ali facilitando o acesso ao estudo, à informação, eu não era suficiente. Nós somos seres sociais, então você precisa de um grupo, você precisa de outros, até pra se compreender melhor. E ele se deu bem com essa turma, porque eles estudavam com ele, chamavam ele pra outros programas, churrascos, passeios e tal.(Intérprete Pablo)

Nesse trecho apontado pelo intérprete Pablo, começamos a perceber que a inclusão do educando Rafael estava caminhando para melhores expectativas, visto que ele foi conquistando muitos ganhos dentro da instituição.

O incentivo para os estudos impulsionados pela contratação de outro intérprete, o que oportunizava a ida dele à escola em outros horários, o Papeando em Sinais, que eventualmente trazia os surdos para o Ifes, a melhora no trabalho colaborativo entre professores e intérpretes, a turma nova que o acolheu e a carteira de motorista, que a viabilizou ainda mais acessibilidade dele, tendo em vista a sua dificuldade de locomoção, foram questões importantes nesse processo de inclusão.

Contudo, ainda faltava uma coisa, para Rafael: o fato de repetir várias vezes a mesma disciplina, tinha relação com a sua dificuldade em expressar no papel o seu entendimento dos conteúdos. Isso devido a peculiaridade de sua escrita.

O intérprete Pablo, em sua fala, evidencia que os professores sabiam dessa especificidade e que estavam procurando avaliá-lo, levando em conta essa diferença.

Quando por exemplo ele recebia um prova e vinha uma nota ruim, por exemplo, o que já tinha acontecido, eu a pedagoga e 
o coordenador, já tínhamos falado com os professores que a escrita dele era diferente e que a escrita dele deve ser corrigida pelo conteúdo, pelo sentido, pela semântica e não pela gramática, porque na gramática, na verdade, aquele aluno esta fazendo uma tradução, e a gente não esta avaliando o que ele sabe passar de sinais para o português, mas como ele domina o conteúdo que é a informática. Então, os professores estavam conscientes disso. Quando eles tinham dificuldades de compreensão do texto dele, eles me chamavam: Pablo, isso aqui eu não entendi, vamos corrigir junto comigo. Então, eu sentava com o professor e corrigia prova com o professor.

Professor, deixa eu ler isso aqui primeiro. Então eu lia o texto ou o parágrafo e já visualizava quais sinais ele estava utilizando. Ai eu explicava: professor, quando ele fala isso aqui, por exemplo, a palavra trabalhar, não é o trabalho, em que que você trabalha, mas é no sentido de funcionamento é a ação desse sistema que ele está explicando. Ai o professor entendia. Eu ia realizando esse trabalho junto com o professor. Mas, ainda assim, ele não se conformava. E eu explicava Rafael, a sua nota não foi pelo jeito que você escreveu, mas foi pelo que você deixou de colocar no papel, e ai, ele ficava chateado.

Apesar da tristeza de Rafael evidenciada na fala de Pablo, podemos identificar através deste relato, que os professores estavam resignificando a sua forma de avaliar o educando Rafael.

Thoma (2009) aponta que as avaliações têm sido utilizadas como forma de ver este educando surdo dentro da escola. Então, o fato dos professores se predisporem a ter um olhar diferenciado sobre essa avaliação, nos dá algumas pistas de possíveis mudanças metodológicas, também na avaliação.

Pois, se segundo Thoma a diferença surda deve ser vista como uma condição irredutível, mas ela não pode ser negada. É como o intérprete Pablo sinalizou , "a gente não está avaliando o que ele sabe passar de sinais para o português, mas como ele domina o conteúdo que é a informática”.

Então, esses aspectos passaram a ser observados na hora de avaliar esse 
educando. Sobre esses novos aspectos, Pablo, traz um relato muito impressionante de uma reunião.

Por perceber que ele estava fazendo, cada módulo duas vezes, duas vezes o módulo 1, duas vezes o módulo 2, a escola percebeu que ele não estava avançando. Muito pelo contrário, como é que a gente pode fazer para que ele possa acompanhar, com os colegas que ele esta estudando, pra ele não ficar sempre repetindo. A gente tinha feito uma reunião na quinta ou na sexta-feira, antes da morte dele, com os professores, o coordenador do curso, a pedagoga, a mãe dele e eu, como intérprete, sobre o que a escola poderia fazer para que ele tivesse um desempenho melhor, já que existem tantos fatores, o fator locomoção já estava resolvido, por conta da carteira, ele já tinha possibilidade de dirigir até a escola. E ficou decido o seguinte: eu dei o exemplo do que nós fazíamos aqui na UFES, no curso de Letras/LIBRAS, que a prova para os alunos surdos era feita em língua de sinais, então para ele já era um grande avanço ai, se não fosse possível fazer as perguntas em língua de sinais, que fosse possível ele responder em sinais. Por que o que ia mudar ai? Apenas a forma de você registrar a resposta e mudar o suporte. Nós íamos mudar do suporte papel para o suporte CD ou DVD. As respostas dele seriam gravadas por uma câmera e sendo uma escola de tecnologia, um instituto tecnológico, isso é coisa que não falta. Então, ele gravaria as respostas em sinais, o que daria mais segurança pra ele. E na hora da correção, eu estaria junto com o professor, dizendo o que ele estava dizendo, poderíamos voltar o vídeo quantas vezes fossem necessárias para ter certeza. Nós só mudaríamos o suporte. Então foi aceito. Eu acho que essa reunião foi numa sextafeira, porque teria o fim de semana, passaria a segunda, que ele não tinha aula e na terça-feira ele receberia a notícia.

Passou o sábado, passou o domingo, passou a segunda-feria. $E$, na segunda-feira ele marcou de ir com os amigos ao cinema, né, de carro, ele pegou todo mundo em casa, ou se encontraram no shopping, eu não sei, e terminou o filme era cerca de meia noite e pouco, ele deixou todos eles em casa, eram quatro se eu não me engano, deixou cada um em casa. Depois de deixar a última pessoa em casa, ele foi pra casa e nesse percurso, a 500 metros da casa dele, ele bateu com o carro e veio a falecer. Ele não faleceu ali na hora, mas foi uma batida muito violenta, o carro ficou bem destruído, perda total né. Chegou ainda a ser socorrido, mas não resistiu. 
Infelizmente, as propostas avaliativas que a escola estava disposta a acolher não puderam ser efetivadas para o estudante Rafael. Para ele, elas chegaram tarde demais. Contudo, a convivência com este educando fez com que os professores repensassem as suas práticas, que segundo a pedagoga Anita, eram práticas cristalizadas. E mesmo que elas não tenham alcançado o educando Rafael, a partir dessa nova proposta discutida em reunião pedagógica, é muito importante que elas possam ser pensadas para todo e qualquer educando que necessite deste outro olhar.

Porque é o que Thoma (2009) nos diz como uma prática cultural, a avaliação esta presente em nossas relações desde que nascemos. Cotidianamente, somos interpelados por discursos que avaliam (p.52). Então, se somos o tempo todo avaliados, a avaliação precisa ser o tempo todo problematizada.

Um dado muito angustiante presente na fala do intérprete Pablo é quando ele nos toca com o seguinte depoimento

\begin{abstract}
"Pra mim foi muito chocante porque, na tarde em que eu iria interpretar uma aula pra ele, em que a gente ia dar as novidades pra ele, do que a escola ia fazer, adaptando-se ainda mais as necessidades dele, pra ele poder estudar, se adequando ainda mais a isso, eu fui interpretar o velório dele, então, isso pra mim foi muito pesado. E depois, que no dia seguinte de manhã, eu fui interpretar o enterro dele né. Então, foi uma experiência que eu tive como intérprete, que eu não tenho nem como medir."
\end{abstract}

Essa fala nos faz pensar sobre este intérprete, que também é feito de carne, que ele não é como uma rampa, ou uma bengala. Sabemos que todos os instrumentos, sejam eles materiais pedagógicos, recursos ópticos, adequações arquitetônicas, todos foram construídos em prol da inclusão, mas que o material humano, utilizado neste processo é o mais importante.

O sentimento exposto por este intérprete, o fato de sua ansiedade em dar a boa 
notícia, ter sido silenciada pela morte do educando o qual ele acompanhava, nos faz dimensionar o quanto é importante investir neste profissional que está ali, como um veiculo de acessibilidade. Expomos isso, baseados nesse sentimento, pois se o intérprete, viu-se em uma circunstância humana, de pesar, de perda, é porque ele foi envolvido pelo movimento, e porque ele estava ali para legitimar o que ele acreditava.

Ele mesmo nos disse em seu depoimento: "Nós somos seres sociais, então você precisa de um grupo, você precisa de outros, até pra se compreender melhor".

Após o falecimento do educando Rafael, o intérprete Pablo continuou no lfes Serra para dar continuidade ao trabalho que o Rafael fazia no NAPNE.

Em setembro, estava completando exatamente um ano do meu
contrato, que acabou sendo renovado, porque o Ifes, por conta
do NAPNE, tinha projetos, o Papeando em Sinais, era um
desses projetos, o Rafael sendo professor, sendo responsável
por ensinar LIBRAS aos interessados do Ifes, ele tinha uma
turma, e ai, o que aconteceria com essa turma. Então, esses
projetos tinham que ter andamento. Um dos trabalhos que nós
fizemos, foi registrar os sinais ali, criados pelo Rafael, os sinais
específicos da área de Informática, para que outros surdos que
possam estudar ali, possam utilizá-los. Era uma forma de
mostrar o resultado do acesso que a escola deu a este aluno e
o que isso trouxe de benefício pra comunidade surda, então,
esse era um trabalho que não podia morrer junto com o aluno,
precisava ser registrado.

É muito interessante o que Pablo nos aponta em seu relato, sobre a importância de registrar tudo o que foi feito para a inclusão do aluno Rafael no Ifes Campus Serra, pois outros surdos poderão estudar ali um dia e muitos dos esforços empenhados pela equipe pedagógica, já se encontram sistematizados.

Outro ponto interessante é que sempre houve uma preocupação por parte da equipe em entender que o Rafael, precisava de outros surdos ali com ele e de que a circulação da língua de sinais, ou da língua, de modo geral, como nos diz Bakhtin 
(2006), é um ponto crucial para que nós possamos interiorizar os conceitos e exteriorizar os significados e trazer os surdos para os momentos do Papeando em Sinais, foi algo muito importante.

Talvez, eles nunca tenham imaginado que muitos daqueles surdos, nunca haviam pisado em uma instituição federal, ou mesmo sabiam que eles poderiam tentar as provas de seleção. Muitos surdos deixam de ocupar os espaços, pela falta de conhecimento ocasionada pelas barreiras linguísticas, ou mesmo porque, são provenientes das classes mais humildes e sua família não possui esclarecimentos sobre as possibilidades que os surdos podem galgar.

Acreditamos que não poderíamos deixar de fechar este capítulo com uma fala que foi presente nos depoimentos do professor e coordenador Gabriel, da intérprete Cecília, da pedagoga Anita e do intérprete Pablo, que hoje o Núcleo de Apoio a Pessoa com Necessidades Específicas, o NAPNE, do Ifes - Campus Serra, leva o nome do educando Rafael. 


\section{CAPÍTULO V - PROJETOS DE VIDA A PARTIR DO RETORNO À ESCOLA - A EJA COMO POSSIBILIDADE}

A trajetória dos surdos no Ifes nos mostra uma experiência das possibilidades de práticas inclusivas que aquele momento histórico propiciou ao Instituto Federal, a seus professores, funcionários e educandos.

Sabemos que aquelas situações, problemas e transformações ali vivenciados contribuíram de forma significativa para a melhoria do atendimento as necessidades de cada estudante, não apenas dos surdos, uma vez que levantada a questão da inclusão, percebemos que muitos tencionamentos foram trazidos à tona.

Compreendemos que as reflexões motivadas por tencionamentos são extremamente enriquecedoras para a formação dos docentes e para as adequações à legislação vigente, uma vez que essas provocam mudanças que são necessárias a todas as escolas dos país e não apenas àquelas que possuem algum estudante com NEE.

Assim, construir espaços e escolas que possam atender as demandas dos estudantes torna-se atualmente o maior desafio das políticas de inclusão. Isso porque esses educandos querem alcançar o que a própria legislação Ihes garante "os mais altos níveis de ensino" e para tanto é necessário que as diferenças dos surdos sejam também consideradas nos espaços da EPT e do Ensino Superior.

Através do exercício do pensar historicamente que fizemos no capítulo dois deste trabalho, podemos compreender o porquê dos números elevados de reprovações nos casos dos estudantes surdos. $O$ fracasso escolar ao qual estiveram fadados por anos, devido às metodologias de ensino e as políticas vigentes ao longo da história, que resultaram em uma educação para surdos incipiente e com resultados questionáveis.

Uma forma de inclusão no espaço da escola que os estudantes surdos podem fazer, 
estando uma vez em defasagem escolar, é ocupar o espaço da EJA para que assim, retomando seus estudos, eles possam dar continuidade aos seus estudos e projetos de vida.

Sabemos que o espaço da EJA não objetiva a correção de fluxo, entretanto, não podemos deixar de observar que muitos surdos, estando matriculados nas escolas regulares, passaram por processos de exclusão que resultaram em sucessivas reprovações e consequentemente, o fracasso escolar. Deste modo, o espaço da EJA pode possibilitar a esses estudantes sua inclusão na escola, pois neste sentido, os movimentos da EJA têm trabalhado em prol de seguimentos socialmente excluídos por diversos motivos, inclusive, por não terem suas diferenças atendidas.

Uma iniciativa que trazemos para exemplificar uma possibilidade de trabalho a ser desenvolvido com esses sujeitos, a título de concluir este trabalho, é a EJA da Garoto. Traremos esse exemplo, para pensar algumas questões.

A EJA da Garoto é uma iniciativa da fábrica de chocolates Garoto situada em Vila Velha, no estado do Espírito Santo. Na perspectiva dessa empresa, os funcionários que ainda não possuem o ensino fundamental e o médio, devem ser atendidos por essa iniciativa a fim de que esses possam fazê-lo.

Como esta fábrica possui um grande número de funcionários surdos, foram destinadas duas turmas específicas para os alunos surdos. Nessas turmas, todos os professores são informados sobre as especificidades dos surdos através de uma assessoria pedagógica e o acompanhamento da intérprete da fábrica.

Uma indagação que talvez possa surgir é: Por que trazer este exemplo neste trabalho?

O nosso objetivo ao conhecer este espaço e dialogar com as pessoas que ali participam é de em primeiro lugar, conhecer a realidade dos surdos que retornam 
aos bancos escolares após todo o processo histórico que já pontuamos. Em segundo lugar, porque devido a morte de nossos sujeitos da pesquisa, ao longo da mesma, sentimos necessidade de ouvir mais surdos, sobre os seus projetos de cursar o ensino técnico profissionalizante, e por último, de conhecer um espaço que também precisa ser repensado a cada dia para oferecer aos surdos um ensino de qualidade e acessível para os mesmos, através de aulas traduzidas para a língua de sinais e materiais visuais. Assim, em nosso percurso, conhecemos a EJA da Garoto, seu cotidiano de trabalho e seus estudantes surdos.

As aulas acontecem nas dependências da Faculdade Estácio de Sá, onde os professores dispõem de equipamentos para trabalhar com materiais visuais, a fim de responder a esta demanda dos estudantes. Os professores trabalham em conjunto com intérpretes contratados de uma empresa de assessoria em interpretação e tradução - a Caesar LIBRAS. Como todos os alunos são adultos e possuem fluência em LIBRAS, a presença do intérprete torna-se significativa neste espaço, pois o mesmo, em parceria com o professor, consegue desenvolver seu trabalho de viabilizar o acesso aos conteúdos para os estudantes.

Nos dias em que ali estivemos, foi possível constatar que muitas das dificuldades sinalizadas pelos intérpretes que vivenciaram a rotina do Ifes, também se fazem presentes naquele espaço, contudo, o fato de todos os alunos serem surdos, facilita a troca entre os alunos, o que potencializa o processo educativo. Foi possível verificar, inúmeras vezes, momentos nos quais os estudantes sentavam em conjunto e discutiam a matéria, ou mesmo, no trabalho de troca, um ensinava ao outro.

É importante destacar esta parceria entre eles, porque durante muitos momentos em que ouvimos os narradores que trazem o processo dos estudantes surdos dentre do Ifes, o fator solidão, foi muitas vezes mencionado. E ali, na EJA da Garoto, percebemos que isso não acontece, pois todos que estão ali passam pela mesma experiência surda de mundo. 
Como este trabalho dedicou-se a "ouvir" narradores que vivenciaram as práticas educativas com estudantes surdos no cotidiano da escola, neste espaço, também não poderíamos ter feito diferente. Assim, nas quatro semanas em que nos envolvemos naquele espaço, foi possível conversar com professores, intérpretes e educandos sobre o que eles vivem e a partir de suas falas, chegar a alguns pontos interessantes sobre este processo de formação.

Foi realizado um momento de conversa com os estudantes, onde o objetivo era saber porque eles estavam ali, uma vez que eles não se encontram fora do que chamam de "mercado de trabalho". Nesta conversa com o grupo, foi possível verificar dois objetivos comuns entre os educandos: concluir os estudos por conta da exigência da empresa e concluir os estudos para dar prosseguimento em outros níveis ${ }^{56}$.

O objetivo dessa conversa com estes educandos, para essa pesquisa, não é desenvolver uma outra pesquisa diferente, mas constatar que, os surdos adultos que estão retornando à escola, estão retomando esta caminhada, devido as exigências atuais e também por conta de seus projetos pessoais de vida. Assim, compreendemos que não só na EJA da Garoto, como em outros espaços em que eles estejam essas necessidades emergem.

Por isso, ao percebemos que aquele espaço também era um espaço de diálogo com os surdos e que esses estudantes podem ocupar lugares como o ensino tecnológico e o superior, que resolvemos trazer as suas histórias como conclusão de nossa pesquisa.

Nos dedicaremos a apresentar as falas que evidenciam as duas preocupações assinaladas: a conclusão dos estudos e o prosseguimento deste em outros níveis. Para começar, traremos os depoimentos dos estudantes que entraram na EJA da Garoto com o objetivo de concluir os estudos.

56 Tecnológico e Superior. 
A primeira fala é a do estudante Celso. Ele destaca que na sua história de vida, passou pelo INES, onde aprendeu a língua de sinais, contudo, ele muda para o Espírito Santo aos 13 anos de idade, e a escola de surdos que existia aqui, era uma escola onde a metodologia era oralista. Segundo o estudante, ele passou por muitas dificuldades, o que o fez desistir da escola. Os anos se passaram e ele começou a trabalhar na Garoto, dentro da empresa, surgiu a necessidade de conclusão do ensino médio.

Eu comecei a trabalhar na Garoto. Eu gosto de trabalhar aqui. Então, a empresa começou a cobrar que seus funcionários terminassem o ensino médio. A empresa organizou uma turma e como eu queria voltar a estudar eu resolvi entrar. Lá me explicaram que eu teria um professor e um intérprete. Assim, eu aceitei e voltei a estudar. Comecei a estudar. Estudar é muito bom, porque nos dá oportunidade de mudanças, passamos a conhecer coisas novas, tecnologias, ou seja, vamos nos desenvolvendo. Agora, no futuro eu quero continuar a estudar, mas só se tiver intérpretes, se não tiver eu não vou, porque eu não vou aprender nada e não vai adiantar em nada para mim.

Pelo depoimento de Celso é possível verificar que o seu retorno à escola se dá pelo motivo da exigência da empresa, mas também porque naquele espaço, Ihe foi garantido a presença do intérprete de LIBRAS. Deste modo, fica claro que este estudante, é motivado a estudar pelos fatores que tornam aquele espaço positivo para a sua diferença linguística.

Percebemos aqui a importância que Celso atribui ao ambiente linguístico favorável ao seu processo educativo. É o que Bakhtin (2006) nos diz quando ele afirma que a língua é uma necessidade enunciativa (p.93), ou seja, a forma que esta adquiri num dado contexto, que no caso de Celso, sendo ele um surdo, isso é motivado pela língua de sinais.

Uma outra fala que nos chama muito a atenção é que muitos surdos naquele espaço possuem vergonha de estar ali e de suas dificuldades com os estudos. Em vários 
momentos, muitos deles destacaram esse sentimento, pois o fato de já serem adultos e não terem concluído o ensino médio, traz um peso muito grande para eles. Para exemplificar este sentimento, destacamos a fala de Laura

Já tem 8 anos que estou aqui trabalhando direto. Há um tempo atrás, a intérprete da empresa me apresentou o projeto EJA da Garoto, uma oportunidade para voltar a estudar. Ela me explicou que teríamos professores e intérpretes, eu gostei da novidade, mas no começo tive vergonha. Agora, que eu estou com 38 anos, a intérprete voltou a entrar em contato comigo, me explicou que eu deveria voltar a estudar, para evitar uma possível demissão, mas eu não queria. Cheguei em casa e expliquei para minha família. Eles me incentivaram, disseram que eu deveria voltar a estudar. Assim, procurei a intérprete e disse que eu aceitava, ela ficou toda feliz, mas eu continuava com vergonha e achando que seria muito difícil. Mas, ela me acalmou dizendo para eu ir devagar, se tivesse alguma dúvida, perguntar ao professor, interagir com os outros alunos, ai eu entendi. Levei meus documentos, fiz minha inscrição e comecei a estudar. Agora que estou aqui, estou gostando, está sendo bom.

A partir da fala de Laura, é possível constatar que esse sentimento tem desestimulado a estudante durante o seu percurso escolar, entretanto, também podemos perceber que aos poucos ela vem vencendo este sentimento no cotidiano das aulas e no contato com os colegas de sala.

No documento do MEC - Trabalhando com Educação de Jovens e Adultos: alunos e alunas da EJA, esse sentimento de vergonha é sinalizado como o medo de errar que este educandos tem, por conta de já serem maduros e não dominarem os conteúdos escolares.

O que se sabe, ao certo, é que o fracasso escolar tece uma espécie de teia, onde o(a) aluno(a) se enreda e custa a sair. Na maioria dos casos, a teia torna-se tão emaranhada que não oferece saída e o desfecho dessa situação, tão comum na realidade brasileira, é o abandono da escola. Mais tarde, quando retornam aos bancos escolares, os jovens e adultos ficam extremamente suscetíveis a enredarem-se novamente, a vivenciarem outro fracasso escolar. (MEC/BRASIL, 2006, p.17) 
A marca do fracasso escolar tem acompanhado os surdos ao longo dos anos, tanto os históricos dos alunos do Proeja e os da EJA da Garoto aqui destacados, tem nos mostrado as dificuldades destes educandos devido a uma má formação na base das séries iniciais. Muitos surdos chegam ao ensino médio sem saber ler e escrever, o que nos indica a possibilidade da existência desse sentimento de incapacidade destacado como "vergonha" que Laura nos apresenta e que José, ex-estudante do Ifes, único vivo, que nos deu o seu relato, também destacou em seu depoimento.

Mas, mesmo com todas essas dificuldades, eles estão ai, desejosos por continuar os seus estudos, mesmo que seja para manter o seu trabalho. Afinal, como pessoas que possuem família, estes precisam trabalhar.

Para finalizar, gostaríamos de destacar os depoimentos dos surdos que possuem outras perspectivas de formação. Vamos iniciar pelo depoimento de Maria

Eu já concluí o Ensino Médio, mas no passado, como não havia intérpretes, eu aprendi muito pouco do que deveria ter aprendido, não conseguia entender quase nada. Por isso, hoje estou frequentando a sala de ensino semestral da empresa onde trabalho, cursando novamente o ensino médio, pois como lá tem intérpretes de Língua de Sinais, eu consigo entender tudo mais claro. Eu fui a primeira surda da fábrica a ser credenciada em uma empresa de segurança do trabalho, isso me deixou muito feliz e eu tenho esperança. No futuro, quero fazer o curso de segurança do trabalho

Maria é uma surda militante dos movimentos surdos, em seu depoimento, ela gesticula com muita garra, tentando demonstrar os seus sentimentos, e mais, procura apresentar os seus projetos de vida fundamentados na continuidade dos estudos.

Além de nos dizer sobre seus projetos futuros e evidenciar a conquista de seu credenciamento, Maria faz um resgate sobre a sua história profissional, em um momento crucial de sua vida, em que ela precisava trabalhar, mas, não sabia por 
onde iniciar sua procura, por falta de informação e por conhecer a dificuldade que os surdos enfrentam para conseguir uma vaga de emprego. A forma enfática que ela utiliza para afirmar que já possui o Ensino Médio, mas que para ela ainda falta aprender mais, é uma marca muito significativa em seu depoimento, aparecendo algumas vezes durante a conversa que tivemos.

Essa dificuldade é enfrentada por diversos surdos, qualificados ou não: onde trabalhar? Qual empresa contrata pessoas surdas? Afinal, todos os seres humanos necessitam, através do trabalho, adquirir seu sustento e de sua família. Sobre essa dificuldade Maria nos diz

Surgiu a vontade de trabalhar, mas onde trabalhar? Ai eu encontrei a intérprete de uma fábrica que me disse que estavam acontecendo seleções para contratos temporários. Eu me animei e consegui um contrato. Fiquei um tempo como contratada. Quando o contrato acabou, tive que sair do emprego. Entretanto, mas tarde, participei de um processo seletivo para uma vaga de efetiva e consegui. Assim minha vida seguiu, minha filha na escola e eu trabalhando, até que um dia me veio a mente a vontade de voltar a estudar. Mesmo sendo já adulta eu queria voltar a estudar. Depois de um tempo, a intérprete da fábrica me disse que iria abrir uma turma de EJA para os surdos que trabalhavam na fábrica. Eu conversei com ela que mesmo eu já sendo formada no ensino médio eu queria estudar mais. A intérprete pediu para que eu aguardasse enquanto a fábrica estava realizando os procedimentos de organização das turmas. Quando tudo ficou pronto eu corri e fiz minha matrícula. Assim eu voltei a estudar. Quando eu cheguei na sala, tive uma surpresa, tinha língua de sinais, havia uma intérprete que traduzia a aula do professor. Eu fiquei admirada, consegui compreender melhor os conteúdos de matemática, português, inglês, eu gostei muito, fiquei muito interessada em aprender, passei a gostar muito de estudar. Eu peço ajuda aos professores e eles me auxiliam, falam pra mim que eu sou inteligente, contudo eu explico que eu já fiz o ensino médio, mas que eu tenho muita vontade de aprender mais, isso porque depois de estudar bastante eu tenho vontade de fazer um curso tecnólogo de segurança do trabalho, eu quero, tenho muita vontade. Os professores sabendo disso, tem me incentivado bastante. Assim, tenho caminhado passo a passo e em novembro quando o módulo 
acabar eu gostaria de procurar um lugar para continuar a estudar, mas onde tem intérpretes? Eu fico pensando se terei recursos, em qual escola estudar. Ai, eu fui conversar com a intérprete da fábrica e ela me explicou que existem várias instituições conveniadas que podem me garantir isso, Eu fiquei muito aliviada. Eu gostei muito de voltar a estudar, os surdos precisam ter coragem, não devem abaixar suas cabeças, pensando que os ouvintes são superiores, pelo contrário, surdos e ouvintes possuem capacidade para conseguir o que almejam. Os surdos precisam esperar mudanças para o seu futuro, melhores formações, melhores salários. Não devem parar de estudar e se apoiarem na condição de deficiente, pois os surdos são normais, assim como os ouvintes. Os surdos de todo o Brasil precisam desta perspectiva. Hoje eu sou muito feliz estudando com a interpretação em LIBRAS nas aulas. Graças a Deus.

Retomando o ponto do depoimento de Maria, sobre o fato dela já possuir o ensino médio e mesmo assim, estar repetindo o processo, isso tem relação a uma leitura que ela faz, quando no passado, por não ter tido acesso aos conteúdos na íntegra, ela aprendeu pouco. Sabemos que há alguns anos atrás por conta da falta de estrutura as escolas não possuíam intérpretes de língua de sinais e profissionais qualificados, assim, ela não teve nenhum intérprete para traduzir o que era dado na sala de aula.

Por esse motivo, ela entende que é necessário aprender mais e matricular-se na EJA da Garoto, mesmo sem precisar, objetivando melhorar o seu padrão acadêmico, pode contribuir para que, no futuro, ela possa tentar o curso técnico e superior.

Dando continuidade, além de Maria, outros surdos também demonstraram o desejo em dar continuidade aos estudos em outros níveis. Esta é uma constatação interessante, levando em consideração que muitos nos revelaram ter o interesse em apenas concluir o ensino médio. Assim, é de suma importância destacar que existe uma contrapartida, e que muitos estão em um movimento de buscar formação para o mundo do trabalho. 
Deste modo, destacamos também a fala de Mário, um surdo que veio de um outro estado em busca de trabalho e que aqui chegando, encontra oportunidade de emprego na fábrica da Chocolates Garoto. Sua trajetória é um tanto interessante, pois ele também é um estudante que veio do INES, ou seja, já tinha uma convivência com a língua de sinais.

Eu estudei todo o meu ensino fundamental e médio no INES. Quando terminei, estava de férias da escola, mas trabalhando em uma empresa, quando de repente fui demitido, devido a problemas na empresa. Fiquei muito triste e voltei para casa. Depois disso, meu amigo André veio a minha casa e me convidou para mudar para Vitória, para vir trabalhar em uma fábrica de chocolates. Eu pensei, conversei com a minha mãe, ela me incentivou, eu arrumei as minhas coisas e vim para Vitória. Cheguei aqui, não conhecia ninguém, com o passar tempo, conheci alguns surdos, fiquei aqui um tempo, depois fui ao Rio de Janeiro visitar minha família. Quando voltei, aluguei uma casa aqui em Vitória e comecei a trabalhar na fábrica de chocolates.

Depois de um tempo, vários surdos vieram me chamar para voltar a estudar na sala de EJA da fábrica, a princípio eu fiquei resistente, não quis, mas os surdos me incentivaram, me dizendo que voltar a estudar me daria uma projeção para uma possível faculdade no futuro. Eu pensei, pensei e decidi aceitar. Fui até a intérprete da fábrica e disse que eu gostaria de voltar a estudar. Comecei a estudar, gostei muito, na sala tem intérprete de LIBRAS. No futuro, eu pretendo fazer uma faculdade. Ter voltado a estudar fez com que eu me sentisse muito bem. Mas, eu fiquei triste que muitos surdos desistiram e o número de alunos da sala diminuiu, eu sei que cada um tem os seus problemas particulares, eu respeito, mas eu vou continuar a seguir o caminho dos meus estudos.

Um outro estudante que também nos revelou esta intenção, foi Paulo. O caso dele especificamente é muito interessante porque ele chega para trabalhar na fábrica conhecendo apenas o básico da língua de sinais. Ele nos conta a sua trajetória de forma interessante.

Meu nome é Paulo, este é meu nome visual. Eu nasci em 
Colatina e mudei junto com minha família para Vitória porque onde eu morava não tinha escola para surdos. Assim, comecei a estudar na escola de surdos de Vitória. Lá eu comecei a aprender língua de sinais com os outros surdos. Mas, a escola era longe da minha casa, eu ficava muito cansado, então, mudei para uma escola de ouvintes perto da minha casa. Eu ia para as aulas, mas eu não entendia nada, porque as pessoas só conversavam oralmente. Ficava sozinho, tinha muita vergonha, as pessoas me ofereciam ajuda, mas eu não entendia, então ficava sentado sozinho, tentando entender. Eu sofria muito, estava com 10 anos, mas eu continuei a tentar e consegui evoluir em alguns aspectos. Com a idade de 17 anos, eu ainda tentava aprender algumas coisas, a partir de um esforço individual, , porque eu não tinha intérprete e as pessoas só falavam oralmente ao meu redor. Aprendi muitas coisas sozinho: matemática e português, com o tempo, minha cabeça se abriu para algumas coisas.

Depois de um tempo, ligaram para minha casa e disseram que havia vagas para surdos na Garoto. Consegui passar no processo seletivo. Lá, passei a gostar do meu trabalho, da interação em língua de sinais com os meus colegas. Depois de um tempo, me falaram sobre a importância de estudar e que a fábrica estava organizando duas turmas de ensino fundamental e médio. Eu entendi que precisava voltar a estudar e aceitei entrar. Chegando, percebi que as aulas eram traduzidas, achei isso muito legal, me senti emocionado, porque pela primeira vez eu conseguia compreender o que me ensinavam de forma clara. No futuro eu pretendo fazer uma faculdade ou um curso técnico.

Fica claro no depoimento de Paulo as questões por ele enfrentadas: solidão, dificuldades de aprendizagem e comunicação. Entretanto, ele se mostra aberto a nova experiência de trabalhar em uma fábrica onde seus colegas de trabalho são surdos, inclusive, ele demonstra em sua fala que se sente bem em interagir através da língua de sinais e de estudar em um ambiente que o favorece nesse quesito.

O que Paulo vivenciou através da sua entrada na fábrica é o que Bakhtin (2010c) aponta como sendo o confronto entre dois mundos - o mundo da cultura e o mundo da vida, no sentido de que antes incomunicáveis e mutuamente impenetráveis, a partir desse encontro, é onde as coisas irrepetivelmente ocorrem. (p.43) 
Nesse sentido, também podemos compreender o espaço da EJA da Garoto como um espaço de sociabilidade entre os educandos surdos, um momento onde os surdos que sinalizam podem auxiliar àqueles que ainda estão conhecendo a língua de sinais de forma tímida e projetando seus planos para o futuro.

Uma outra coisa muito importante que observamos foi que, quando chegamos ao espaço da EJA da Garoto, quando fizemos a primeira conversa, foi possível constatar que muitos surdos tinham essa ideia de continuar a estudar, contudo, a maioria deles não sabia em quais escolas eles poderiam tentar, que os surdos também podem fazer cursos técnicos e superior.

No momento em que foram socializados os sites das instituições com eles, ficou evidente o desconhecimento dos surdos em relação a estas escolas e seus cursos. Este fato evidencia a falta de informação que o surdo tem, devido as barreiras linguísticas. Assim, como os surdos conseguirão chegar ao Ifes, tentar a prova de seleção, se a informação sobre os cursos não chegam a eles ? Aqui chegamos a um ponto onde fica claro que não bastam as ações internas nas escolas, pois os surdos estão na sociedade e precisam de informação.

O que nos motivou trazer o exemplo deste trabalho foi 0 fato de que compreendemos que ambas as experiências, tanto a do Ifes, como a da EJA da Garoto, são exemplos de caminhos possíveis para a formação do surdo trabalhador. Assim, cabem aqui algumas reflexões necessárias e urgentes.

O primeiro ponto que gostaríamos de abordar está ligado ao retorno à escola. Esse movimento se dá por um conjunto de exclusões sociais que estes educandos surdos viveram ao longo de suas trajetórias estudantis. Sabemos que hoje existem movimentos em todos os setores da sociedade em prol da inclusão, no entanto, a lógica da exclusão ainda é presente em vários setores da sociedade. E essa resistência em incluir, em termos liberdade em relação as nossas concepções e 
nossa alteridade, de modo geral, afeta vários grupos sociais, dentre eles, os surdos. Sobre isso, Geraldi (2007) nos aponta que

\footnotetext{
Depredação e recusa na relação com a alteridade produziram desigualdades, e muitas das que denominamos "diferenças sociais" são produções destas desigualdades, já que diferenças apenas podem emergir entre semelhantes ou entre iguais. (p.50)
}

O fato de historicamente os surdos e os demais grupos socialmente excluídos não terem sido tratados como iguais, gerou todo esse passado excludente e até hoje, essas desigualdades, são arrastadas como correntes pesadas, arranhando os pisos e produzindo um barulho que ecoa através dos tempos .

Assim, como vamos construir um futuro que seja distinto ao passado que excluiu essas pessoas, privando-as de serem iguais, no sentido do direito e da cidadania?

Não objetivamos fazer previsões, contudo, no pensamento bakhtiniano existe a ideia de que "no mundo da vida calculamos, a todo instantes, com base na memória do futuro desejado, as possibilidades de ação no presente" (Geraldi, 2007, p.50). Assim, não podemos deixar de nos preocupar o que o futuro reserva a esses surdos, enquanto estudantes e sua permanência no mundo do trabalho.

O fato é que em nosso trabalho, registramos algumas possibilidades que construíram outros caminhos possíveis para que os surdos estudem e alcancem outros níveis de ensino, em nosso caso especificamente o ensino profissionalizante. No entanto, são possíveis outras ações que segundo Geraldi, precisamos nos preocupar em "calcular".

Deste modo, não podemos deixar de nos preocupar ou de pensar que talvez os surdos não alcancem determinado espaço e que por isso, a acessibilidade não deve estar presente ali, ou que as políticas bilíngues não devam ser implementadas em dadas situações porque não existem estudantes surdos naquele espaço. Ao contrário disso, só poderemos vislumbrar os educandos surdos ocupando os 
espaços depois que essas condições forem estabelecidas. Geraldi (2007) faz uma reflexão que complementa o nosso pensamento sobre projetarmos as ações para uma dimensão futura, o autor nos diz que

\footnotetext{
Trata-se de pensar que a todo momento, a todo acontecimento, o futuro é repensado, refeito e deste lugar desterritorializado, sempre mutável, o sujeito se situa para analisar o presente vivido e, nos limites de suas condições e dos instrumentos disponíveis, construídos pela herança cultural e reconstruídos, modificados, abandonados, ou recriados pelo presente, uma das possibilidades de ação é selecionada. (p.51)
}

Assim, esta preocupação deve estar presente nas políticas, pois tudo o que construímos e pensamos está em uma dimensão histórica, que acompanha não só os limites temporais, como também os acontecimentos políticos e sociais. Assim, a preocupação com a consolidação das políticas bilíngues, o acesso e a permanência dos surdos na escola, deve ser uma questão presente em nossas articulações dentro do espaço da educação. 


\section{CONSIDERAÇÕES FINAIS}

Retomando nossa discussão inicial, sobre a história dos surdos, percebemos que com o passar dos anos, muitos pontos foram sendo agregados ao percurso das práticas educativas que envolvem esses sujeitos. Contudo, percebemos que muitas questões ainda ecoam sem resposta dentro do universo que é a educação de surdos.

O que Coelho (2007) apontou em sua tese sobre os "banquetes surdos" e a existência de um grupo de surdos, articulados filosoficamente em suas concepções de mundo, deixa-nos um tanto apreensivos sobre o futuro dos surdos contemporâneos e a pergunta é : será que na atualidade esses grupos de surdos intelectualizados, escolarizados e articulados terão condições de emergir diante do processo educativo no qual esses surdos encontram-se hoje?

Essa questão tem sido uma grande preocupação no cenário educacional onde encontramos os surdos, isso porque, segundo o percurso histórico apresentado neste trabalho, apesar da presença de outras metodologias de ensino para surdos serem aplicadas hoje, eles não têm conseguido alcançar elevados níveis de escolarização, devido aos entraves existentes, princialmente no quesito acessibilidade, apesar da lei de LIBRAS 10436/02 e do Decreto 5626/05.

Sabemos da questão do direito a acessibilidade, inclusive, este também foi um ponto problematizado neste trabalho, quando evidenciamos que tudo parte, primordialmente, do direito a educação e dos compromissos firmados pelo Brasil nos acordos internacionais em prol da educação.

A maior prova dessa preocupação emerge dentro da própria comunidade surda, quando esta se movimentou em todo o país, buscando implementar as escolas bilíngues para surdos, como forma de responder as questões linguísticas desse grupo, no movimento do Setembro Azul de 2011 em nome das escolas bilíngues. 
Após esse movimento, algumas respostas já foram alcançadas, como a publicação do Decreto 7611/11 que revogou o Decreto 6571/08, garantindo aos surdos as observações sobre suas questões a partir do Decreto 5626/05, o que de uma certa forma, foi um benefício, levando em conta que o decreto traz balizamentos acerca das escolas bilíngues e seus respectivos detalhes, tais como os profissionais envolvidos, o uso e difusão da LIBRAS, da formação dos profissionais, dentre outros aspectos.

Então, quando narramos o processo de inclusão dos estudantes surdos dentro do Ifes, nós partimos de um cenário contemporâneo que tem trazido algumas contribuições importantes para a educação de surdos, mas que ainda não são suficientes para sanar as questões referentes a acessibilidade e a formação dos sujeitos surdos.

Atualmente, ainda identificamos muitos surdos adultos que não conseguiram concluir os seus estudos, por conta disso, muitos deles encontram dificuldades para inserir-se no mundo do trabalho. Assim, pensamos que o processo vivenciado pelos estudantes surdos apontados neste trabalho, poderia ser uma saída para atender a essas demandas. Afinal, esses sujeitos já encontram-se nessa situação e infelizmente, a maioria das ações organizadas pelas políticas educacionais, tem se concentrado no ensino básico regular. Por isso, discutimos essa questão da formação do surdo trabalhador dentro da perspectiva da EJA e da EPT.

A primeira delas que queremos destacar é o acesso dos surdos ao espaço escolar, pois os surdos que ingressaram no Ifes chegaram aquele espaço através de processo seletivo e tiveram muitas dificuldades em permanecer no espaço escolar dessa instituição.

Contudo, cabe ressaltar que muitos esforços foram feitos pelo Ifes para atender as demandas dos surdos, tais como a monitoria, a contratação de intérpretes, olhares diferenciados sobre as avaliações dos educandos. Só que essas estratégias 
respondem apenas as questões relacionadas aos conteúdos ministrados nas aulas e a acessibilidade dos estudantes.

Os demais aspectos relacionados ao fato da língua de sinais ser uma língua corrente naquele espaço, a presença de outros surdos na escola, a fim de responder as questões sociais de interação dos educandos formaram uma lacuna e não foram alcançados, apesar dos esforços. Compreendemos que isso tem relação com outras questões, pois para que isso acontecesse, seria necessário construir um espaço bilíngue para os surdos no lfes e que outros surdos entrassem na instituição.

A EJA da Garoto também não é um espaço bilíngue, no sentido da metodologia de trabalho, pois o que os profissionais ali desenvolvem tem relação com adaptações de materiais e traduções das aulas, mas o que favorece este ambiente são as relações tecidas no cotidiano dos surdos entre os surdos.

O fato da presença de muitos surdos corrobora com a circulação do conhecimento entre os educandos, construindo assim, dialogicamente, os processos de aprendizagem. Por isso, trouxemos este exemplo, para que possamos compreender que os surdos dialogam com os seus pares.

Para além disso, também devemos considerar que os surdos que passaram pelo Ifes e os que se encontram hoje na EJA da Garoto, projetaram para si outras possibilidades, com a finalidade de construir um futuro no qual eles possam passar por um processo de formação que os capacite. Talvez seria o caso de tentar articular uma Pedagogia Bilíngue com o desenvolvimento tecnológico, e para isso, muitas coisas deveriam ser revistas.

Assim, quando pensamos na questão do surdo no mundo do trabalho, nós precisamos compreender quais são as teorias que estão articulando isso, pois se estivermos pensando tudo isso numa perspectiva mecanicista, onde o surdo é visto pelo viés da deficiência, nós deixamos de compreender este sujeito como um ser de 
capacidade e passamos a construí-lo pelo viés da incapacidade. E a incapacidade no sistema capitalista, significa um ser não produtivo. Assim, os investimentos educacionais movidos nesse sentido, acabam por se esvair ou não conseguem alcançar os objetivos de formação e inserção desses sujeitos no mundo do trabalho.

Percebemos aqui que antes de qualquer coisa, devemos apurar o nosso olhar sobre esse sujeito, pensar o surdo pela sua diferença linguística, para ai sim, podermos desenvolver políticas educacionais que atendam as suas demandas, pois muitas vezes, só as adequações não bastam, precisamos ir além, para atender não só o quesito acessibilidade, mas garantir também a presença da cultura surda e seus artefatos como parte do universo escolar e pensar tudo isso dentro do processo de inclusão desses educandos.

Pois só garantir o acesso através de intérpretes de língua de sinais não é o suficiente para este educando surdo, que chega para nós cheio de lacunas na sua formação estudantil. São necessárias outras atitudes, como por exemplo, pensar uma forma de aglutinar os surdos em um mesmo local, promover os exames do processo seletivo que garanta os direitos dos surdos, para que assim, mais surdos consigam entrar no Ifes e em outros espaços educacionais.

E por último, sinalizamos a importância da formação dos professores, pois estes são a chave para o desenvolvimento do trabalho em sala, de modo que estes tenham conhecimento acerca da singularidade linguística do seu educando surdo, não só para a comunicação, como também para a preparação das aulas e avaliações.

Acreditamos que os movimentos sociais surdos tendem a alcançar muitas conquistas em futuro próximo, contudo, é necessário que os sujeitos surdos da EJA não sejam esquecidos, afinal, eles já se encontram no mundo do trabalho e necessitam de formação para permanecer e construir a sua subsistência enquanto trabalhadores que são. 
Resgatar esses percursos dos estudantes surdos no Ifes, na EJA e tudo que está relacionado a isso é fazer uma reflexão sobre os fatos para essa história não se perca, as ciências humanas tem o comprometimento de preservar essa memória, pois muito temos a aprender com as pessoas que viveram este processo.

Kramer (2007) sinaliza a importância de sempre lembrarmos as experiências passadas, como sendo fonte de aprendizado e memória, o compromisso de se resgatar narrativas e histórias "é o de encontrar aquilo que se perde quando o homem é transformado em objeto e as histórias das pessoas são esquecidas” (p.58)

Pensar nesta dimensão é compreender que os processos históricos se dão alheios a nossa vontade e que cabe a nós a busca pelo entendimento dos mesmos, a fim de encontrarmos outros atalhos para chegarmos onde objetivamos.

Neste sentido, ao caminharmos em direção ao que a história tem a nos mostrar, temos a oportunidade de perceber, nas falas dos que se dispõe a nos contar um pouco sobre as suas trajetórias, o ato de reconstrução dos fatos passados e dos sujeitos ocupando, cada qual o seu lugar. Segundo Kramer, "histórias de vida são consideradas como memória coletiva do passado, consciência crítica do presente e premissa operativa do futuro" (p.58)

A partir dessa reflexão, compreendemos que este resgate da memória tende a nos auxiliar na compreensão do nosso cotidiano e assim, encontrar algumas respostas para as questões postas. A nossa experiência com o passado traz inúmeros indícios que nos sugerem a compreender que os mecanismos criados para atender os surdos nas escolas não foram de encontro ao que os surdos almejavam e com isso, muitos deles ficaram excluídos do processo de escolarização.

Não podemos dar as costas ao que os narradores apontaram de forma tão pontual sobre como no início as coisas eram difíceis e que com o passar do tempo e o avanço das ações, elas foram melhorando. Essas pistas são deixadas pela 
experiência. Sobre isso, Kramer (2007) nos diz que

\begin{abstract}
Resgatar o passado significa ter uma compreensão diferente da história; o passado é importante para rever o presente, para colocá-lo numa dimensão crítica, conferir-lhe nova significação. E a história humana é baseada nesta descontinuidade; somente os seres humanos tem histórias e por isso a linguagem é necessária. Como o homem é gerado na cultura, ele pode fazer história e contar história. (p.58)
\end{abstract}

Pensando sobre o que a autora nos diz, é fundamental conhecermos estes fatos históricos e tentar fazer um exercício de trazer essas informação para o debate, para que essas reflexões não caiam no vazio.

Pois se existem alguns espaços onde as transformações foram possíveis, devemos trabalhar para que essas mudanças possam chegar para todos os estudantes surdos em todos os níveis de ensino.

E por último, compreendermos que a história é construída por todos nós e nela temos a oportunidade de desvelar os acontecimentos passados e pensar em outras saídas para os dilemas no futuro, tentar construir algo novo, que possa atender os surdos como eles almejam. Assim, encerramos com as palavras de Freire (2000), quando o autor diz que " que não é porém possível sequer pensar em transformar o mundo sem sonho, sem utopia ou sem projeto". (p.53) 


\section{REFERÊNCIAS BIBLIOGRÁFICAS}

ABDALA JÚNIOR, Benjamin. Um ensaio de abertura: mestiçagem, hibridismo, globalização e comunitarismo. In: ABDALA JÚNIOR, Benjamin.(org).Margens da Cultura: mestiçagem, hibridismo \& outras misturas. São Paulo: Boitempo, 2004, p.09-20

AMORIM, Marília. A contribuição de Mikhail Bakhtin: a tripla articulação ética, estética e epistemológica. In: FREITAS, Maria Teresa, et al. (orgs). Ciências humanas e pesquisa: Leituras de Mikhail Bakhtin. São Paulo: Cortez, 2007, $2^{\mathrm{a}}$ ed., p. $11-25$.

BAKHTIN, M.(V. N. Volochínov). Marxismo e Filosofia da Linguagem. São Paulo: Hucitec, 2006.

BAKHTIN, Mikhail Mikhalovitch. Estética da criação verbal. São Paulo: Editora WMF Martins Fontes, 2010a, 5 ${ }^{\mathrm{a}}$ ed.

Problemas da poética de Dostoiévski. Rio de Janeiro: Forense Universitária, 2010b, 5ª ed.

Carlos: Pedro \& João Editores. 2010c.

Para uma filosofia do ato responsável. São

BENJAMIN, WALTER. O Narrador. Considerações sobre o obra de Nikolai Leskov. In: BENJAMIN, Walter (org). Magia e Técnica, arte e política: ensaios sobre literatura e história da cultura. São Paulo: Brasiliense, 1994, p.197-232.

Cidades; Ed 34, 2011, p.101-121

. Escritos sobre mito e linguagem. São Paulo: Duas

BENVENUTO, Andrea. O Surdo e o inaudito. À escuta de Michel Foucault. In: KOHAN, Walter; GONDRA, José (orgs). Foucault 80 anos. Belo Horizonte: Autêntica, 2006, p.227-246.

BIANCHETTI, Lucídio, CORREIA, José Alberto. In/Exclusão no trabalho e na Educação: aspectos mitológicos, históricos e conceituais. Campinas, SP: 
Papirus, 2011.

BRAIT, Beth. Bakhtin: Conceitos Chaves. São Paulo - Conceito, 2010.

BRASIL. Congresso Nacional. Constituição da República Federativa do Brasil. Artigo 205, p. 123, 2002.

BRASIL. Lei no $\mathbf{1 0 . 4 3 6}$ de 24 de abril de 2002. Dispõe sobre a Língua de Sinais - e dá outras providências. Disponível em www.planalto.gov.br/ccivil_03/Leis/2002/L10436.htm>. Acesso em 03 de maio de 2011.

BRASIL. Decreto no 5.626. Regulamenta a Lei 10.436 de 24 de abril de 2002, que dispõe sobre a Língua de Sinais - LIBRAS e o art. Da lei no 10.098, de 19 de dezembro de 2000. Publicada no Diário Oficial da União em 22/12/2005. Disponível em www.planalto.gov.br/ccivil_03/_ato2004-2006/2005/decreto/d5626.htm. Acesso em 05 de maio de 201.

BRASII. Decreto no 7611, de 17 de novembro de 2011, disponível em: www.planalto.gov.br/ccivll_03/_Ato2011.../Decreto/D7611.htm, acesso em 23/ 05/2012, às 23:45h.

BRASIL. Decreto no 6571, de 17 de setembro de 2008, disponível em: www.planalto.gov.br/ccivil_03/_...2010/2008/Decreto/D6571.htm, acesso em 24/05/2012, às 13:24h.

BRASIL. Lei de Diretrizes e Bases da Educação Nacional (LDBEN) nª 9394/96, disponível em: www.planalto.gov.br/ccivil_03/leis/L9394.htm, acesso em 13/05/2012, às 13:30h.

CAGGIANO, Mônica Herman S. A Educação: Direito Fundamental. In: RANIERE, N. B. S., RIGHETTI, S. (orgs). Direito à Educação. São Paulo: EDUSP, 2009, p. 19 -38 .

CANCLINI, Nestor García. Diferentes, desiguais e desconectados. Rio de Janeiro: Editora da UFRJ, 2007, 2ª ed., p. 15 - 54 
COELHO, Orquídea Manuela Braga e Soares. Construindo Carreiras: (Re) Desenhar o percurso educativo dos surdos a partir de modelos bilíngues. Tese de Doutorado. Faculdade de psicologia e de Ciência da Educação - U. Porto - Julho de 2007.

COUTO-LENZI, Álpia. Cinquenta Anos: uma parte da história da educação de surdos. Vitória: AIPEDA, 2004.

Declaração de Cochabamba: Educação para todos - cumprindo nossos compromissos coletivos. Cochabamba / Bolívia, 05 a 07 de março de 2001. Disponível em: www.unesco.org/new/pt/brasilia. Acessado em 01/10/2011, às 18:00h.

Declaração Mundial sobre Educação para Todos e Plano de Ação para Satisfazer as Necessidades Básicas de Aprendizagem. Aprovada pela Conferência Mundial sobre Educação para Todos: Satisfação das Necessidades Básicas de Aprendizagem Jomtien, Tailândia - 5 a 9 de março de 1990. Disponível em: www.acaoeducativa.org.br/downloads/Declaracao_Jomtien.pdf, acessado em 01/10/2011, às 16:50 h.

D'ANGELO, Martha. Arte, política e Educação em Walter Benjamin. São Paulo: Edições Loyola, 2006.

Declaração Mundial sobre Educação para Todos: o Compromisso de Dakar. Fórum Mundial de Educação, Dakar - Senegal, 26 a 28 de abril de 2000. Disponível em: www.unesco.org/new/pt/brasilia. Acessado em 01/10/2011, às 17:20h.

Documento do MEC: Trabalhando com educação de Jovens e Adultos: alunos e alunas da EJA. Brasília, 2006, disponível em:www. portal.mec.gov.br/secad/arquivos/pdf/eja_caderno1.pdf, acessado em 05/09/2012, as 13:45h.

FIORI, Ernani Maria. Aprender a dizer a sua palavra. In: FREIRE, Paulo. Pedagogia do Oprimido, Rio de Janeiro, Paz e Terra, 2005, p.07-22.

FIORIN, José Luiz. Introdução ao pensamento de Bakhtin. São Paulo: Ática, 2008, p. 18-76. 
FREIRE, Paulo. Pedagogia do Oprimido, Rio de Janeiro, Paz e Terra, 2005.

.Pedagogia da Autonomia: saberes necessários à prática educativa. São Paulo: Paz e Terra, 1996, p. 91-148.

Pedagogia da Indignação. São Paulo: UNESP, 2000

Extensão ou Comunicação? Rio de Janeiro: Paz e Terra, 1983, 8ª

ed.

FREITAS, Maria Teresa. A perspectiva sócio-histórica: uma visão humana da construção do conhecimento. In: FREITAS, Maria Teresa, et al. (orgs). Ciências humanas e pesquisa: Leituras de Mikhail Bakhtin. São Paulo: Cortez, 2007, $2^{\underline{a}}$ ed., p. $26-38$.

GERALDI, João Wanderley. A diferença identifica. A desigualdade deforma. Percursos bakhtinianos de construção ética e estética. In: FREITAS, Maria Teresa, et al. (orgs). Ciências humanas e pesquisa: Leituras de Mikhail Bakhtin. São Paulo: Cortez, 2007, 2ª ed., p. $39-56$

GIORDANI, Liliane Ferrari. Educação de Surdos: políticas públicas no diálogo com a comunidade. In: THOMA, Adriana da Silva e LOPES, Maura Corcini (orgs). A Invenção da Surdez II. Santa Cruz do Sul: EDUNISC, 2006, p. 117-124..

GIORDANI, Liliane Ferrari. Educação Inclusiva na Educação de surdos: o que se permite entre a política oficial e o movimento social. In: VIEIRA-MACHADO, Lucyenne Matos da Costa e LOPES, Maura Corcini. Educação de surdos: políticas, língua de sinais, comunidade e cultura surda. Santa Cruz do Sul: EDUNISC, 2010.

HALL, Stuart. Identidade cultural na pós-modernidade. Trad: SILVA, Tomás Tadeu; LOURO, Guacira Lopes. Rio de Janeiro: DP\&A, 2006, 11ํed.

HOBSBAWM, Eric.A História de baixo para cima. In: HOBSBAWM, Eric. Sobre a História. São Paulo: Companhia das Letras. 1998, p.216-231 
KRAMER, Sônia, Entrevistas coletivas: uma alternativa para lidar com diversidade, hierarquia e poder na pesquisa em ciências humanas. In: In: FREITAS, Maria Teresa, et al. (orgs). Ciências humanas e pesquisa: Leituras de Mikhail Bakhtin. São Paulo: Cortez, 2007, 2ª ed., p. 57-76

LACERDA, Cristina Broglia. Intérprete de LIBRAS: em atuação na educação infantil e no ensino fundamental. Porto Alegre: Mediação, 2009.

LEBEDEFF, Tatiana Bolivar. O que lembram os surdos de sua escola: discussão das marcas criadas pelo processo de escolarização. In: Adriana da Silva e LOPES, Maura Corcini (orgs). A Invenção da Surdez II Santa Cruz do Sul: EDUNISC, 2006, p. 47-62.

LE GOFF, Jacques. Prefácio. In: BLOCH, Marc. Apologia da História ou o Ofício de Historiador. Rio de Janeiro: Jorge Zahar Ed., 2001, p. 07-38.

MARQUES, Rodrigo Rosso. Educação de Jovens e Adultos: um diálogo sobre a educação e o aluno surdo. In: QUADROS, Ronice Muller de \& PERLIN, Gladis (orgs). Estudos Surdos II. Petropólis / RJ: Editora Arara Azul, 2007, p.132-149.

MARX, Karl. Para a Crítica da Economia Política - manuscrito de 1861-1863 cadernos de I a V- Terceiro capítulo - O capital em geral. Belo Horizonte: Autêntica Editora, 2010, p. 21-100

MONTEIRO, Myrna Salerno. História dos movimentos surdos e o reconhecimento da LIBRAS no Brasil. Disponível em http://www.fae.unicamp.br/revista/index.php/etd/article/view/1649, acessado em 12 de junho de 2012, às 22:40h.

O INES E A EDUCAÇÃO DE SURDOS NO BRASIL. Vol. 1, 2ª edição (DEZ/2008) Rio de Janeiro: INES / 2008.

OLIVEIRA, Bernardo Barros Coelho de. Olhar e narrativa: leituras benjaminianas. Vitória: Edufes, 2006, p.57-90 
PEREIRA, Marina Lúcia. A construção do letramento na educação de jovens e adultos. Belo Horizonte: Autêntica, 2007.

PROPOSTA DE EMENDAS SUBSTITUTIVAS AO PROJETO DE LEI N. 8.035, DE 2010 - PLANO NACIONAL DE EDUCAÇÃO (PNE) 2011-2020. Disponível em: www.feneis.com.br/setembroazul, acessado em 01/10/2011, às 14:32 h.

RANIERE, Nina Beatriz Stocco. Os Estados e o direito à educação na Constituição de 1988: comentários acerca da jurisprudência do Supremo Tribunal Federal. In: RANIERE, N. B. S., RIGHETTI, S. (orgs). Direito à Educação. São Paulo: EDUSP, 2009, p. $39-60$.

RECOMENDAÇÕES Segundo Congresso Internacional sobre Ensino técnico e profissional $26-30$ abril 1999. Seul, República da Coréia. Disponível em: www.unesco.org/new/pt/brasilia. Acessado em 01/10/2011, às 16:50h.

RICOUER, Paul. Sobre a tradução. Belo Horizonte: Editora da UFMG, 2011.

Tempo e narrativa. Campinas: Papirus, 1997.

ROCHA, Solange. O INES e a Educação de surdos no Brasil. Vol. 01, 2ª edição Rio de Janeiro: INES/2008

SÁCKS, Oliver. Vendo Vozes: uma viagem ao mundo dos surdos. Tradução Laura Teixeira Motta - São Paulo: Companhia das Letras, 1998.

SANTOS, Boaventura de Sousa. A gramática do tempo: para uma nova cultura política. São Paulo: Cortez, 2006, p.100-316

SANTOS, Geovania Lúcia Silva Almeida. Quando adultos voltam para a escola: o delicado equilíbrio para obter êxito na tentativa de elevação da escolaridade. In: SOARES, Leôncio. Aprendendo com a diferença - estudos e pesquisas em Educação de Jovens e Adultos. Belo Horizonte: Autêntica, 2006, 2 ed., p. 11-38. 
SILVA, Tomaz Tadeu. A produção social da identidade e da diferença. In:SILVA, Tomaz Tadeu.(org).Identidade e diferença: a perspectiva dos estudos culturais. Petrópolis: Vozes, 2000. p.73-102

SKLIAR, Carlos. Prefácio. A Pergunta pelo outro da língua; a pergunta pelo mesmo da língua. In: LODI, Ana Claúdia; HARRISON, Kathry M. P.; CAMPOS, Sandra e TESKE, Otmar (orgs). Letramento e Minorias. Porto Alegre: Mediação, 2002, p. 05-12.

TESKE, Otmar. Letramento e minorias numa perspectiva das Ciências Sociais. In: LODI, Ana Claúdia; HARRISON, Kathry M. P.; CAMPOS, Sandra e TESKE, Otmar (orgs). Letramento e Minorias. Porto Alegre: Mediação, 2002, p.144-160

A relação dialógica como pressuposto na aceitação das diferenças: o processo de formação das comunidades surdas. In: SKLIAR, Carlos (org). A surdez: um olhar sobre as diferenças. Porto Alegre: Mediação, 2005.

THOMA, Adriana da Silva. Identidade e diferença surda constituídas pela avaliação. In: THOMA, Adriana da Silva, KLEIN, Madalena (orgs). Currículo e Avaliação: a diferença surda na escola. Santa Cruz do Sul: EDUNISC, 2009, p.49 $-68$

THOMA, Adriana da Silva, KRAEMER, Graciela Morjana. Identidade e diferenças produzidas no campo da educação de surdos. In: Silva, Mozart Linhares, et al. (orgs) Estudos Culturais, Educação e Alteridade. Santa Cruz do Sul: EDUNISC, 2009, p.257 - 272 .

VIEIRA-MACHADO, Lucyenne Matos da Costa. Os surdos, os ouvintes e a escola: narrativas, traduções e histórias capixabas. Vitória: EDUFES, 2010.

YAGUELLO, Marina. Introdução. In: Bakhtin, Mikhail. Marxismo e Filosofia da Linguagem. São Paulo: HUCITEC, 2006, p. 12-20.

ZITKOSKI, Jaime José. Paulo Freire \& a Educação. 2a ed. Belo Horizonte: Autêntica Editora, 2010. 
ZITKOSKI, Jaime José. Dialogicidade In: STRECK, Danilo R.; REDIN, Euclides; ZITKOSKI, Jaime José (orgs). Dicionário Paulo Freire. 2. ed. rev. amp. - Belo Horizonte: Autêntica Editora, 2010, p117-118. 